\title{
Zlíchovian faunas with early ammonoids from Morocco and their use for the correlation of the eastern Anti-Atlas and the western Dra Valley
}

\author{
KenNeth De Baets, Christian KLUG \& YVES PlusquelleC
}

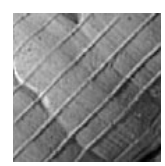

\begin{abstract}
Two sections were sampled and measured at Mdâour-El-Kbîr (Dra Valley, western Anti-Atlas) and at eastern Ouidane Chebbi (Tafilalt, eastern Anti-Atlas). In situ elements of two partially limonitized and one carbonatic fauna were found in both sections. We report this fauna from the upper Merzâ-Akhsaï Formation and the lower Mdâour-el-Kbîr Formation at Mdâour-el-Kbîr for the first time. Based on these faunas, we recorded a correlation of the early Emsian (Zlíchovian) strata in the Tafilalt and the Dra Valley regions, which are about $350 \mathrm{~km}$ apart. Additionally, new ammonoid finds (Teicherticeras cf. senior, Lenzites gesinae, Weyeroceras angustus) are figured and described including the stratigraphic context. The diagnoses of Lenzites gesinae and Weyeroceras angustus are emended. Tabulate corals (Michelinia mdaourensis sp. nov., Petridictyum sp.) found in both the Tafilalt and Dra Valley are figured and described for the first time. $•$ Key words: early Emsian, Ammonoidea, Tabulata, Micheliniidae, biostratigraphy, Anti-Atlas, Morocco.
\end{abstract}

DE BAETS, K., KLUG, C. \& PlusquelleC, Y. 2010. Zlíchovian faunas with early ammonoids from Morocco and their use for the correlation of the eastern Anti-Atlas and the western Dra Valley. Bulletin of Geosciences 85(2), 317-352 (16 figures, 2 tables). Czech Geological Survey, Prague. ISSN 1214-1119. Manuscript received December 26, 2009; accepted in revised form May 19, 2010; published online June 23, 2010; issued June 30, 2010.

Kenneth De Baets \& Christian Klug, Paläontologisches Institut und Museum, Universität Zürich, Karl Schmid-Strasse 4, 8006 Zürich, Switzerland; kenneth.debaets@pim.uzh.ch, chklug@pim.uzh.ch・Yves Plusquellec, Laboratoire de Paléontologie (UMR 6538 Domaines Océaniques), Université de Bretagne Occidentale, UFR Sciences et Techniques, 6 avenue Le Gorgeu, 29238 Brest Cedex 3 - France; Yves.Plusquellec@univ-brest.fr

The Devonian of the Anti-Atlas is known for its excellent outcrops and large number of well-preserved fossils, especially in the eastern Anti-Atlas. Recently, Klug et al. (2008) described two distinct, rather rich early Emsian faunules from the Tafilalt in the eastern Anti-Atlas, which are interpreted to reflect at least a regional, if not a global (see Klug et al. 2009), ecological change. These largely limonitized faunules were washed out of early Emsian claystones and marls in various localities. This study from 2008 was, however, restricted to the Tafilalt, and the exact lithostratigraphic position of these faunas within these marls was only poorly known. The older faunule from the Tafilalt contains no ammonoids (compare Becker \& House 2000 and Klug 2001), but acanthodian fin spines, bactritoids, pyrgocystid edrioasteroids, articulated machaeridians, phyllocarid remains, tabulate corals, complete asteropygid trilobites, and a diverse, largely infaunal bivalve assemblage were found there. The younger faunule contains the first ammonoids (already quite abundant), clearly less bactritoids and infauna (generally less benthos), but more epibenthic bivalves and gastropods. The early ammonoids from the upper faunule and the limestone beds have been described by Klug (2001) and Klug et al. (2008). We now measured a new section in the Ouidane Chebbi region in greater detail (compare Belka et al. 1999) to ascertain the exact stratigraphic position of these faunas. In addition to several levels containing limonitized faunas, we discovered ammonoids in the limestones beds above Faunule 2 (Lenzites gesinae, Teicherticeras cf. senior) or in beds or blocks, which could be correlated with it (Anetoceras obliquecostatum, Lenzites gesinae, Weyeroceras angustus).

The Devonian of the eastern Anti-Atlas (Tafilalt and Maïder) has been studied more intensively during the last decades (Massa 1965; Hollard 1974; Alberti 1980, 1981; Becker \& House 1994, 2000; Bultynck \& Walliser 2000a, b; Klug 2001, 2002; Klug et al. 2008, and references therein), while the study of the Dra Valley Devonian is slowly gaining momentum after the pioneering work of Hollard and collaborators (Hollard 1963a-c, 1965, 1967, 1977, 1978, 1981a, b; Hollard \& Jacquemont 1956; Bultynck \& Hollard 1980). Recently, the Lower Devonian lithostratigraphy and biostratigraphy of the Dra Valley area were reviewed by Jansen (2001), Becker et al. (2004d) and Jansen et al. (2007). A correlation between the two regions 
has proved to be difficult because of the more neritic facies of the Dra Valley and the rather pelagic facies of the Tafilalt and partially also the Maïder. Furthermore, the Lower Devonian in the Anti-Atlas contains several clayey intervals, where in situ collection is difficult. In the light of new biostratigraphic results, it has also become possible to interpret facies and sequence stratigraphy (Ouinaimi \& Lazreq 2008, Lubeseder et al. 2009). During a visit to Mdâour-el-Kbîr, an ammonoid locality previously studied by Hollard (1963c), in the eastern Dra Valley (about $350 \mathrm{~km}$ from Ouidane Chebbi), we discovered various ammonoid taxa in situ in the Mdâour-el-Kbîr Formation. Additionally, we found here the two faunules described by Klug et al. (2008) from the Tafilalt for the first time also in the Dra Valley. The lower faunule here consists of bactritoids, bivalves, trilobites, phyllocarids and bioclast-encrusting tabulate corals (Michelinia mdaourensis sp. nov.), which were also found in the eastern Anti-Atlas. These tabulate corals are figured and described here for the first time. Representatives of a second fauna (bactritoids, bivalves, corals, orthoconic nautiloids and trilobites), probably the equivalent of the younger faunule in the Tafilalt, were found higher in the section and are also figured. So far, no ammonoids were reported in this partially limonitised association, but we discovered some slightly higher in the Mdâour-el-Kbîr section. Hollard (1963c, 1978) had already reported Erbenoceras from the lower member of the Mdâour-El-Kbîr Formation, but now Lenzites and Anetoceras could also be extracted from the strata along with Spyroceras as in the Tafilalt.

It is the aim of this study to (1) portray and (2) correlate the detailed sections of the early Emsian sediments of Ouidane Chebbi and Mdâour-el-Kbîr, to (3) describe and (4) illustrate some important faunal elements of the faunas occurring in these two distant regions of the vast Anti-Atlas.

\section{Geological background}

The Anti-Atlas is essentially a NE-SW trending, broad Variscan anticlinorium, which constituted a part of the northwestern margin of the Sahara Craton during the Palaeozoic (Piqué \& Michard 1989). Within its current structure, Lower Devonian outcrops (see Fig. 1A) can be found in the eastern Anti-Atlas (Maïder and Tafilalt; see also Fig. 1D) and in the south-western Anti-Atlas (Dra Valley, Presahara). The Dra or Drâa Valley (Oued Dra) covers a distance of almost $600 \mathrm{~km}$ from Zagora in the NE to Tan-Tan near the Atlantic Ocean in the SW, more or less parallel to the overall strike direction of the Anti-Atlas Palaeozoic. Between the southern flank of the Jebel Bani and northern part of the Jebel Tazout, the main Oued Dra crosses a rather flat area, the Dra Plains, where the basement consists largely of Siluro-Devonian layers (Hollard 1978).
The palaeogeographic position must have been between $40^{\circ}$ and $60^{\circ}$ south, resulting in rather low carbonate production and a cool-water setting during the early Devonian (Lubeseder et al. 2009). At this time, a basinal to carbonate ramp system developed in the eastern Anti-Atlas, while in the south-western Anti-Atlas (Dra Plains) a mixed shallow marine carbonate-siliciclastic system prevailed (Kaufmann 1998, Lubeseder et al. 2009).

In the Dra valley, the Lower Devonian (Pragian-late Emsian) is represented by four successive, sedimentary cycles ("Richs"), which consist of alternations of pelagic (Hercynian) intervals at the bottom and neritic (Rhenish) intervals at the top (Jansen 2001). A "Rich" is typically composed of a lower limestone unit (crinoidal, marly to nodular limestones) overlain by alternating beds of claystones, siltstones and fine sandstones and, at the top, coarse, cross-bedded, massive sandstones with a neritic fauna (Hollard 1981a, Jansen 2001, Becker et al. 2004d, Jansen et al. 2007). A certain lateral variation characterizes these Rich sequences and allows distinguishing between an eastern and a western succession. This is especially true for Rich 1, Rich 3 and Rich 4, which have other formation names in the eastern and western parts. The differences mainly lie in the basal limy facies, while the upper clastic units show a very similar facies and sedimentary structures (Ouinaimi \& Lazreq 2008). The key to correlating the Dra Valley sediments with the eastern Anti-Atlas sediments are the more pelagic, basal limestone units of the Rich cycles, which contain pelagic elements such as ammonoids, dacryoconarids and conodonts similar to the ones reported from the Tafilalt. We focus here on the upper part of Rich 2 (upper part of the Merzâ-Akhsaï Formation) and on the lower part of Rich 3 (lower part of Mdâour-El-Kbîr Formation) in the eastern Dra. The lower part corresponds to the TST of the Rich 3-cycle and the base is usually interpreted as corresponding to the basal Zlíchov Event sensu Chlupáč \& Kukal (1988); see Jansen et al. (2007), Ouinaimi \& Lazreq (2008) and Lubeseder et al. (2009). The overall increasing thickness of sedimentary rocks towards the SW indicates a predominant provenance of siliciclastic supply and the presence of erosive land masses towards the SW and W (Becker et al. 2004d, Lubeseder et al. 2009).

In the Moroccan Anti-Atlas, the Lower Devonian sediments become more pelagic towards the northeast and east. In the Eastern Anti-Atlas, the Lower Devonian is characterised by a rather consistent facies pattern (clays/marls intercalated with limestones), but during the Middle Devonian the previously stable shelf disintegrated and differentiated into a platform and basin topography (Kaufmann 1998). The siliciclastic supply was largely switched off over much of north-west Africa during the Middle Devonian, leading to widespread carbonate deposition in the Anti-Atlas (Lubeseder et al. 2009). Successions 


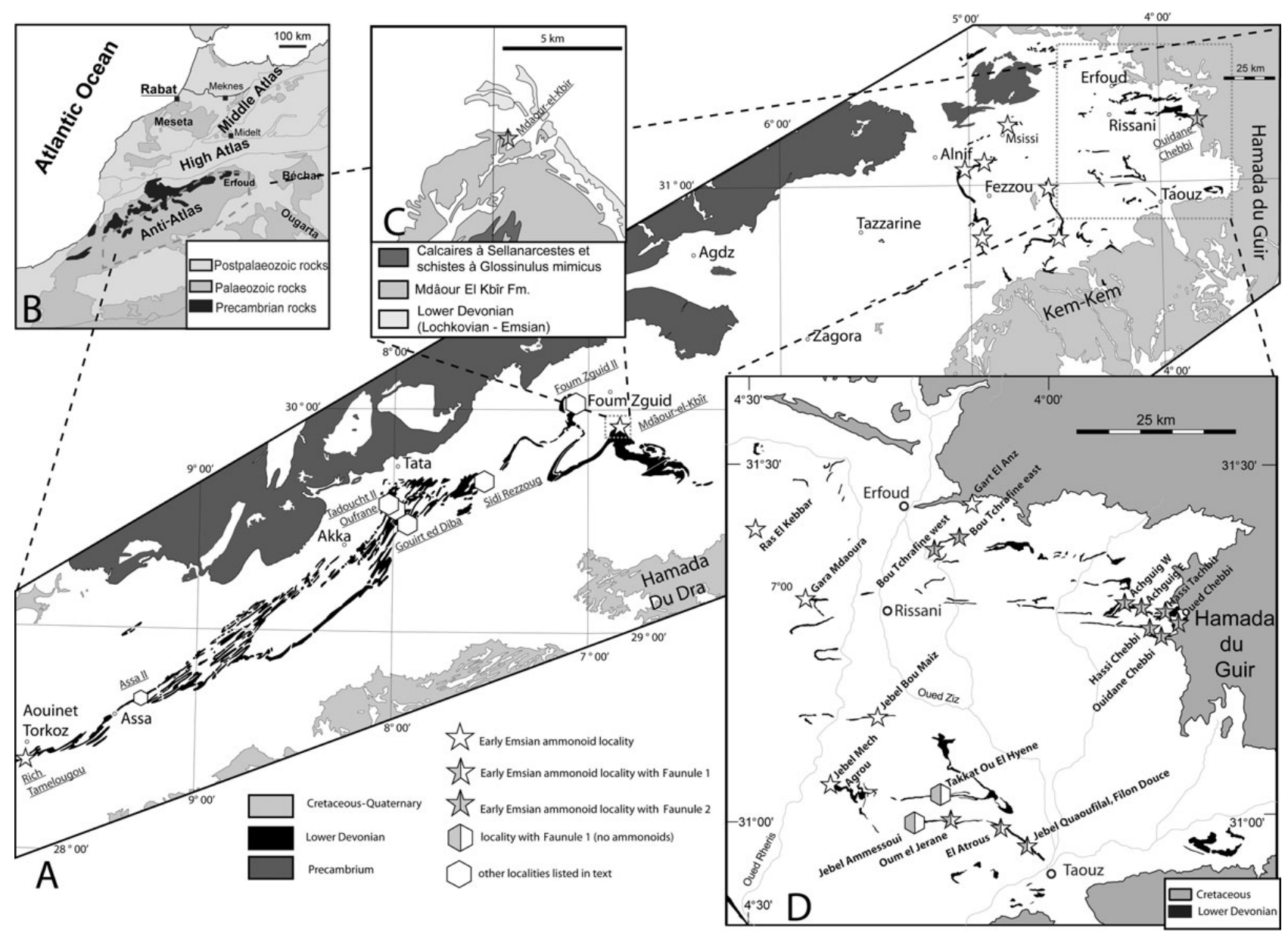

Figure 1. A - simplified geological map of the Moroccan Anti-Atlas showing early Emsian ammonoid localities in the Tafilalt, Maïder and Dra Valley (modified from the Geological Map of Morocco $1: 1,000,000,1985$ ). • B - simplified geological map of Morocco with position of the Anti-Atlas (modified from Klug 2001). • C - simplified geological map of Mdâour-El-Kbîr (modified from Carte Géologique des Plaines du Dra au Sud de l'Anti-Atlas Central, Agadir Tissint - Qued Zemoul $1: 200,000,1971)$ • D - simplified geological map of the Tafilalt (modified from Kaufmann 1998) showing occurrences of Faunule 1 and 2 plus Early Emsian ammonoids.

of the Maïder and Tafilalt are much more condensed compared to the successions of the Dra Valley; they are basically composed of limestone-marl alternations. Some successions of the Maïder show, however, a transitional character (Bultynck \& Walliser 2000b).

\section{Description of sections}

\section{Ouidane Chebbi East}

Lithostratigraphy. - The Ouidane Chebbi section ( $31^{\circ} 14^{\prime} 01^{\prime} \mathrm{N}, 3^{\circ} 49^{\prime} 08^{\prime} \mathrm{W}$; see Figs 1D, 5A) was described in detail rather late compared to other sections of the Tafilalt such as the Achguig, Quaoufilal, Oum El Jerane and Bou Tchrafine sections (Massa 1965; Hollard 1974; Alberti 1980, 1981; Becker \& House 1994). It was previously evaluated by Belka et al. (1999), Klug (2001) and Klug et al. (2008). The sedimentary succession is very si- milar to that of the Bou Tchrafine (Alberti 1980, 1981) and Achguig (Bultynck \& Walliser 2000a, b) sections, but thicker (see Fig. 2). The Early Emsian can essentially be subdivided into two limestone units and two marl/shale intercalations in the Ouidane Chebbi area (Belka et al. 1999, Klug 2001, Klug et al. 2008):

(1) The first unit above the "Pragian Limestone" (Unit B3 of Bultynck \& Walliser 2000a, b) is composed of grey claystones and marlstones.

(2) The subsequent unit consists of massive bluish coloured limestones dubbed the Deiroceras Limestone by Kröger (2008). It corresponds with the "Jovellania" Limestone of Bultynck \& Walliser (2000a, b) and Unit A of Klug (2001).

(3) Above the massive limestone beds, a second unit of claystones and marlstones can be found: Unit $\mathrm{C} 2$ of Bultynck \& Walliser (2000a, b) and Unit B of Klug (2001).

(4) Above the claystones and marls, there is a unit of grey, thin-bedded, nodular limestone. It corresponds to the 
Erbenoceras-Mimagoniatites Beds of Bultynck \& Walliser (2000a, b) and combines Klug's (2001) Units C to E.

The succession is underlain by the "Pragian" Limestone of Bultynck \& Walliser (2000a, b) and overlain by marly clays and clays of "Dalejan" or Late Emsian age (Klug 2001; Bultynck \& Walliser 2000a, b).

The first marl/shale interval is about $18 \mathrm{~m}$ thick at the Ouidane Chebbi East section (see Fig. 2). Its lower part contains a thin unit, rich in brachiopods and trilobites, the so-called "Dalejodiscus Bed" of Klug et al. (2008), which has also been found at other outcrops. Elements of Faunule 1 have been found in situ below this bed in the Ouidane Chebbi section (see Fig. 2A). About $1 \mathrm{~m}$ below this bed, we discovered a pyrgocystid edrioasteroid in situ.

The Deiroceras Limestone is about $3 \mathrm{~m}$ thick and is mainly composed of dacryoconarid wackestone to packstone. It contains orthoconic nautiloids in several layers. This unit becomes more clayey towards the top, where it is rich in trace fossils (Zoophycos and Fucoides).

The second marl/shale interval is about $8.75 \mathrm{~m}$ thick. Elements of Faunule 2 were found in situ in at least two locations. About $2 \mathrm{~m}$ above the base, we found limonitised bivalves and orthocones. About $1 \mathrm{~m}$ below the Erbenoceras Beds, we found limonitised bivalves, brachiopods, gastropods and trilobites. The uppermost part of this mudstone/marl interval occasionally contains favositid colonies (compare Belka et al. 1999), locally in biohermal or biostromal aggregations where they occur in masses.

The claystones are topped by the fossiliferous, nodular and thin-bedded carbonates of the Erbenoceras Beds (see Fig. 3), which form the first larger Devonian ridge of the Ouidane Chebbi area. The limestones are about $11.5 \mathrm{~m}$ thick and are mainly composed of dacryoconarid wackestone. The lower part of the Erbenoceras Beds (Klug's Unit C) is more clayey and the limestone beds are more nodular. In this part, about $1.90 \mathrm{~m}$ above the base, we found Teicherticeras cf. senior in situ. About $1.20 \mathrm{~m}$ above the find of Teicherticeras cf. senior, we found a unit rich in Erbenoceras advolvens and Lenzites gesinae, which also contains Anetoceras obliquecostatum about $100 \mathrm{~m}$ eastward from the section (see Fig. 16A). About $5.5 \mathrm{~m}$ above the base of the Erbenoceras Beds, unit 66 contains at least 2 layers with very large orthoconic nautiloids (probably Metarmenoceras; see Kröger 2008) with septal diameters up to $15 \mathrm{~cm}$ or more (Fig. 4). We found one body chamber, which is filled with phacopid exuvia and green algae, possibly indicating shallower depths, perhaps even within the photic zone. This algae also makes up a large part of a layer within unit 68 , about $35 \mathrm{~cm}$ above the last layer with large orthocones. Above this, there are some intervals which are relatively rich in crinoid debris, in particular two very dark crinoid limestone beds each of about $15 \mathrm{~cm}$ thickness, about $55 \mathrm{~cm}$ and $175 \mathrm{~cm}$ above the base of unit 66 .

The upper limestone layers of the Erbenoceras Beds (dubbed the Mimagoniatites Beds by Bultynck \& Walliser $2000 \mathrm{a}, \mathrm{b}$ ) are bluish and occasionally contain rather poorly preserved Mimagoniatites fecundus in several layers (Units 77, 78 and 79). The unit again becomes more clayey towards the top, where it is overlain by the shales of "Dalejan" age.

Biostratigraphy. - The Ouidane Chebbi section is very similar to the Achguig and Bou Tchrafine sections, which were studied by Alberti (1980, 1981), Becker \& House (2000), Bultynck \& Hollard (1980) and Bultynck \& Walliser $(2000 a, b)$. Alberti $(1980,1981)$ reported dacryoconarids from the Bou Tchrafine section and Bultynck \& Walliser $(2000 \mathrm{a}, \mathrm{b})$ provided conodont data from the Achguig section. Conodont data have been published from the Ouidane Chebbi section by Belka et al. (1999). The fauna described here, along with the beds in which they appear, can be correlated lithologically throughout most of the Tafilalt, especially in the Ouidane Chebbi area (Klug 2001, Kröger 2008, Klug et al. 2008).

The Pragian Limestone contains an association of Nowakia acuaria and Guerichina strangulata, which are typical for the top of the Pragian (in the original sense) in Bohemia (Alberti 1980, 1981; Bultynck \& Walliser 2000b). According to Bultynck \& Walliser (2000b), the Emsian in the GSSP sense falls within the uppermost part of the "Pragian" Limestone, while the Emsian in the traditional sense falls within the lowermost part of the marls/claystones overlying the "Pragian" Limestone at Achguig.

The lower faunule (see Figs 6-8, 10, 15, 17) probably belongs to the "dehiscens" or kitabicus Zone (Belka et al. 1999, Klug et al. 2008). Polygnathus dehiscens might be restricted to Australia, so its usage at other localities needs to be revised (Carls et al. 2008). Alberti (1980) reported Nowakia acuaria s.l. from the middle and upper part of the "Pragian" Limestone and the lower part of the shale/marlstone above it. From the upper part of these mudstones/marls below the Erbenoceras Beds, Alberti (1980) reported Nowakia zlichovensis maghrebiana. The upper faunule (see Figs 8, 17) is probably from the gronbergi-inversus (excavatus-inversus) conodont Zone (Belka et al. 1999, Klug et al. 2008). Alberti (1981) reported Nowakia zlichovensis maghrebiana from the lower

Figure 2. A - lithological column of the Mdâour-El-Kbîr section, Dra Valley, western Anti-Atlas (Morocco) with stratigraphical occurrences of Faunules 1 and 2 plus ammonoids. • B - lithological column of Ouidane Chebbi East, northeastern Anti-Atlas (Morocco), with stratigraphical occurrences of Faunules 1 and 2 plus ammonoids. $\bullet \mathrm{C}$ - stratigraphical correlation between the two sections. 


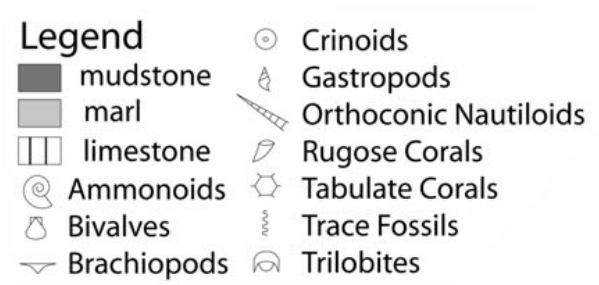

$\square \mathrm{A}$
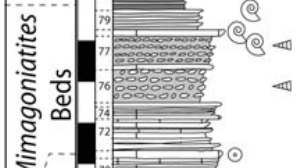

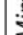

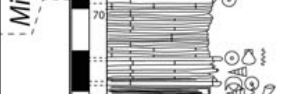$$
\stackrel{2}{2}
$$

㲾

¿ัญ

离
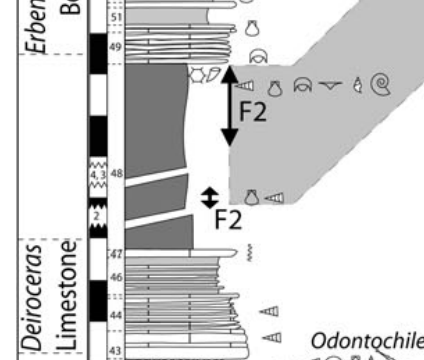

Oั.
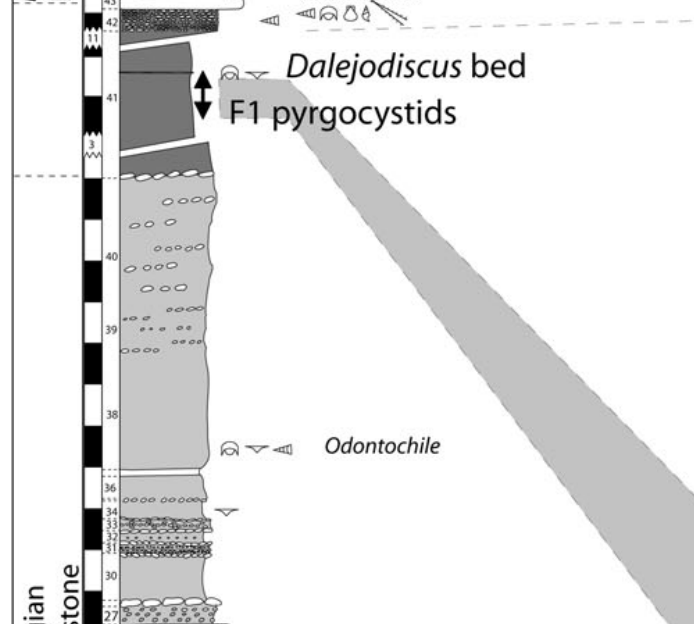

흃
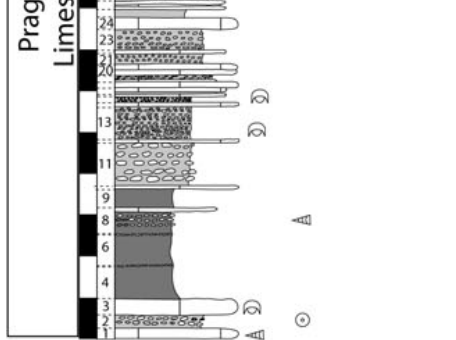

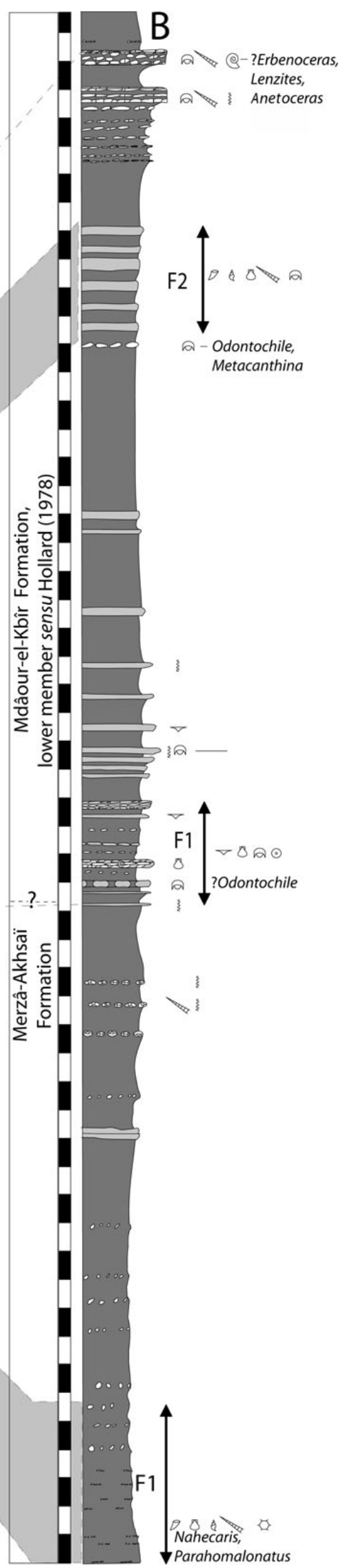




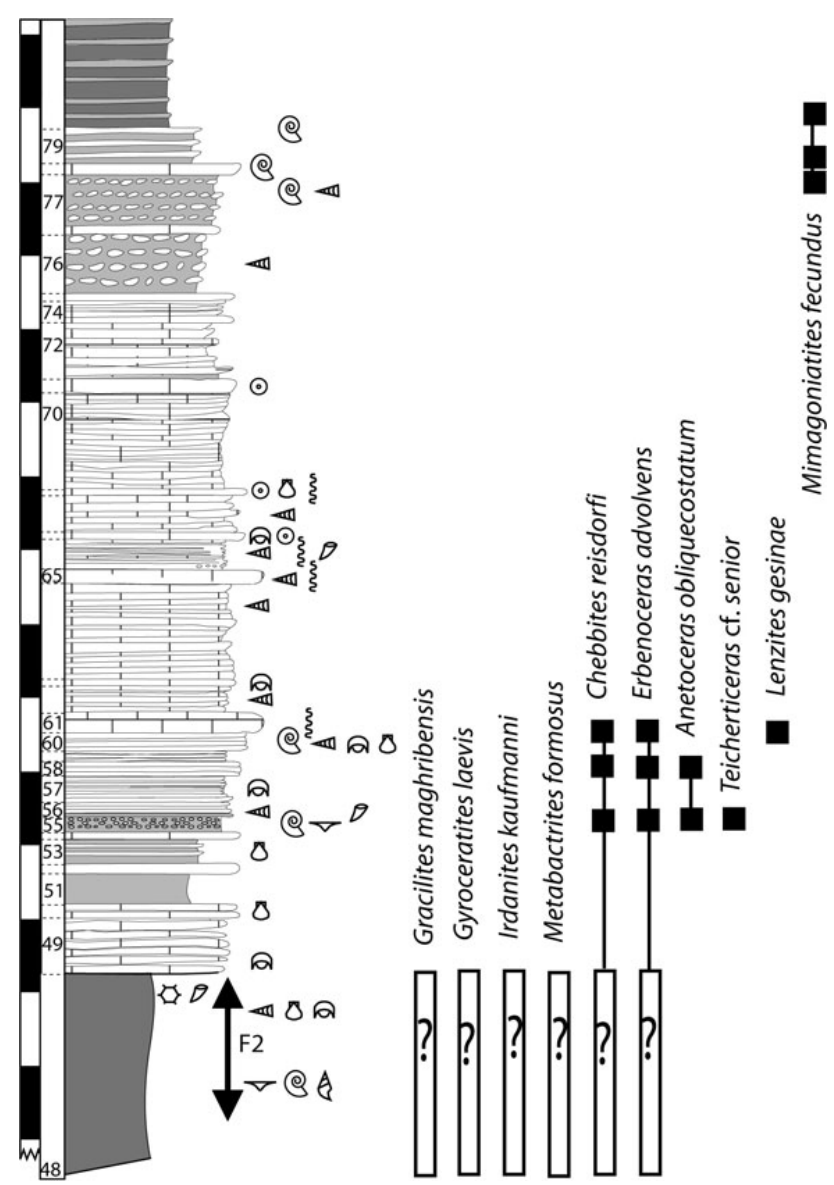

Figure 3. Enlarged lithological column of the Erbenoceras Beds of Ouidane Chebbi East, northeastern Anti-Atlas (Morocco) with distribution of ammonoids.

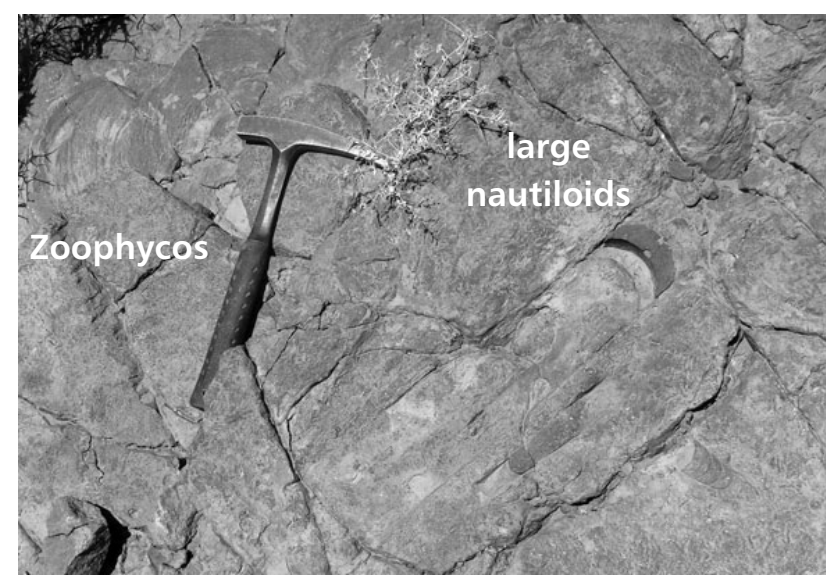

Figure 4. Picture of a bedding plane from unit 66 (Unit D of Klug 2001, Erbenoceras Beds) with large orthonic nautiloids and the trace fossil Zoophycos on the bedding plane below. See the geological hammer (about $30 \mathrm{~cm}$ ) for scale.

part of these marls at Bou Tchrafine and Nowakia cf. praecursor from the limestone unit just above these beds (Unit C of Klug 2001). Klug et al. (2008) explicitly reported Nowakia zlichovensis as part of Faunule 2 at Ouidane Chebbi. The second limonitised fauna contains some of the earliest Moroccan ammonoids, although probably not the very earliest, as Klug (2001) reported poorly preserved ammonoids from the limestones below Faunule 2 (Klug 2001) at Ras El Kebbar (about $46 \mathrm{~km}$ of Ouidane Chebbi). No limonitised ammonoids were collected in situ while measuring the section at Ouidane Chebbi, but they were found previously within the claystones/marls of Unit B (sensu Klug 2001). However, these probably derived from the upper rather than the lower part of the marls at Ouidane Chebbi (compare Belka et al. 1999, Klug 2001, Klug et al. 2008). So far, Chebbites, Erbenoceras, Gracilites, Gyroceratites, Irdanites and Metabactrites have been extracted from these marls at Ouidane Chebbi (Belka et al. 1999, Klug 2001, Klug et al. 2008).

Ammonoids have also been reported from the limestone beds (Erbenoceras Beds) above Faunule 2. Alberti (1981) reported Nowakia cf. praecursor, Nowakia barrandei and Nowakia elegans from this second limestone unit at Bou Tchrafine.

The following genera have been previously reported from the nodular limestone unit (Unit C of Klug's 2001 Erbenoceras Beds) just above Faunule 2 at Ouidane Chebbi: Anetoceras, Chebbites, Erbenoceras, Gracilites, Gyroceratites, Irdanites, Metabactrites by Belka et al. (1999) and Klug (2001). We can now report the additional presence of Teicherticeras cf. senior (see Fig. 17) found in situ in these beds, which fall in the range of Anetoceras obliquecostatum. Teicherticeras senior Chlupáč \& Turek was reported from the praecursor Zone in the upper part of the Zlíchov Limestone near Pekárkův mlýn in Bohemia, where it was also associated with a different species of Anetoceras (Anetoceras oriens). It is the earliest known ammonoid fauna so far from the Prague Basin (Chlupáč \& Turek 1983).

Above it, a unit rich in Erbenoceras appears, associated with Anetoceras and Lenzites in its upper part (Unit D of Klug 2001). A rare Weyeroceras find (Fig. 18A) associated with Erbenoceras could be correlated with this interval. In the upper part of Unit E, we found badly preserved Mimagoniatites fecundus - mostly body chambers in several beds, in at least three layers, which probably already fall in the elegans Zone (see Klug 2001).

\section{Mdâour-El-Kbîr}

Lithostratigraphy. - Mdâour-El-Kbîr （N2953'50", W6 ${ }^{\circ} 50^{\prime} 55^{\prime \prime}$; see Figs $1 \mathrm{C}$ and 5B-D) is the type locality of the Mdâour-El-Kbîr Formation of the Rich Group (Hollard 1981a). Hollard (1978) was the first author who roughly described the Mdâour-el-Kbîr section, but no detailed description has been published since. Mdâour-el-Kbîr is located about $20 \mathrm{~km}$ south-southeast from Foum Zguid. The 

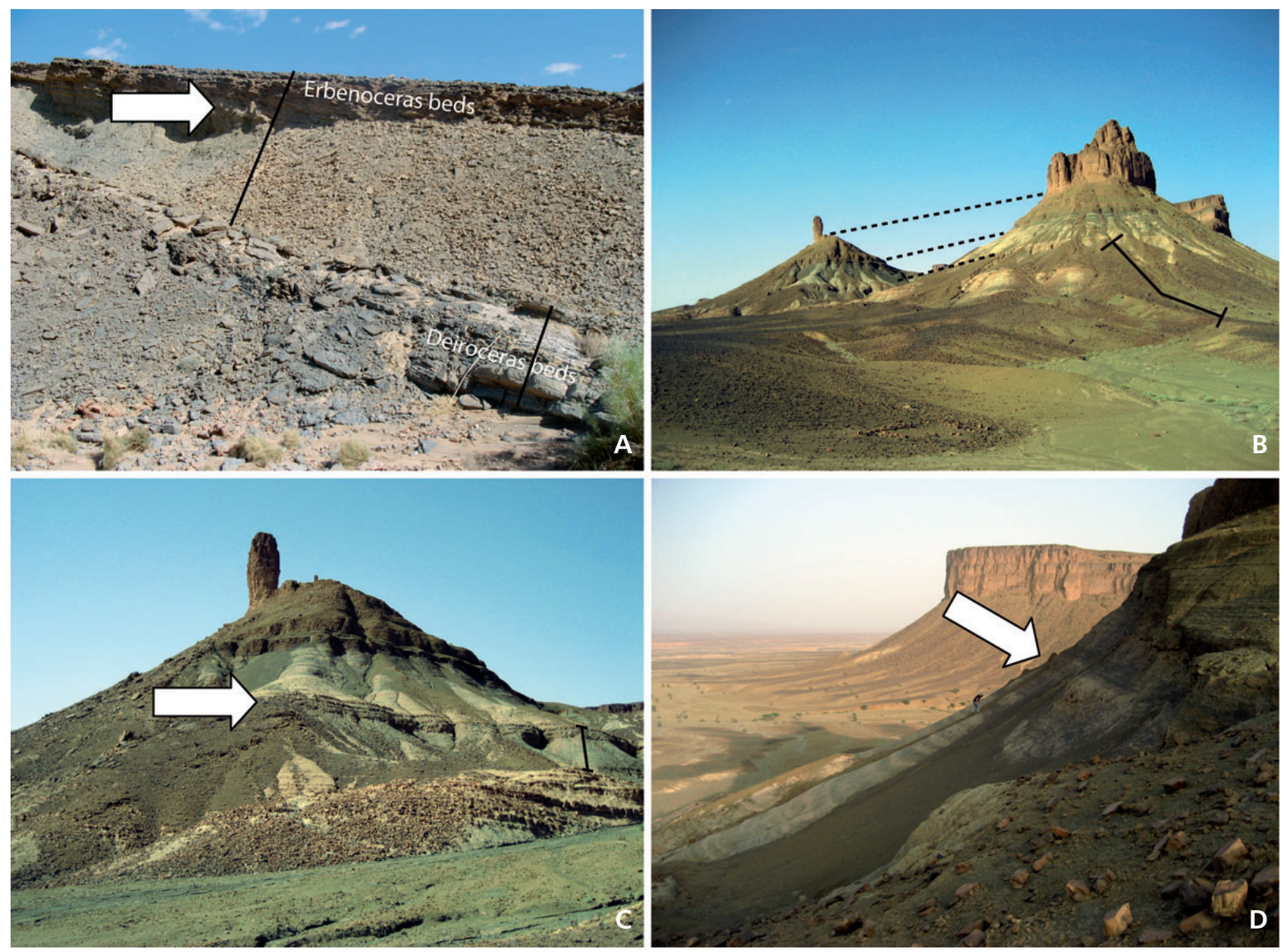

Figure 5. A-eastward view of the Ouidane Chebbi section. Approximately $20 \mathrm{~m}$ of Devonian section is visible and the arrow indicates the place where we found the Teicherticeras cf. senior specimen. • B - outcrop at Mdâour-el-Kbîr with position of the lower part of the section at the eastern outcrop, where most of Faunule 1 and Faunule 2 were collected. $\bullet \mathrm{C}$ - enlarged detail of the upper part of the section at the western outcrop with position of the ammonoid bearing bed (arrow), where we found more elements of Faunule 2 and ammonoids. $\bullet$ D - detail of the upper part of the profile at the western outcrop with KDB collecting Faunule 2, an arrow marks the bed with ammonoids.

Mdâour-El-Kbîr Formation was studied recently, about 25 km SW of Foum Zguid (Jansen 2001; Jansen et al. 2004, 2007), but there, the lower part of the Mdâour-el-Kbîr Formation with the basal limestone is not exposed (Jansen et al. 2004). It is underlain by the Merzâ-Akhsaï Formation, which is also present in the SW Dra Valley. The top of the Merzâ-Akhsaï Formation or base of the Mdâour-el-Kbîr Formation is usually interpreted to correspond with a break in sedimentation and a basal erosional surface or a very condensed interval (Hollard 1978, Jansen et al. 2007, Ouanaimi \& Lazreq 2008). The Mdâour-El-Kbîr Formation reaches a total thickness of almost $300 \mathrm{~m}$ at its type locality according to Hollard (1978). It corresponds largely with the Rich d'El Annsar or Rich 3 sensu Hollard (1963a, 1965, 1967). Hollard (1978) divided it in 3 parts ("members").

The lower, more pelagic unit ("Calcaires gris noduleux et marnes grises"; "Membre inférieur" sensu Hollard 1978) is mainly clayey and has several fossil rich calcareous intercalations in the middle, which contain bactritoids, bivalves, brachiopods, corals, dacryoconarids, orthoconic nautiloids, goniatites, phyllocarids and trilobites (see Figs 6-8, 15-17).

The middle unit ("Pélites grises; Membre moyen" sensu Hollard 1978) and the upper unit ("Grès d'El Mdâour El Srhir" and "Grès et lumachelles du Mdâour-El-Kbîr"; "Membre supérieur" sensu Hollard 1978) are more neritic, and consist, respectively, of siltstones and sandstones, and of sandstones and coquinas. We will focus here on the upper part of Merzâ-Akhsaï Formation and the lower member of the Mdâour-El-Kbîr Formation, that contain the limonitised and ammonoid faunas, which are similar to those reported from the Tafilalt.

According to Hollard (1978), the lower half of the lower member of the Mdâour-El-Kbîr Formation contains three more calcareous levels. The first more calcareous level forms the base of the Mdâour-El-Kbîr Formation and 


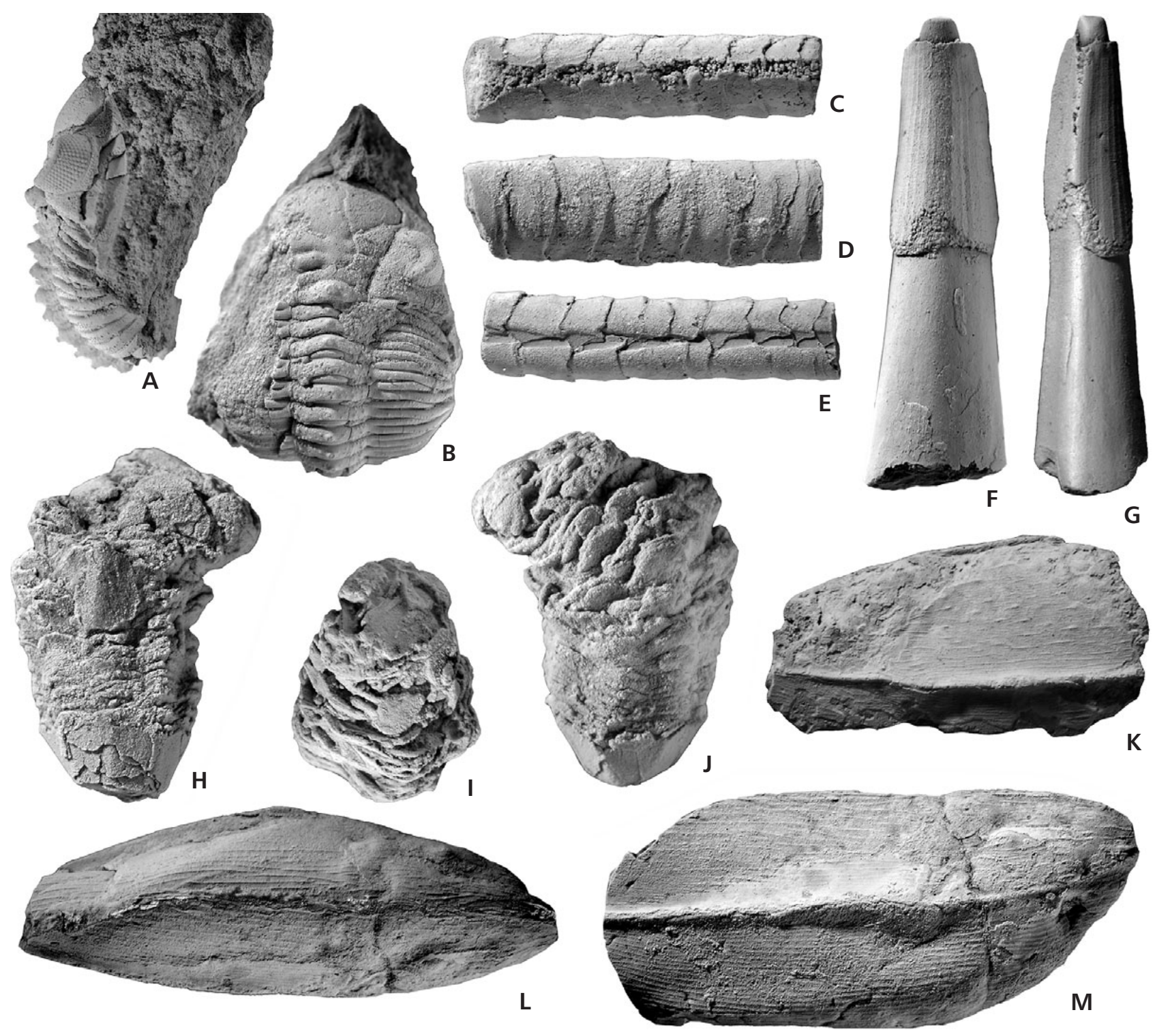

Figure 6. Early Emsian trilobites, annelids, hyolithids, edrioasteroids and phyllocarids from Mdâour-El-Kbîr (Dra region) and from various localities in the Tafilalt. - A, B - Pilletina zguidensis Morzadec, 2001; lateral and dorsal views of cephalon with part of the thorax; $\times 2$; PIMUZ 28387. - C-E - Lepidocoleus rugatus Klug et al., 2008; ventral, lateral and dorsal views, internal mould, $\times$ 4; PIMUZ 28388. • F, G - Orthotheca sp; dorsal and lateral views, internal mould with part of the shell preserved with longitudinal ornamentation, $\times 4$; PIMUZ 28389. $\bullet \mathrm{H}, \mathrm{I}, \mathrm{J}-$ Rhenopyrgus flos Klug et al., 2008; lateral, oblique ventral and lateral views, internal mould, $\times$ 4; PIMUZ 28390. $\bullet \mathrm{K}-$ Nahecaris malvinae? Klug et al., 2008; lateral view, internal mould of right valve; PIMUZ 28391; $\times 4$. $\bullet$ L, M - Nahecaris malvinae Klug et al., 2008; dorsal view and lateral views of the carapace; refiguration of PIMUZ 27059 modified from Klug et al. 2009; × 4. • A, B - Mdâour-El-Kbîr; Mdâour-El-Kbîr Formation (Faunule 2). • C-E, H-J - Jebel Ammesoui; Seheb El Rhassel Group, Unit B3 of Bultynck \& Walliser 2000a, b (Faunule 1) • F, G, K - Takkat Ou El Heyene; Seheb El Rhassel Group, Unit B3 of Bultynck \& Walliser 2000a, b (Faunule 1). • L, M - Mdâour-El-Kbîr; Merzâ-Akhsaï Formation (Faunule 1). All specimens whitened with ammonium chloride.

Figure 7. Early Emsian trilobites from the Dra Valley and the Tafilalt. • A, B, D, E, H - Parahomalonotus planus planus (Koch, 1883). A, D - lateral view of cephalon and dorsal view of the thorax, $\times 2$; PIMUZ 28379. B -dorsal view of cephalon, $\times 2$; PIMUZ 28380. E, $\mathrm{H}-$ dorsal views, thorax and cephalon respectively, $\times$ 1.6; PIMUZ 28381. • C -Pilletina sp., ventral view, duplicature and hypostome, $\times$ 4; PIMUZ 28382. • F, G, I, J - Metacanthina wallacei (Termier \& Termier, 1950b). F - part of cephalon with genal spine and part of the thorax, $\times 4$; PIMUZ 28383. G, J - lateral and dorsal views, cephalon and part of the thorax respectively, $\times 4$; PIMUZ 28386. I - dorsal view of the pygidium, $\times 4$; PIMUZ 28385. $\bullet \mathrm{K}-$ Pilletina zguidensis Morzadec, 2001, dorsal view of pygidium, exoskeleton preservation, × 5; PIMUZ 28384 • A, D, G, I, J - Mdâour-El-Kbîr; Merzâ-Akhsaï Formation (Faunule 1). - B, E, H - Oufrane; Merzâ-Akhsaï Formation (?lower Emsian). C, F - El Atrous; Seheb El Rhassel Group, Unit B3 of Bultynck \& Walliser 2000a, b (Faunule 1). K - Mdâour-El-Kbîr; Mdâour-El-Kbîr Formation (Faunule 2). All specimens whitened with ammonium chloride. 
Kenneth De Baets et al. • Zlíchovian faunas with early ammonoids, Anti-Atlas
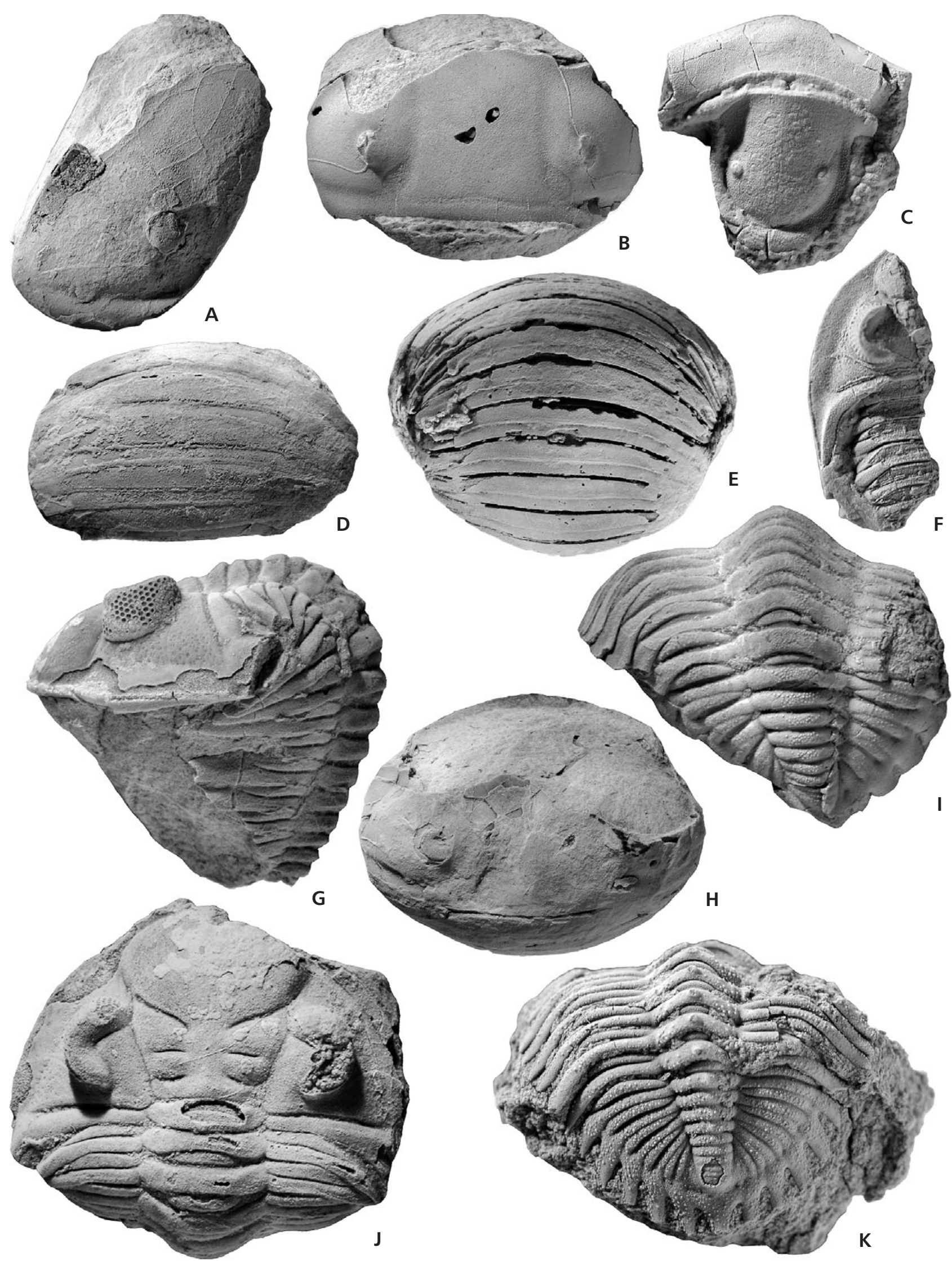
the middle more calcareous level is the one containing Erbenoceras advolvens according to Hollard (1963c, 1978).

Our section (see Fig. 2B) starts with $4.4 \mathrm{~m}$ of silty claystones intercalated with nodules containing the first faunule (see Figs 6-8, 10, 15, 16). They are underlain by at least $6 \mathrm{~m}$ of greenish, silty shales. The lithology seems to change very little for about $11 \mathrm{~m}$ with the exception of a more marly layer $7.85 \mathrm{~m}$ above the silty shales with Faunule 1. Three layers of rather large septaria, often rich in trace fossils, intercalated by silty shales, follow above. This part of the section clearly has a higher carbonate content, starting about $24 \mathrm{~m}$ above the base of the section, where several layers are rich in bivalves, trilobites and trace fossils (Zoophycos, Planolites). We interpret this to be the base of the Mdâour-El-Kbîr Formation and to correspond to the lower more calcareous unit of Hollard (1978). The boundary between the Mdâour-El-Kbîr Formation and Merzâ-Akhsaï Formation supposedly coincides with an abrupt change from neritic sandstones to (hemi)pelagic limestones (Fig. 2). Hollard (1978) assumed that this facies change corresponds to a break in sedimentation or a very condensed interval. However, no clear indications of a sedimentary break or hiatus were seen, but this could have been obscured by the poor outcrop quality at this level. In fact, it has been reported from other outcrops (Hollard 1978, Quanaimi \& Lazreq 2008).

The section becomes more limy again at $39.85 \mathrm{~m}$, starting with dark limestone nodules rich in trilobites (?Odontochile, Metacanthina). The nodule layers are overlain by six silty claystone/ marlstone alternations with a total thickness of $4.4 \mathrm{~m}$, containing Faunule 2 (see Figs 6-8, $15,17)$. It is overlain by silty claystones, which become more limy towards the top, where they are intercalated by limestone nodules. Above it, two intervals with nodular limestones intercalated by marly limestones occur, which are each about $55 \mathrm{~m}$ thick. The lower one starts at $49 \mathrm{~m}$ and contains trilobites (Metacanthina, ?Odontochile) and trace fossils. The upper one starts at $50.35 \mathrm{~m}$ and contains orthoconic nautiloids (Orthocycloceras, Spyroceras; see
Fig. 17) and ammonoids (Anetoceras, ?Erbenoceras, Lenzites; see Fig. 16). It is overlain by $16 \mathrm{~m}$ of silty claystones, which become more marly towards the top (the third more limy interval of Hollard 1978) and the first sandstones appear about $28.5 \mathrm{~m}$ above the level containing ammonoids, which probably correspond to the start of Hollard's (1978) second member.

Biostratigraphy. - The lower faunule at Mdâour-El-Kbîr in the earliest Emsian is very similar to that reported from the Tafilalt ("Faunule 1" of Klug et al. 2008) and contains: bactritoids (Devonobactrites*), bivalves (Cuculella*, Palaeoneilo*, Phestia rostellata, Nuculoidea, ?Nuculopsis), brachiopods (cf. Protathyris*), rugose and tabulate corals (Michelinia sp. nov.*), gastropods (Eotomarioidea gen. et sp. indet.*, Loxonematoidea gen et sp. indet.*), phyllocarids (Nahecaris malvinae*) and trilobites (Metacanthina wallacei*, Parahomalonotus planus planus) [The taxa listed above with an asterisk, and below, also appear in Faunule 1 in the Tafilalt].

The holotype of Nahecaris malvinae from Klug et al. (2008; refigured here in Fig. 6L, M) also derives from Faunule 1 at Mdâour-El-Kbîr. At Mdâour-El-Kbîr, bivalves are typically preserved with ornamentation visible on the shells (see Fig. 15A, B, E-M, R, Z), as opposed to those in Faunule 1 of the Tafilalt, where they are preserved as internal moulds only. Parahomalonotus planus planus has so far only been reported from the Pragian of the Merzâ-Akhsaï Formation near Assa and Tadoucht (Schraut 2000, Jansen et al. 2004) but has now been identified in the Merzâ-Akhsaï Formation (?lower Emsian) at Oufrane and Mdâour-El-Kbîr (lower Emsian; Fig. 7A, B, D, E, H). The taxon ranges into the Emsian in localities in Germany (Schraut 2000). According to Jansen et al. (2007), the upper part of the Merzâ-Akhsaï Formation correlates well with the Pragian Limestone at Achguig and Ouidane Chebbi, but the finds of Faunule 1 might indicate it also partially correlates with the marls/mudstone interval above the "Pragian" Limestone. Becker et al. 2004a reported conodonts from the excavatus zone from their unit 21 ,

Figure 8. Molluscs and brachiopods from the early Emsian of Mdâour-El-Kbîr (Dra region) and various localities in the Tafilalt. - A, B, F - Plagiostomoceras hassichebbiense Klug et al., 2008; lateral, ventral and septal views, × 3; PIMUZ 28392. • C, H - Plagiostomoceras sp.; septal and lateral views, $\times 3$; PIMUZ 28393. $\bullet$ D, I - Murchisoniceras murchisoni (Barrande, 1865); lateral and septal views, $\times 3$; PIMUZ 28394. • E, J - Devonobactrites obliqueseptatus (Sandberger \& Sandberger, 1852); lateral and ventral views, × 3; PIMUZ 28395. • G, K, L, N, O - Planitrochus sp. G, K, L - dorsal, lateral and apical views, $\times 3$; PIMUZ 28396. N, O - apical and lateral views, $\times 3$; PIMUZ 28398. • M - Loxonematoidea gen. et sp. indet.; lateral view, $\times 3$; PIMUZ 28397. • P, Q - Hyolithes sp.; regurgitate, coprolite or trace fossil with aligned hyolithids?, $\times 3$; PIMUZ 28399 . $\bullet$ R, S, T, Y, W, X, AC, AD - Lukesispira aff. pulchra Frýda \& Manda, 1997. R, S - apical and lateral views, × 3; PIMUZ 28400. W, X - apical and lateral views, $\times$ 4; PIMUZ 28404. AC, AD - lateral and dorsal views, $\times 3$; PIMUZ 28453. T, Y - apical and lateral views, $\times 3$; PIMUZ 28401. • U, Z - cf. Protathyris sp.; ventral and posterior view, $\times 2$; PIMUZ 28402. $\bullet \mathrm{V}-$ Lunulacardiidae gen. et sp. indet. with "Panenka" sp. (small specimen), $\times 2$; PIMUZ 28403. • AA, AB, AE - Gastropoda gen. et sp. indet.; ×3. • AA, AB - lateral and dorsal views; $\times 3$; PIMUZ 28405 • AE - lateral view, $\times 3$; PIMUZ 28406 . - A, B, F, V, AE - Hassi Tachbit; Seheb El Rhassel Group, Unit B of Klug 2001 (Faunule 2). • C-E, H-J, N, O, T, W, X, Y, AC, AD - Mdâour-El-Kbîr; Mdâour-El-Kbîr Formation (Faunule 2). • G, K, L - Achguig East; Seheb El Rhassel Group, Unit B of Klug 2001 (Faunule 2). • M, R, S, U, Z, AA, AB - Mdâour-El-Kbîr; Merzâ-Akhsaï Formation (Faunule 1). P, Q - El Atrous; Seheb El Rhassel Group (Faunule 1). 
Kenneth De Baets et al. • Zlíchovian faunas with early ammonoids, Anti-Atlas

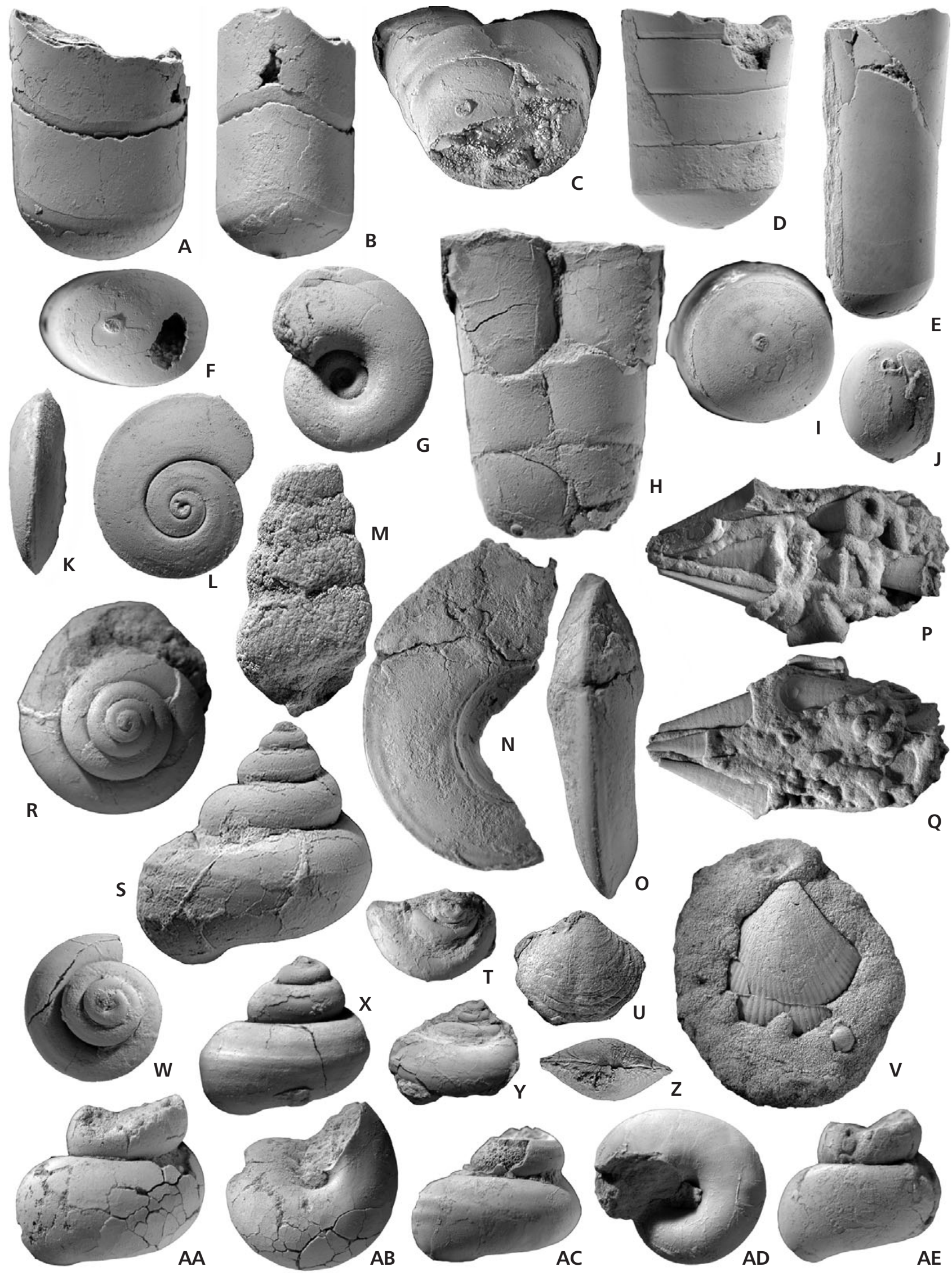


which might partially derive from the upper part of the Merzâ-Akhsaï Formation, but probably derive from the more limy Unit 21b of Jansen (2001), which already falls within the Oui-n'-Mesdoûr Formation. The latter formation is the equivalent of the Mdâour-El-Kbîr Formation in the western Dra Valley.

Several biostratigraphically relevant groups have been reported from the lower member of the Mdâour-El-Kbîr Formation: ammonoids (Hollard 1963c, 1978; Bultynck \& Hollard 1980), conodonts (Becker et al. 2004a, Jansen et al. 2007), and tentaculitids (Lardeux 1969, Hollard 1978, Bultynck \& Hollard 1980). It is hard to evaluate these findings because usually neither lithological sections nor the exact position in the lower member of the Mdâour-El-Kbîr Formation are reported. Furthermore, most of these fossils do not derive from the type locality. Nevertheless, most of these fossil occurrences appear to be consistent with our findings.

According to Jansen et al. (2007), the lower part of the Mdâour-el-Kbîr Formation correlates well to the Deiroceras Limestone. This is consistent with finds of the dacryoconarid Nowakia cf. zlichovensis (Hollard 1978) and conodonts from the excavatus Zone from the lower part of the Mdâour-el-Kbîr Formation at Sidi Rezzoug, about $50 \mathrm{~km}$ from the type locality (Jansen et al. 2007). Faunule 2 was found about $20 \mathrm{~m}$ above the base of the Mdâour-el-Kbîr Formation. The find of Faunule 2 might indicate that this part of the section correlates, in part, to the marls above the Deiroceras Limestone at Ouidane Chebbi and other localities in the Tafilalt.

The upper Faunule ("Faunule 2" of Klug et al. 2008) at Mdâour-el-Kbîr contains: bactritoids (Devonobactrites obliqueseptatus*), bivalves (Lunulacardiidae gen. et $\mathrm{sp}$. indet.*), tabulate and solitary rugose corals, gastropods (Loxonematoidea gen et sp. indet., Planitrochus*), orthoconic nautiloids (Murchisoniceras*, Plagiostomoceras*) and trilobites (Pilletina zguidensis) [The taxa listed with an asterisk are also found in the Faunule 2 of the Tafilalt].

Several taxa also have been found in Faunule 2 of the Tafilalt. Especially, Planitrochus (Fig. 8N, O) is a common element of Faunule 2 in the Tafilalt. However, unlike the Tafilalt, no ammonoid remains have been found in Faunule 2, nor have any edrioasteroids been found in Faunule 1 at Mdâour-el-Kbîr. Additional sampling from the Dra Valley would certainly increase the number of taxa from these faunules.

According to Hollard (1963c, 1978), his ammonoid finds are derived from the middle limy part of the lower member of the Mdâour-el-Kbîr Formation. Bultynck \& Hollard (1980) reported the conodonts Ozarkodina steinhornensis miae and Latericriodus bilatericrescens bilatericrescens associated with an Erbenoceras find from the Mdâour-el-Kbîr Formation. They also reported the same conodont taxa (in addition also Polygnathus gronbergi and
Latericriodus aff. deckmanni) in a sample (BTW2) from the Erbenoceras Beds at Bou Tchrafine. Belka et al. (1999) did not find Ozarkina steinhornensis miae in the Erbenoceras Beds at Ouidane Chebbi, but in the lower Deiroceras Limestone. Bultynck (2008, written communication) suggested that this Erbenoceras specimen and conodonts in his log were collected from the lower part of the Mdâour-el-Kbîr Formation rather than the middle part. The previous reports of Erbenoceras advolvens (Hollard 1963c, 1978; Bultynck \& Hollard 1980) and new finds of Anetoceras and Lenzites (Fig. 16B, D, E, H) within the lower member of the Mdâour-El-Kbîr Formation (middle more limy level) indicate a late Zlíchovian age. The new ammonoids we found in the middle part of the Mdâour-el-Kbîr Formation suggest a correlation with the middle part of the Erbenoceras Beds (Unit D of Klug 2001), because Lenzites and Erbenoceras have so far only been reported together from the middle part of the Erbenoceras Beds and the first Lenzites were also reported from the Erbenoceras Beds (Unit D). The middle part of the lower member probably correlates instead with the base of the Erbenoceras Beds. This interpretation is consistent with findings of the dacryoconarid Nowakia cf. praecursor (Hollard 1978) and new ammonoid finds (Anetoceras cf. obliquecostatum, Lenzites gesinae) described in this paper, in addition to Erbenoceras advolvens (Hollard 1963c, 1978). Our ammonoid finds at Mdâour-el-Kbîr were associated with Spyroceras fukujiense (Fig. 17J, K), as in Ouidane Chebbi East (Fig. 17B), and other places in the Tafilalt (e.g., Jebel Mech Irdane, Fig. 17A).

\section{Faunal associations, early Emsian ammonoid succession and its correlation}

Faunule 1 has subsequently been found in several localities of the Tafilalt (see Fig. 1D for an overview), including the Ammessoui syncline at localities (Takkat Ou El Hyene and Jebel Ammessoui; see Fig. 7) closer to the Maïder than the Ouidane Chebbi area. Some additional finds are shown on Figs 6-8, 10-15 and 17. Some of the more important new finds merit discussion.

Two Palaeozygopleura specimens of Faunule 1 had been overgrown by Michelinia mdaourensis sp. nov. (Fig. 10C, H) and specimens preserved as external moulds show forms with ornamentation. They could be assigned to Palaozygopleura vaneki, which has so far only been reported from the Chýnice Limestone of the Barrandian (elegans Zone, early Emsian; see Frýda et al. 2008). We also discovered strange limonitised clusters of the hyolitid Hyolithes sp. (Fig. 8P, Q). In some cases, their apertures are orientated towards each other, but in other specimens the shells were orientated in a subparallel fashion. It is unclear if this arrangement is in vivo or post-mortem. In the 
latter case, the hyolithids might be part of a regurgitate, a coprolite or some other kind of trace fossil filled with hyolithids. In the Amessoui syncline and in the Maïder, the limonitised Faunule 2 has not been found so far.

A similar fauna which also contains Michelinia mdaourensis sp. nov. is described and figured here from the Merzâ-Akhsaï Formation at Mdâour-el-Kbîr in the western Anti-Atlas (Fig. 10N-Q). Additionally, Petridictyum sp., previously described from the Merzâ-Akhsaï Formation at locality AS167 of Hollard (1981a) by Plusquellec (2007), has now been discovered in Faunule 1 at Hassi Tachbit and Oum El Jerane in the Tafilalt (Fig. 15S, $\mathrm{V}-\mathrm{X})$. There are other similarities between Faunule 1 of Mdâour-el-Kbîr and the faunule between the "Pragian Limestone" and the "Deiroceras Limestone" at Ouidane Chebbi as well as other localities in the Tafilalt, which might indicate that both faunules are correlated. There are however also differences. So far no edrioasteroids have been found within Faunule 1 at Mdâour-el-Kbîr and Parahomalonotus has so far not been reported from this stratigraphic level from the Tafilalt.

In the Tafilalt, Faunule 2 contains some of the first ammonoids, but so far, ammonoids have not been found in this interval in the Mdâour-el-Kbîr Formation. Early Emsian ammonoids have previously been reported from several localities in the Tafilalt and Maïder (Termier \& Termier 1950a; Petter 1959; Hollard 1963c; Becker \& House 1994, 2000; Belka et al. 1999; Klug 2001; Klug et al. 2008). From the Dra Valley, finds of early ammonoids are still restricted to the Mdâour-El-Kbîr Formation at Mdâour-el-Kbîr in the eastern Dra Valley (Hollard 1963c, 1978) and recently, Becker et al. (2008) reported similar ammonoids (Erbenoceras sp.) from the Oui-n'-Mesdoûr Formation at Rich Tamelougou in the western Dra Valley. The earliest, well-dated fauna containing the genera Anetoceras and Ivoites worldwide comes from Guangxi in southern China (Ruan \& Mu 1989, Yu \& Ruan 1988, Ruan 1996). It is associated with Nowakia praecursor and is probably also the only real Nowakia zlichovensis from China (Ruan \& Mu 1989, Becker \& House 1994). The earliest Moroccan faunas are probably only slightly younger than the oldest, well-dated early ammonoid finds of China, as they probably derive from beds with or just above Nowakia zlichovensis (Alberti 1980, 1981; Becker \& House 1994; Klug 2001; Klug et al. 2008).

In Morocco, the exact assemblages or ranges of these taxa are not yet known, but more loosely collected specimens (residuum of eroded claystones and marls) from shales between the Deiroceras and Erbenoceras Beds are already associated with more closely coiled forms, as is the case in several localities of early Emsian ammonoids, including most Chinese localities (Ruan 1981, 1996). Gyroceratites laevis was long thought to appear after (Becker \& House 1994) or together with Mimagoniatites fecundus
(Chlupáč \& Turek 1983). By contrast, this index ammonoid ranges within the upper part of the marls containing Faunule 2, below occurrences of Nowakia cf. praecursor and are present here below the Moroccan occurrence of Mimagoniatites fecundus (Klug 2001). Bou Tchrafine is also the type locality of "Kokenia filalensis" (= Erbenoceras advolvens) with the type horizon probably lying in the praecursor Zone (Alberti 1981, Becker \& House 1994).

Faunule 2 occurs below local occurrences of Anetoceras obliquecostatus and Teicherticeras cf. senior within Klug's (2001) Unit C, an assemblage similar to the oldest reported ammonoids from the Prague Basin. The ammonoids of Unit $\mathrm{C}$ are also very similar to the ammonoids reported from the praecursor Zone of Guangxi in China (including Anetoceras, Chebbites, Erbenoceras, Irdanites and Teicherticeras). The auguritid Weyeroceras angustus was previously reported from a level above the occurrence of Erbenoceras (?elegans Zone; see Klug 2001), but it was now also found for the first time in the beds of unit D associated with Erbenoceras advolvens (?barrandei Zone; see Klug 2001). Its presence is in accordance with other occurrences of primitive Auguritinae (Gaurites, Weyeroceras) in the barrandei and elegans zones of Spain (Montesinos \& García-Alcalde 1996) and Uzbekistan (Bogoslovsky 1984). Some elements such as Mimosphinctes and Palaeogoniatites, commonly found in the barrandei or elegans Zone of Spain and Bohemia, have not yet been found in Morocco (Chlupáč \& Turek 1983, Montesinos \& Truyols-Massoni 1987, Montesinos 1991, Carls 1999). Mimosphinctes has been reported by some authors to co-occur with "Anetoceras" (Bultynck \& Hollard 1980) in Morocco, but no specimens were figured and, if such specimens are not illustrated we can assume that they might be Chebbites, a closely related mimosphinctid with coarse ribbing, quite common in Faunule 2 and in the lower part of the Erbenoceras Beds (Klug 2001).

The first Mimagoniatites fecundus are found above the beds containing Erbenoceras advolvens and Weyeroceras angustus at Ouidane Chebbi (Belka et al. 1999, Klug 2001). They can be identified, although their remains are often only poorly preserved body chambers. M. fecundus is quite widespread in the Tafilalt and Maïder and is clearly distinguishable from other early ammonoid finds (Klug 2001). M. fecundus has been reported from the barrandei and elegans zones in the early Emsian of the Moroccan Anti-Atlas (Alberti 1981, Becker \& House 1994, Klug 2001), but is also known from the late Emsian (Chlupáč \& Turek 1983, Klug 2002, Becker et al. 2004). At Ouidane Chebbi, the first local finds of M. fecundus probably already belong in the elegans Zone (Klug 2001). M. fecundus has also been reported from the sandy upper member of the Mdâour-el-Kbîr Formation (Walliser in Jansen 2001, Becker et al. 2004, Jansen et al. 2007), but these are younger (late Emsian). 


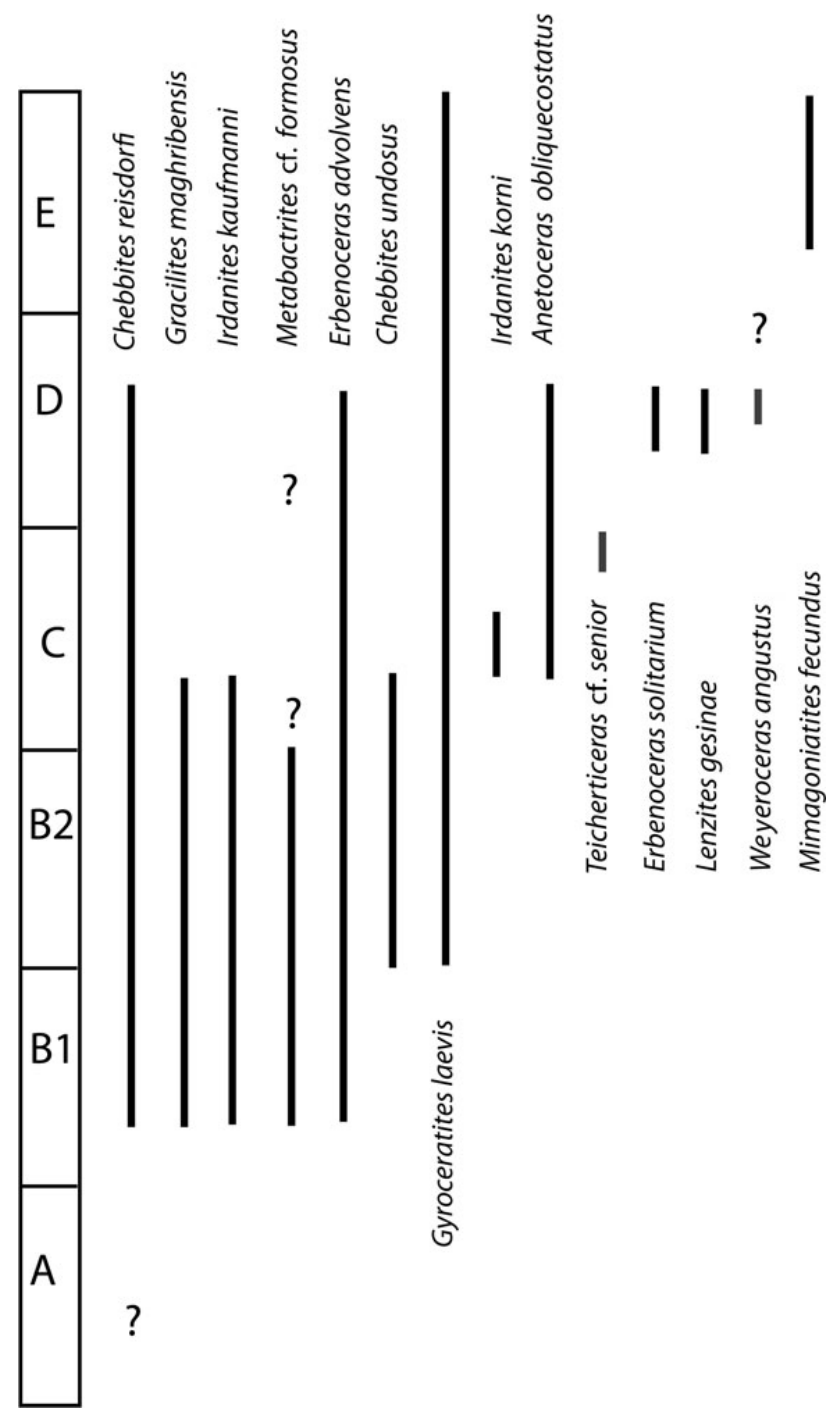

Figure 9. Updated ammonoid ranges in the Moroccan Anti-Atlas (modified from Klug 2001).

The layers with large orthoconic nautiloids might have a certain correlative value as they were found by Kröger (2008) and by us in a similar stratigraphic position at several localities throughout the Tafilalt, from the Ammessoui syncline to the Ouidane Chebbi area (El Atrous/Filon Douce, Gart El Anz, Gara Mdouara, Hamar Laghdad, Ouidane Chebbi). In Ouidane Chebbi, they occur below the first finds of Mimagoniatites fecundus, but in Gara Mdouara and Gart El Anz, they co-occur with M. fecundus. Large orthoconic nautiloids have also been reported from the base of the Khebchia Formation at Bou Tserfine, at Rich Tamelougou in the western Dra Valley and from the Timrhanrhart Formation at Oufrane in the eastern Dra Valley (Becker et al. 2004b, c; Ebbighausen et al. 2004). They are younger (?cancellata to richteri Zone, lower part of the late Emsian) than the ones reported in the Tafilalt (?barrandei-elegans zones, upper part of the early Emsian).
The strata included in the Mdâour-el-Kbîr Formation have been dated as either late Emsian (Hollard 1963a-c, 1965, 1967, 1981a) or early to late Emsian (Hollard 1978, 1981b; Bultynck \& Hollard 1980; Jansen 2001). Our data, which are in accordance with the stratigraphic summaries by Becker et al. (2004d) and Jansen et al. (2007), suggest that the base of the formation is situated in the early Emsian and correlates both with the Deiroceras Limestone and the overlying claystones/marls of the Ouidane Chebbi area. The middle part containing Anetoceras and Lenzites correlates with the Erbenoceras Beds (Unit D). The stratigraphic ranges given by Klug (2001) for the early Emsian ammonoids in the (eastern) Moroccan Anti-Atlas can now be updated (see Fig. 9).

\section{Material and methods}

Most fossil groups from the partially limonitized faunules have already been described in the monograph by Klug et al. (2008). Some additional bactritoids and nautiloids from the limonitized faunules and the Erbenoceras Beds were described or figured by Kröger et al. (2005), Klug (2007) and Kröger (2008). Klug (2001) previously described ammonoids from Faunule 2 and the Erbenoceras Beds. We will focus here on some new ammonoid finds (Anetoceras, Lenzites, Teicherticeras, Weyeroceras) and tabulate corals (Michelinia mdaourensis sp. nov., Petridictyum sp. sensu Plusquellec), which were not previously described in the monograph by Klug et al. (2008).

Descriptive terms for conch shape and ornamentation of ammonoids is adopted from Klug (2001) and Korn \& Klug (2002). Abbreviations of the measured conch dimensions are: $\mathrm{dm}=$ conch diameter, $\mathrm{ww}=$ whorl width, $\mathrm{wh}=$ whorl height, uw = umbilical width and ah = apertural height. Conch shapes are described as follows: thinly discoidal $(\mathrm{ww} / \mathrm{dm}<0.36)$, discoidal $(\mathrm{ww} / \mathrm{dm}=0.36-0.60)$, pachyconic $(\mathrm{ww} / \mathrm{dm}=0.61-0.85)$ and globular $(\mathrm{ww} / \mathrm{dm}=$ 0.86-1.10). Conch dimensions are subdivided as follows: small $(\mathrm{dm}<30 \mathrm{~mm})$, moderate $(\mathrm{dm}=31-70 \mathrm{~mm})$, moderately large $(\mathrm{dm}=71-120 \mathrm{~mm})$, large $(\mathrm{dm}>120 \mathrm{~mm})$. The width of the umbilicus, relative to the diameter of the conch, is termed as follows: very narrow (uw/dm $<0.16$ ), narrow (uw/dm $=0.16-0.30$ ), moderately wide (uw/dm = $0.31-0.45$ ), wide (uw/dm $=0.46-0.60$ ) or very wide (uw/dm > 0.60). The imprint zone rate (IZR) is a ratio which characterizes the whorl overlap. It can be calculated as follows: $\mathrm{IZR}=(\mathrm{wh}-\mathrm{ah}) / \mathrm{ah}$.

The whorl expansion rate (WER) is calculated by the algorithm proposed by Korn \& Klug (2002): WER = [dm / $(\mathrm{dm}-\mathrm{ah})]^{2}$. This method is easier to use, reflects the growth of the soft body during ontogeny and is more appropriate for advolute and gyroconic taxa than the method of Raup \& Michelson (1965). For loosely coiled taxa and advolute taxa, the apertural height equals the whorl height. 
De Baets et al. (2009) introduced two rib indices to quantify and compare rib spacing which are less dependent on coiling than the more usually used parameters, which measure the number of ribs per demi-whorl or per whorl. The new indeces can also be calculated for smaller fragments. The relative rib index (RRI) is the number of ribs on the ventral side within a circle, with a radius equal to the whorl height and centred at the point where the whorl height is measured. The absolute rib index $\left(\mathrm{ARI}_{20}\right)$ is the number of ribs on the ventral side within a circle with a radius equal to $20 \mathrm{~mm}$ and centred at the point where the whorl height is measured. The absolute rib index (ARI) is useful for specimens that have been flattened or in the case when whorl height is not completely measurable, while the relative rib index (RRI) takes account of the ontogenetic change in whorl height.

Descriptive and morphological terms applied to the Micheliniidae are adopted from Plusquellec (2007) and Plusquellec et al. (2007).

All the material figured in this manuscript is deposited in the Paläontologisches Institut und Museum der Universität Zürich (Catalogue Numbers PIMUZ 28379-28453, 28521-28540). Additional plaster casts and acetate peel duplicates of the tabulate corals were deposited in the Laboratoire de Paléontologie, UBO, Brest, cata$\log$ numbers LPB 15327-15341. Ammonoids are described by Kenneth De Baets and tabulate corals by Yves Plusquellec.

\section{Systematic palaeontology}

Class Anthozoa Ehrenberg, 1834

Order Tabulata Milne-Edwards \& Haime, 1850

Family Micheliniidae Waagen \& Wentzel, 1886

Subfamily Micheliniinae Waagen \& Wentzel, 1886

\section{Genus Michelinia De Koninck, 1841}

Type species. - Calamopora tenuisepta (Phillips, 1836) by subsequent designation from the Visean of Yorkshire in the United Kingdom.

\section{Michelinia mdaourensis Plusquellec sp. nov. Figures 10-14}

Holotype. - Specimen figured in Figs 10F, 11M, 13A and 14, PIMUZ 28540, Kenneth De Baets/Christian Klug collection, Paläontologisches Institut und Museum der Universität Zürich.

Type horizon and locality. - Upper part of the MerzâAkhsaï Formation (Faunule 1, ?kitabicus/dehiscens Zone, Lower Emsian), Mdâour-el-Kbîr, Dra Valley (western Anti-Atlas), Morocco.
Material. - Abundant material was collected in Tafilalt and Dra Valley (over 40 specimens); 30 specimens were numbered and are described and/or figured (PIMUZ 28407-28416, 28521-28540), 11 specimens from both areas have been sectioned (PIMUZ 28414, 28525, 28527-28530, 28532, 28533, 28537, 28538, 28540) and 23 thin sections or acetate peels made. The specimens are preserved in calcite, the preservation is rather good, especially the internal structure and microstructure, nevertheless the calices had to be cleaned out and their rims are often partly broken. All specimens derive from Faunule 1 in the Tafilalt (Hassi Tachbit) or its equivalent in the Dra Valley (Mdâour-el-Kbîr). Additional plaster casts and peels LPB 15327-339.

Etymology. - The species is named after the type locality Mdâour-el-Kbîr.

Diagnosis. - Species of Michelinia s.s. with a large variety of growth forms. Corallum having a well developed epithecal side, varying from subcylindrical (Michelinia-like morphotype) to flabelliform (Kerforneidictyum-like morphotype) and a slightly convex calicinal surface with sometimes one or two corallites becoming subcerioid or phaceloid. Size of the corallum ranging from 14 to $30 \mathrm{~mm}$ (in height), 17 to $28 \mathrm{~mm}$ (in width) and 8 to $15 \mathrm{~mm}$ (in thickness). Walls of the calices covered with numerous scattered small spines. Few corallites, often 6 , and never more than 13 or 14 , variable in size with the diameter mostly ranging from 5.5 to $6.5 \mathrm{~mm}$. Tabulae are scarce, tabellae numerous, large or small, clearly convex, generally thin and spaced about 0.2 to $2.5 \mathrm{~mm}$ apart. The wall is spiny, moderately thick, $1.2-1.7 \mathrm{~mm}$ between two adjacent corallites with limited mural pores, belonging to wall pore and angle pore categories; sometimes pore plates. The microstructure of the wall is as follows: median dark line flanked by roughly parallel lamellae and locally some areas where they are diverging upwards; numerous trabeculae. Earliest stage of growth of the corallum with two corallites having more or less the same diameter, one of them being the protocorallite. Hicetes always present.

Description. - The corallum displays a large range of growth forms, but all the specimens share some morphological features such as: a massive corallum, cerioid, but sometimes with some corallites becoming subcerioid to phaceloid in its very distal part (Fig. 11B, J), an external wall covered by transverse growth wrinkles or ridges (i.e. the "epitheca"), some longitudinal furrows corresponding to the boundary of corallites and, on uneroded surfaces, numerous smooth longitudinal furrows and ridges probably linked to the septal ridges. The transverse outline of the corallum is more or less lobate and flattened depending on the morphotype. The calices are usually wider than deep and 
their rim narrow, their walls covered with numerous scattered small spines (Fig. 12C) and possibly, in rare cases, set in roughly longitudinal rows (see the natural casts of deeper part of the wall in Fig. 10F, Q). The calicinal bottom shows some small convex areas induced by the tabellae filling the corallite.

Morphotypes. - The colonies of Michelinia mdaourensis from Tafilalt and Dra display several morphotypes in which we can distinguish two extreme habitus here called the Michelinia-like morphotype and Kerforneidictyumlike morphotype; between them a set of "intermediate" morphotypes can be recognized:

Michelinia-like morphotype. In this morphotype the corallum is tall, elongate and usually has a height/width ratio of about 1.5. The corallites are subcylindrical, subparallel and somewhat sinuous (Fig. 11B, C) or slightly to moderately divergent, all reaching the distal surface of the colony except in rare cases. The transverse outline of the corallum at the calicinal level is slightly (Fig. 11A) to markedly flattened (specimen of Figs 10O, P, 11N), more or less regularly lobate (Fig. 11A) to asymmetrically lobate. In side view, i.e. parallel to the plane of flattening, the longitudinal outline is generally curved. The holotype (PIMUZ 28540) is of this morphotype (see Figs 10F, 11M).

Kerforneidictyum-like morphotype. In this type the corallum is flabelliform, either slightly taller than wide (slender form $=$ Fig. $11 \mathrm{G}, \mathrm{H}, \mathrm{I}$; height/width ratio 1.1 ) or wider than tall (stocky form $=$ Figs $10 \mathrm{G}, \mathrm{H}, 11 \mathrm{~J}-\mathrm{L}$; height/width ratio respectively 0.7 and 0.6 ). Its transverse outline at the calicinal level is strongly flattened and sometimes shows an imperfect bilateral symmetry (Fig. 11J), occasionally a marked median constriction. In the plane of flattening the corallites are clearly divergent (Fig. 11H, K) and, in side view, they are generally straight.

"Intermediate" morphotype. In this type the corallum is usually taller than wide (height/width ratio of between 1.2-1.4) and the corallites are fairly to slightly divergent. The transverse outline of the corallum at the calicinal level is moderately flattened (Fig. 10M), nevertheless some specimens develop a protuberant corallite on the concave side of the corallum (Fig. 11D) which gives them a strongly lobate appearance to one side of the transverse outline.

The Michelinia-like morphotype seems to be more frequent in the Dra Valley than in the Tafilalt, whereas the Kerforneidictyum-like morphotype is not recorded in the Dra. The "intermediate" morphotype is known in the Dra as well as in the Tafilalt, including the "intermediate" morphotype with a protuberant corallite.

Structure of the corallum. - The horizontal skeletal elements, tabulae and tabellae, well exposed in longitudinal sections, fill the lumen from the bottom of the corallite up to the calice; thus the possibly massive proximal part of the corallum is very reduced or lacking (see Figs 12, 13). The tabulae are scarce, flat or slightly upwardly arched while the tabellae are numerous, large or small, with the edge resting either on the wall or on one another. The distribution of the tabellae does not allow the distinction of a peripheral zone in the corallite and the flying buttress type is extremely scarce. Tabulae or tabellae, thin or sometimes moderately thickened, bear some small spines as is usual in the Micheliniidae.

The walls are moderately thick, spiny, but no true septal ridges can be seen in section. The mural pores are scarce, but wall pores $\left(\mathrm{P}_{2}\right)$ and angle pores $\left(\mathrm{P}_{1}\right)$ have been identified (Fig. 13D); pore plates are present.

The Hicetes tube is present from an early stage of growth in each colony, and its two rounded apertures generally open onto the calicinal side (Fig. 11D, J). In some specimens only one aperture can be seen between the calices (Fig. 11G) or in a transverse section (Fig. 13C); this is very unusual. The explanation is that one opening may be anomalously situated in the very proximal part of the corallum and probably bores through the wall (this situation is exposed in a specimen from Mdâour-El-Kbîr).

Microstructure. - The wall between neighbouring corallites consists of a broken median "dark" line flanked on each side by a stereoplasm of lamellae. In longitudinal section they are mainly parallel to the median line (Fig. 14). Nevertheless in some rather thick parts of the wall the lamellae

Figure 10. Early Emsian Tabulate corals (Michelinia mdaourensis sp. nov.) from Faunule 1 of Hassi Tachbit (Tafilalt) and Mdâour-El-Kbîr (Dra region); calinical (A, G, I), "epithecal" or side views (B, D, F, H, K, N, O, P, Q, R, T) and bottom views (C, E, L, M, S). • A-C - Kerforneidictyum-like morphotype on Palaeozygopleura vaneki Frýda et al., 2008; PIMUZ 28407. • D, E - "intermediate" morphotype on Nucoloidea grandaeva (Goldfuss, 1840); PIMUZ 28409. • F - Michelinia-like morphotype; see on left the corallite "b" of Fig. 10M with its free distal part, on top right the corallite "d", and on bottom right the corallite "a" broken and partly in natural cast; holotype PIMUZ 28540. • G, H - Kerforneidictyum-like morphotype on Palaeozygopleura vaneki Frýda et al., 2008; PIMUZ 28410. • I, J - unidentified morphotype on ?crinoid; PIMUZ 28412. • K, L - unidentified morphotype on Metacanthina wallacei (Termier \& Termier, 1950c); PIMUZ 28411. • M, N - "intermediate" morphotype on Orthocycloceras sp.; PIMUZ 28408. • O, P - Michelinia-like morphotype on Palaeoneilo cf. emarginata (Conrad, 1841); O side adb, P side abc (see Fig. 10O); PIMUZ 28414. • Q - unidentified morphotype on orthoceratid; PIMUZ 28415. • R, S - Kerforneidictyum-like morphotype on ?Spyroceras sp.; PIMUZ 28416. - T - "intermediate” morphotype on rugose coral, gen. et sp. indet.; PIMUZ 28413. • A-E, G-N, R-S - Hassi Tachbit; Seheb El Rhassel Group, Unit B3 of Bultynck \& Walliser 2000a, b (Faunule 1). • F, O-Q, T - Mdâour-El-Kbîr; Merzâ-Akhsaï Formation (Faunule 1). All specimens $\times 2$, except D, E and I, J $\times$ 3. Specimens whitened with ammonium chloride. 
Kenneth De Baets et al. • Zlíchovian faunas with early ammonoids, Anti-Atlas
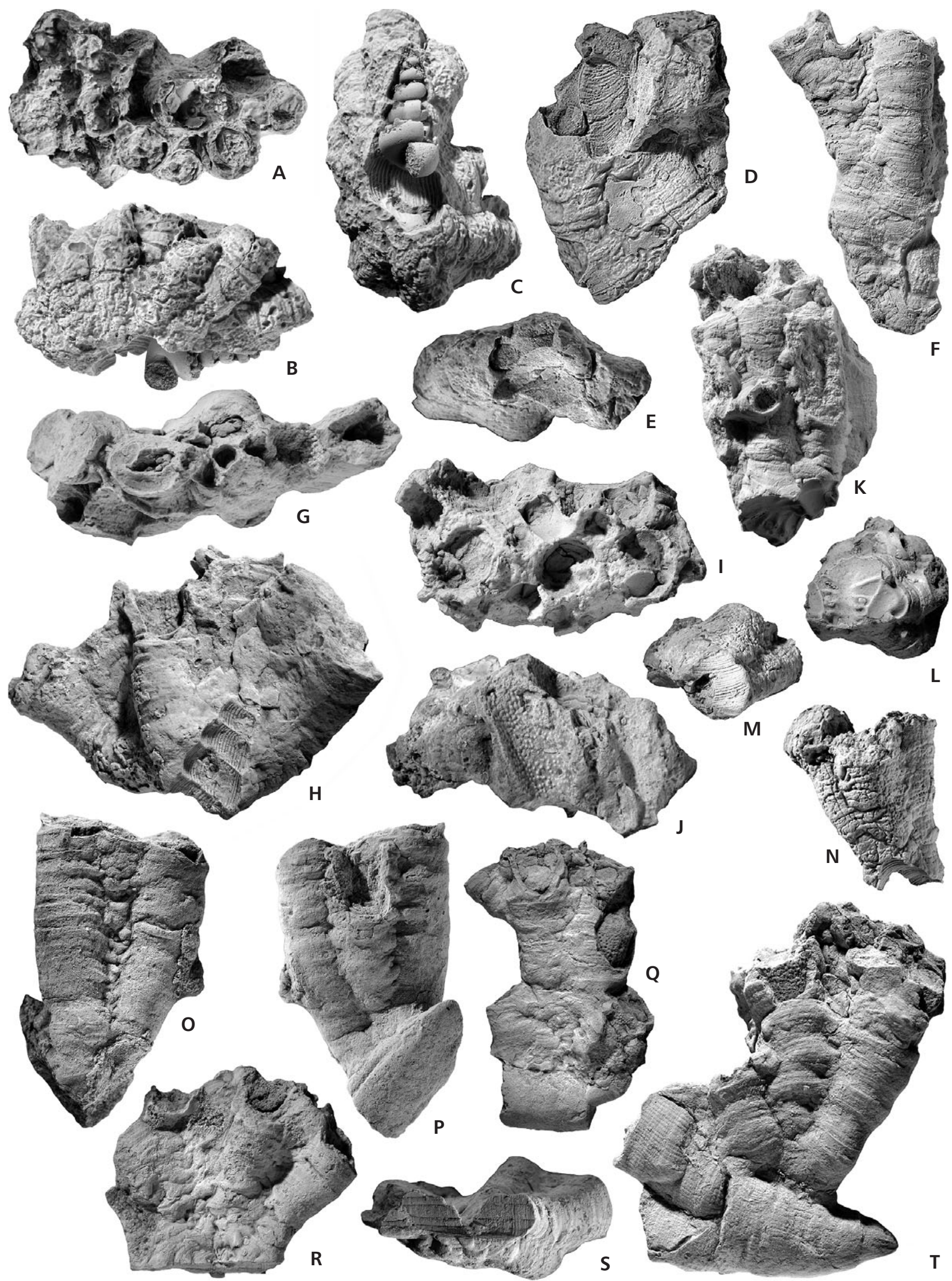
are oblique to the median line and upwardly diverging. This feature was previously described in Michelinia meekana Girty, 1910 by Plusquellec \& Sando (1987). Numerous trabeculae, giving rise to spines as they emerge from the stereoplasm in the lumen of the corallite and around which the lamellae are deflected, are noticeable in the whole corallum.

Increase of corallum. - In the earliest stage of growth two opposite corallites with more or less the same diameter soon develope. One of them is the protocorallite, but it is impossible to identify it without the aid of serial acetate peels. The other is the first metacorallite; in the figures they are labelled $\mathbf{a}$ and $\mathbf{b}$, but without any parental significance (Fig. 11). This first stage is followed by the appearance, between $\mathbf{a}$ and $\mathbf{b}$ and on one side of the corallum, of a third corallite labelled $\mathbf{c}$; its proximal tip is close to the basal surface of the corallum (Fig. 11E, H). Thus we can define a side abc which is often convex in transverse section. A section of this stage is figured (Fig. 13C). The fourth corallite appears between $\mathbf{a}$ and $\mathbf{b}$, but a little bit later and on the other side of the corallum (Fig. 11F, I); corallite $\mathbf{d}$ is facing $\mathbf{c}$ (Fig. 11G, O). At this stage of development a transverse section of the corallum is often convex on side abc and is cross-shaped in form (see "section" in Fig. 11O). In this paper the following stages are not labelled but in Fig. 11E it is easy to identify the metacorallites, $\mathbf{e}$ and $\mathbf{f}$, appearing nearly simultaneously.

In this type of increase, the protocorallite is situated on one side of the corallum in the plane of flattening, and all of the metacorallites on the other side (see for instance Fig. $11 \mathrm{G}$ where if $\mathbf{a}$ is the protocorallite the metacorallites $\mathbf{b}, \mathbf{c}$ and $\mathbf{d}$ are situated on its right side). This is similar to the sequence referred to by Webb (1993, fig. 5) in Palaeacis snideri (Mississippian). In Kerforneidictyum, the protocorallite remains in the axis of the corallum and the first pair of metacorallites appear one on either side of it (Plusquellec \& Hladil, 2001, fig. 4). Note that Plusquellec (2007, p. 59) erroneously wrote that the type of increase is similar in Kerforneidictyum and Palaeacis.

Measurements. - Height of corallum: 14.5 (Kerforneidictyum-like morphotype) - $30 \mathrm{~mm}$ (Michelinia-like mor- photype). Width or maximum corallum diameter: 17 (Michelinia-like morphotype) - $28 \mathrm{~mm}$ (Kerforneidictyum-like morphotype). Thickness or minimum corallum diameter: mainly $8-13 \mathrm{~mm}$, but up to $15.5 \mathrm{~mm}$ ("intermediate" morphotype with protuberant corallite d). Angle of divergence of the protocorallite with the first metacorallite in the plane of flattening: $30^{\circ}$ (Michelinia-like morphotype) $-80^{\circ}$ (Kerforneidictyum-like morphotype). Maximum corallite diameter (i.e. including the wall): usually 5.5-6.5 mm, but up to $7.5 \mathrm{~mm}$. Thickness of the "epithecate" wall: $0.5-0.6 \mathrm{~mm}$, thickness of the wall between two adjacent corallites: $1.2-1.7 \mathrm{~mm}$. Distance between consecutive tabulae and/or tabellae: variable, $0.2-2.5 \mathrm{~mm}$. Pore diameter: about $0.3-0.5 \mathrm{~mm}$. Hicetes diameter: usually 2.0-2.2 $\mathrm{mm}$.

Remarks. - Regardless of global morphology, all specimens show roughly the same corallum and corallite size, the same trend for some of them to be free (subcerioid), the same granular ornamentation of the calices, the same setting of tabulae and tabellae, the same comparative scarcity of mural pores, the same thickness of the wall, the same microstructure and the constant presence of Hicetes. Hence we conclude that all the specimens belong to the same species, which displays a panel of several morphotypes. Comparable, but less extreme variations, have been previously described in the Givetian within "Pleurodictyum" americanum by Pandolfi \& Burke (1989).

Owing to the structure of the corallum, particularly to the numerous upwards arched tabellae, the two kinds of mural pores and the microstructure of the wall (lamellae mainly parallel to the median line), the colonies from the Tafilalt and the Dra are assigned to the genus Michelinia; see also in Lafuste \& Plusquellec (1985) the distinctive characteristics of Michelinia De Koninck, 1841, Praemichelinia Lafuste \& Plusquellec, 1980 and Turnacipora Lafuste \& Plusquellec, 1985.

Despite the flattening and the flabelliform habitus of some morphotypes, our specimens differ from Kerforneidictyum Lafuste \& Plusquellec, 1976 by the strong development of tabulae and tabellae, the lack of a massive/compact skeleton in the proximal part of the corallum and the type of increase. In addition, the transverse as well

Figure 11. Morphology of Michelinia mdaourensis sp. nov. Calicinal (A, D, G, J, M-O) and "epithecal” views (B, C, E, F, H, I, K, L) of the corallum. The four first corallites are "numbered" abcd (see explanations in text). A, B, C-Michelinia-like morphotype (see transverse section Fig. 12D, black arrow on Fig. 10B indicates the position of this section); PIMUZ 28527. • D, E, F - intermediate morphotype with prominent corallite "d"; PIMUZ 28523. - G, H, I - Kerforneidictyum-like morphotype showing the convex transverse outline of side abc, and the concave outline on side abd; note that only one opening of the Hicetes tube is known on the calicinal surface (see transverse section Fig. 13C); PIMUZ 28533. • J, K, L - Kerforneidictyum-like morphotype, more stocky than the former; PIMUZ 28532. $\bullet \mathrm{M}$-Michelinia-like morphotype, in addition to the two openings of the Hicetes there are two small openings of another organism (see "epithecal" views in Fig. 9F); holotype PIMUZ 28540. • N - Michelinia-like morphotype, flat specimen; PIMUZ 28538. $• \mathrm{O}$-Michelinia-like morphotype, note cross pattern of the four first corallites (see "epithecal" views in Fig. 9O, P); PIMUZ 28414. • A-L - Hassi Tachbit; Seheb El Rhassel Group, Unit B3 of Bultynck \& Walliser 2000a, b (Faunule 1) • M-O - Mdâour-El-Kbîr; upper part of the Merzâ-Akhsaï Formation (Faunule 1). 
Kenneth De Baets et al. • Zlíchovian faunas with early ammonoids, Anti-Atlas
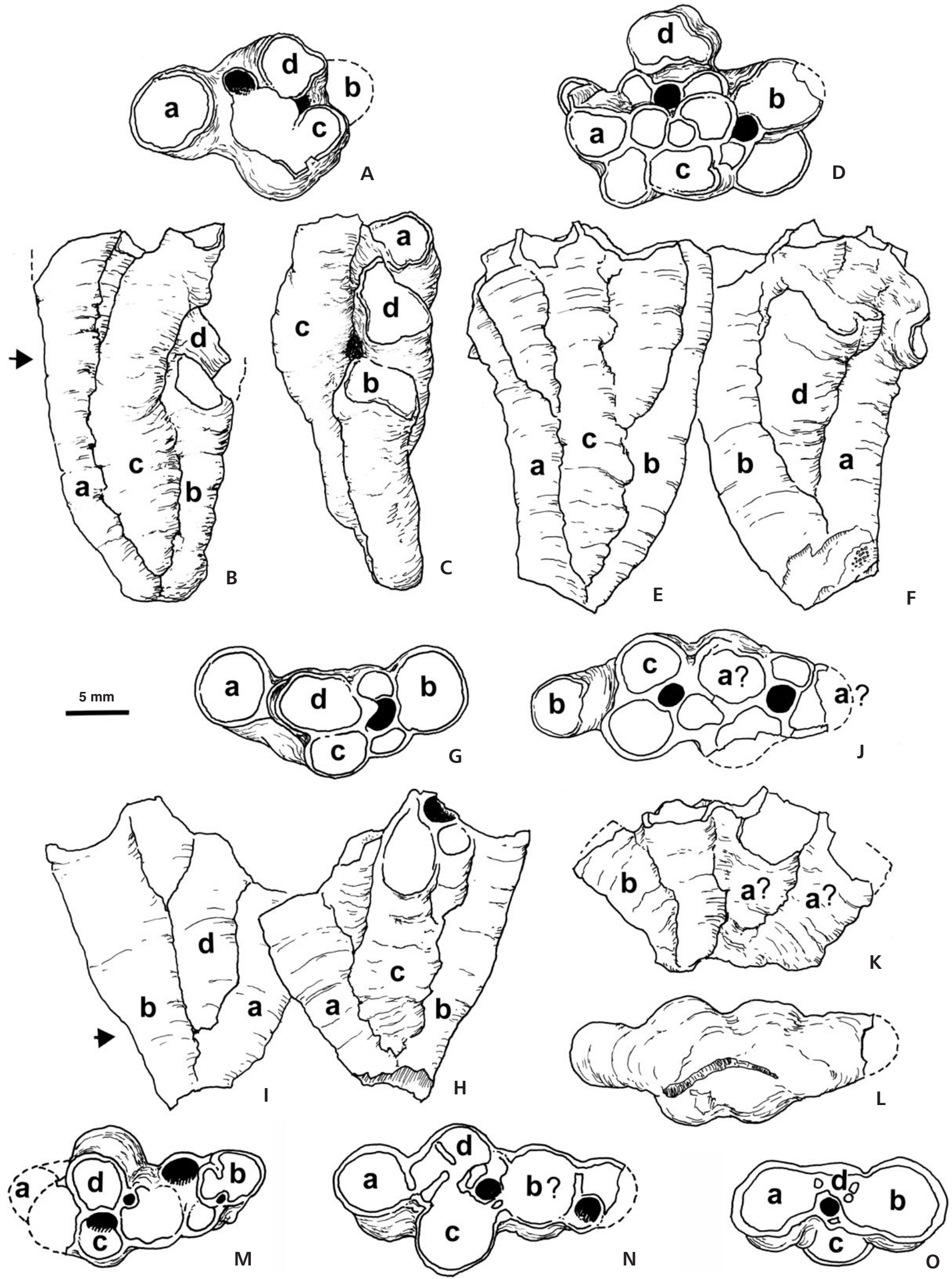


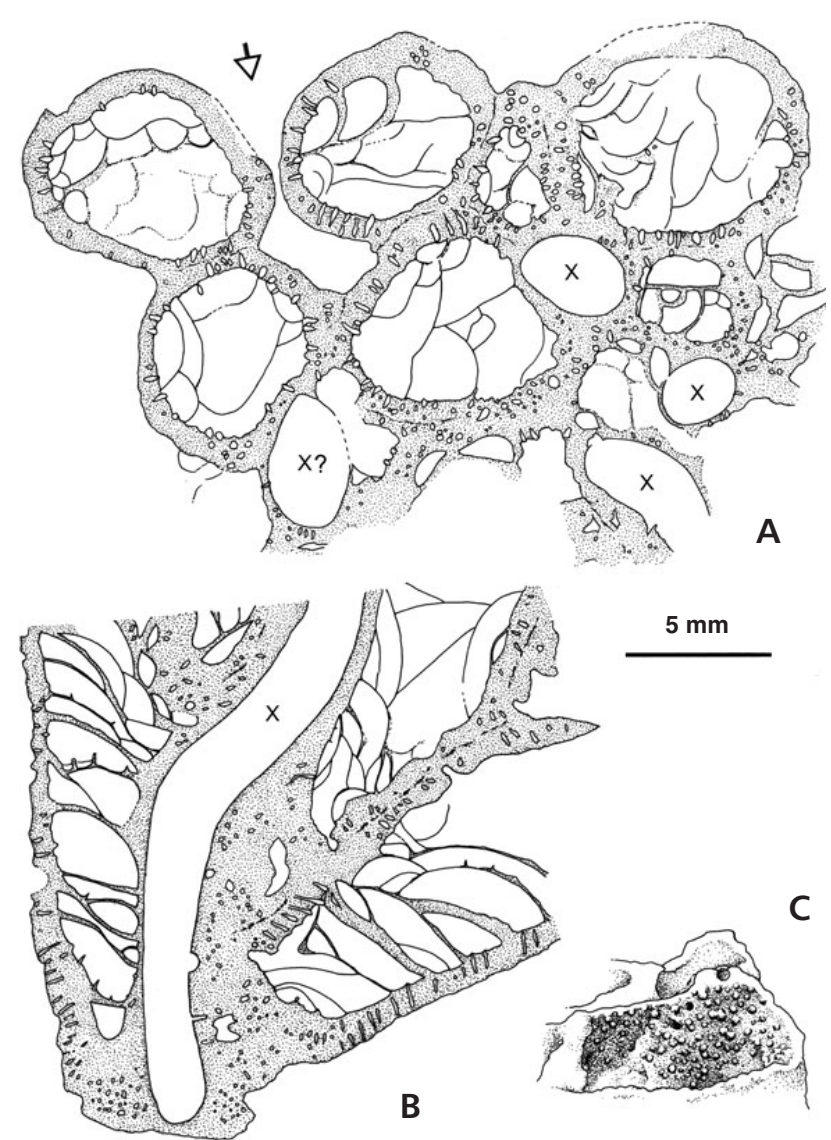

Figure 12. Structure of Michelinia mdaourensis sp. nov., camera lucida drawing from thin section; probably "intermediate" morphotype, but unfortunately no cast was made before sawing the specimen; PIMUZ 28530; Hassi Tachbit; Unit B3 of Bultynck \& Walliser 2000a, b (Faunule 1 of Klug et al. 2008). • A - transverse section in the distal part of the corallum showing the numerous trabeculae in the wall of the corallites, sections through tabulae and tabellae and the sections of the Hicetes tube marked by " $x$ ". Note the lack of mural pores in this section. Arrow in the upper left part indicates the subceroid trend of the corallum. • B - longitudinal section showing some flat or upwards arched, thickened tabulae and numerous tabellae, some of them with spines. $\bullet \mathrm{C}$ - oblique view of the wall of a calice showing the numerous scattered small spines and some mural pores.

as longitudinal sections or outlines are not arched in Kerforneidictyum.

The Michelinia from the early Emsian of Tafilalt and Dra is very likely a new species. In fact the genus Michelinia, clearly identified by its structure and microstructure, is very scarce in the Early Devonian. As far as we know, it is only recorded in Spain, Algeria and probably in Australia.

Plusquellec (2007, p. 60, fig. 32) briefly described and figured some specimens from the La Pedrosa Formation, early Emsian in Spain, Cantabrian Zone, León. The colonies are small, slightly flattened, more or less flabelliform, "epithecate" and associated with Hicetes. Therefore this material shares several features in common with that from
Tafilalt and Dra, especially with the Kerforneidictyum-like morphotype. Nevertheless it differs in having a less lobate outline in transverse section, smaller corallites (diameter 4-5 mm), a less thick wall, more tabulae and less tabellae. Clearly they are two different species.

The Cantabrian specimens were collected from the lowermost part of the La Pedrosa Formation with Pilletina collensis in the localities Colle and La Vid.

According to García-Alcalde (1997, fig. 2) the boundary between the underlying Felmín Formation and the La Pedrosa Formation is within the early Emsian and coincides with the Basal Zlíchov Event (BZE). Furthermore, the boundary between Le Faou Formation and Reun ar C'hrank Formation (Armorican massive, Rade de Brest) is correlated with the Felmín Formation/La Pedrosa Formation and in the Rade de Brest, the BZE is situated in level F12 (García-Alcalde 1997, p. 242). This level is the uppermost part of the Le Faou Fm. (Le Menn et al. 1976) and is attributed to the top of the dehiscens Zone (Plusquellec 1993, p. 114 and fig. 15). In addition the lower part of the La Pedrosa Formation is situated below the Middle to Upper $P$. excavatus Zone (Garcia-Lopez \& Sanz-Lopez 2002).

Hence, the specimens from Colle and La Vid could be of about the same age as those from Tafilalt and Dra.

In the Ougarta area, western Sahara (Algeria), the genus is known in the late Emsian, Teferguenit Formation in two localities, $\mathrm{ZH} 52$ and LK 92 (Plusquellec in Boumendjel et al. 1997, tab. 3, Michelinia sp. no descriptions) and probably from the "coral bearing level", Lower Chefar El Ahmar Formation, late Emsian, described by Le Maître as Michelinia (Ethmoplax) fascialis (1952, pp. 80-82, pl. 4, figs 3-8) and later as Holacanthopora fascialis (1954, unnumbered fig.). Michelinia sp. from $\mathrm{ZH}$ 52 (one specimen) is a small spherical species with corallites up to $8 \mathrm{~mm}$ in size and with very numerous tabellae. Michelinia sp. from LK 92 (2 specimens) is a more or less ramose species devoid of "epitheca", with small corallites (4 mm) showing numerous tabulae and closely spaced tabellae. Michelinia fascialis is not well known, but it is a rather large species (corallum up to $76 \mathrm{~mm}$, mean diameter of corallites $7 \mathrm{~mm}$ ) with less abundant tabellae than Michelinia sp. nov.

In Australia, the so-called Holacanthopora clarkei Wright \& Flory, 1980, from the late Emsian Mount Frome Limestone Formation, seems to be more similar to Michelinia than to Praemichelinia. It is a large, approximately spherical species and up to at least $12 \mathrm{~cm}$ in diameter, devoid of "epitheca"; in addition the corallites are numerous, polygonal and the angle pores frequent. None of the species from Ougarta and New South Wales are associated with Hicetes.

Michelinia mdaourensis sp. nov. seems to be the first representative, or one of the two first representatives, of the 

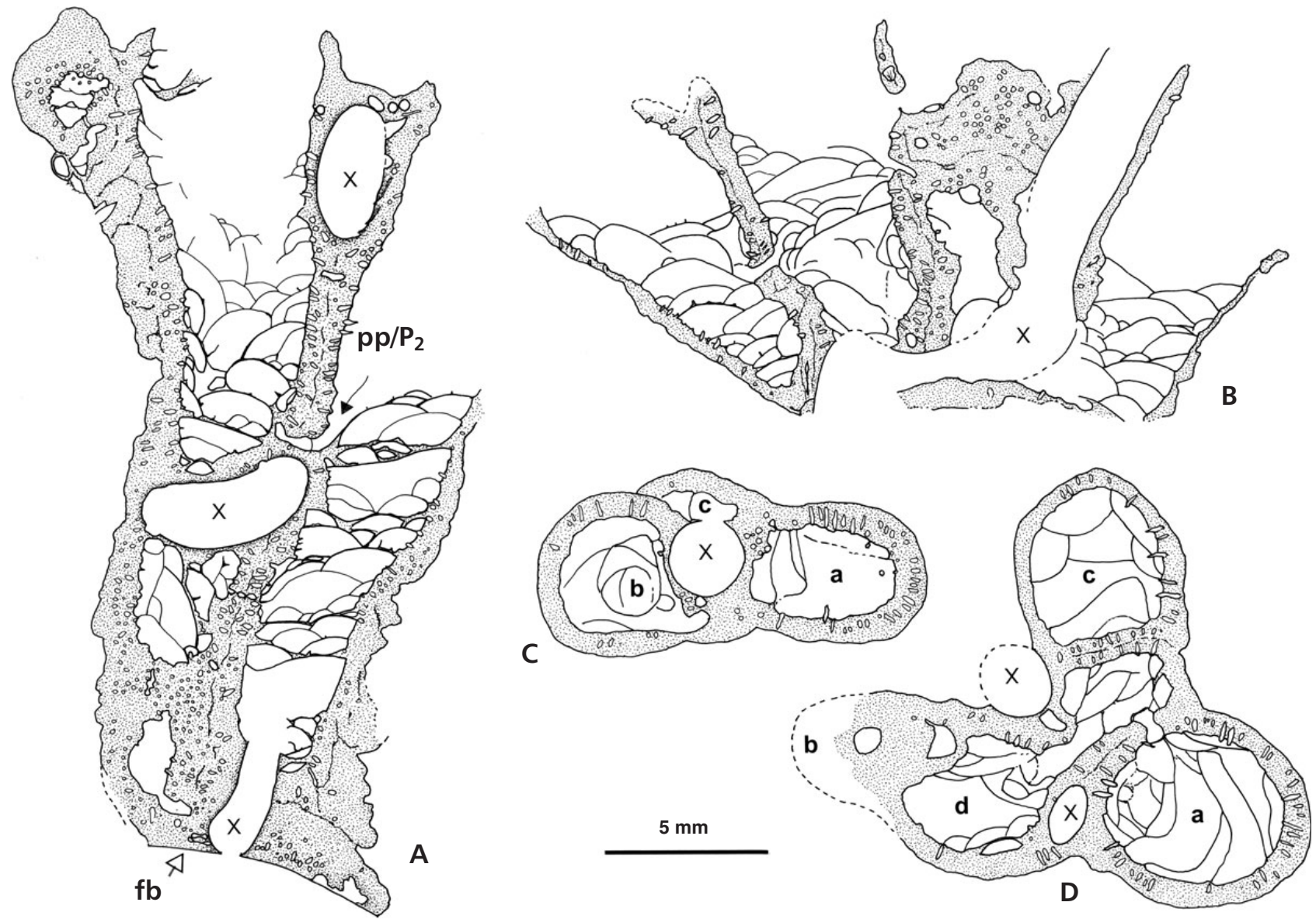

Figure 13. Structure of Michelinia mdaourensis sp. nov., camera lucida drawing from thin section (A, B) or acetate peel (C, D). $\bullet$ A - Michelinia-like morphotype; longitudinal section showing numerous tabellae, a mural pore (likely wall pore) with a pore plate $\left(\mathrm{pp} / \mathrm{P}_{2}\right)$ and the scar of a foreign body on which the corallum was attached (fb, open arrow); holotype PIMUZ 28540. • B - Kerforneidictyum-like morphotype; longitudinal section showing tabellae very similar to those in Fig. 13A; PIMUZ 28532. $\bullet \mathrm{C}-$ Kerforneidictyum-like morphotype, transverse section from the proximal part of the corallum showing the first three corallites and one section only from Hicetes; Hassi Tachbit (Faunule 1); PIMUZ 28533. • D - Michelinia-like morphotype: transverse section of the early distal part of the corallum, note a corner pore in the upper right of corallite $\mathbf{d}$ and a wall pore in the upper left of corallite a; PIMUZ 28527. • A - Mdâour-El-Kbîr; upper part of the Merzâ-Akhsaï Formation (Faunule 1). • B-D - Hassi Tachbit; Seheb El Rhassel Group, Unit B3 of Bultynck \& Walliser 2000a, b (Faunule 1).

genus Michelinia and, in both cases, the genus appears to have a northern Gondwanian origin. In addition, the first appearance of the Kerforneidictyum-like morphology is situated within the dehiscens Zone of Tafilalt, while the first occurrence of the genus Kerforneidictyum appears to be at the top of the dehiscens Zone in Kellerwald, the Giessen-Harz nappe of the Rhenish Mountains (Plusquellec \& Jahnke 1999). Taking into account that the accurate stratigraphical position of $K$. oeslingensis Plusquellec \& Franke, 2010 within the early Emsian of the Ardenno-Rhenish Mountains of Luxembourg is not well known, the fossil record for Kerforneidictyum remains rather conjectural.

Occurrence. - Finds are restricted to the early Emsian of the Moroccan Anti-Atlas. In the Tafilalt, fossil material was weathered out of the marls below the Deiroceras Li- mestone (dehiscens Zone). The specimens from the western Anti-Atlas (Mdâour-El-Kbîr) derive from a single horizon in the upper Merzâ-Akhsaï Formation. The same forms probably come from a similar stratigraphical interval in the Tafilalt. However, these were loosely collected specimens weathered from claystones and marls, so this can be verified only indirectly using associated fauna, which are very similar (Metacanthina, Nahecaris, paleotaxodont bivalves and others). At least two horizons with limonitic fauna have been found in the Ouidane Chebbi area within the marls intercalated between the Deiroceras Limestone and "Pragian" Limestone.

Paleoecology. - The corals which had an epibenthic mode of life have been found fixed to foreign bodies, bivalves (Fig. 10D, E, O, P), other corals (mostly solitary rugose forms; Fig. 10T), crinoids? (Fig. 10J), gastropods (Palaeo- 


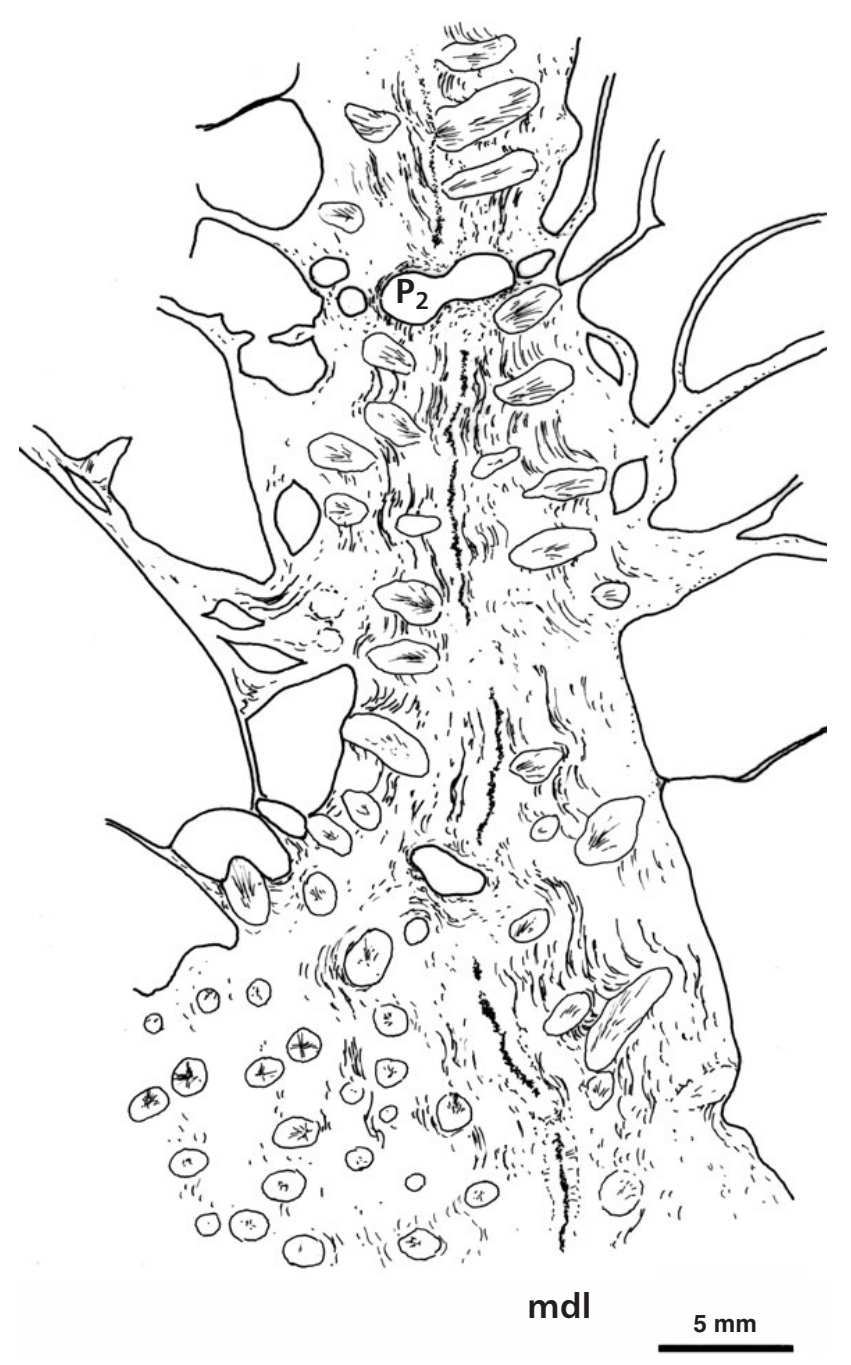

Figure 14. Microstructure of Michelinia mdaourensis sp. nov., camera lucida drawing from a $30 \mu \mathrm{m}$ thin section. Longitudinal section from the wall showing the median "dark" line (mdl), the lamellae mainly parallel to this structure and the numerous trabeculae appearing in longitudinal section in the upper part of the figure and in transverse section in the lower left part. Note at the top of the figure, a small area with upward diverging lamellae. In addition one can see the peripheral part of the tabulae and tabellae and a section through a mural pore (likely wall pore $\mathrm{P}_{2}$ ); holotype PIMUZ 28540. Hassi Tachbit; Seheb El Rhassel Group, Unit B3 of Bultynck \& Walliser 2000a, b (Faunule 1). zygopleura; Fig. 10C, H), orthoconic nautiloids (Fig. 10Q, M, N, R, S) and trilobites (Metacanthina; Fig. 10L). Gastropods were previously only known as internal moulds, but now two external moulds of the shell surface of Paleozygopleura have been found at the base of Michelinia-colonies (PIMUZ 28407, 28410; see Fig. 10C, H). These can now be assigned to Palaeozygopleura vaneki Frýda et al., 2008.

\section{Genus Petridictyum Schindewolf, 1959}

Type species. - Pleurodictyum petrii Maurer, 1874 by subsequent designation from the Early Devonian of Giessen nappe in Germany.

Petridictyum sp. sensu Plusquellec, 2007

Figure $15 \mathrm{~S}, \mathrm{~V}, \mathrm{~W}, \mathrm{X}$

2007 Petridictyum sp.; Plusquellec, figs 23, pl. 2, fig. 3.

Material. - Two specimens, one specimen from Hassi Tachbit, the other one from Oum El Jerane (Tafilalt), both preserved in calcite. Both specimens derive from Unit B3 of Bultynck \& Walliser 2000a, b (Faunule 1 of Klug et al. 2008), probably the dehiscens/kitabicus Zone. Specimens PIMUZ 28426-28427 and plaster casts LPB 15340-341.

Description. - The proximal side shows an impression of a foreign body to which the coral is fixed by its base, surrounded by concentric growth ridges: the so-called epitheca. The outline of the corallum is more or less lobate, especially in the adapical area (see top of Fig. 15X).

In side view, the proximal side of the corallum is strongly convex, in particular unusually convex in the specimen from Hassi Tachbit (Fig. 15S), however its distal surface is distinctly less so. Height of the corallum is between $6.3 \mathrm{~mm}$ and $8.5 \mathrm{~mm}$.

The distal or calicinal side shows a large central corallite (= protocorallite) surrounded by a corona of 5 or 6 metacorallites. Diameter of corallum normal to the plane of

Figure 15. Bivalves and corals from the early Emsian of Mdâour-El-Kbîr (Dra region) and various localities in the Tafilalt. Bivalvia. • A, B - Lunulacardiidae gen. et sp. indet.; lateral views of right and left valve, $\times 3$; PIMUZ 28417. $\bullet$ C, D - Phestia rostellata (Conrad, 1841); lateral and dorsal views, $\times 3$; PIMUZ 28418. • E, F, G - ?Nuculopsis sp., ventral, lateral and dorsal views, $\times 3$; PIMUZ 28419. • H, I - Palaeoneilo emarginata (Conrad, 1841); lateral and dorsal views, $\times 3$; PIMUZ 28420. $\bullet$ J, K -Nuculoidea sp.; lateral and dorsal views, $\times 4$; PIMUZ 28421. • L, M, R, Z - Nuculoidea grandaeva (Goldfuss, 1840); lateral views (except Z: dorsal view). L - × 2; PIMUZ 28424. M - × 3, PIMUZ 28450. R, Z - × 4; PIMUZ 28425. • N, O - Cuculella triquetra (Conrad, 1841); lateral and dorsal views, $\times 3$; PIMUZ 28423. • P, Q - Palaeoneilo sp.; lateral and dorsal views, $\times 2$; PIMUZ 28422. Corals. - S, V, W, X - Petridictyum sp. sensu Plusquellec (2007). S, X - side view showing the apical area and calicinal view with adapical area at the top of the figure, $\times 3$; PIMUZ 28426. V, W - calicinal view with adapical area at the top of the figure and side view showing the apical area, $\times 3$; PIMUZ 28427 . - T, U, Y, AA - rugose corals, gen. et sp. indet.; Faunule 1. T, Y - calix and lateral view, × 3; PIMUZ 28428. U, AA - calix and lateral view, × 2; PIMUZ 28429. • A, B - Mdâour-El-Kbîr; Mdâour-El-Kbîr Formation (Faunule 2). • C-R, T, Y, Z - Mdâour-El-Kbîr; Merzâ-Akhsaï Formation (Faunule 1). - S, U, X, AA - Hassi Tachbit; Seheb El Rhassel Group, Unit B3 of Bultynck \& Walliser 2000a, b (Faunule 1). • V, W - Oum El Jerane; Unit B3 of Bultynck \& Walliser 2000a, b (Faunule 1). All specimens whitened with ammonium chloride. 
Kenneth De Baets et al. • Zlíchovian faunas with early ammonoids, Anti-Atlas

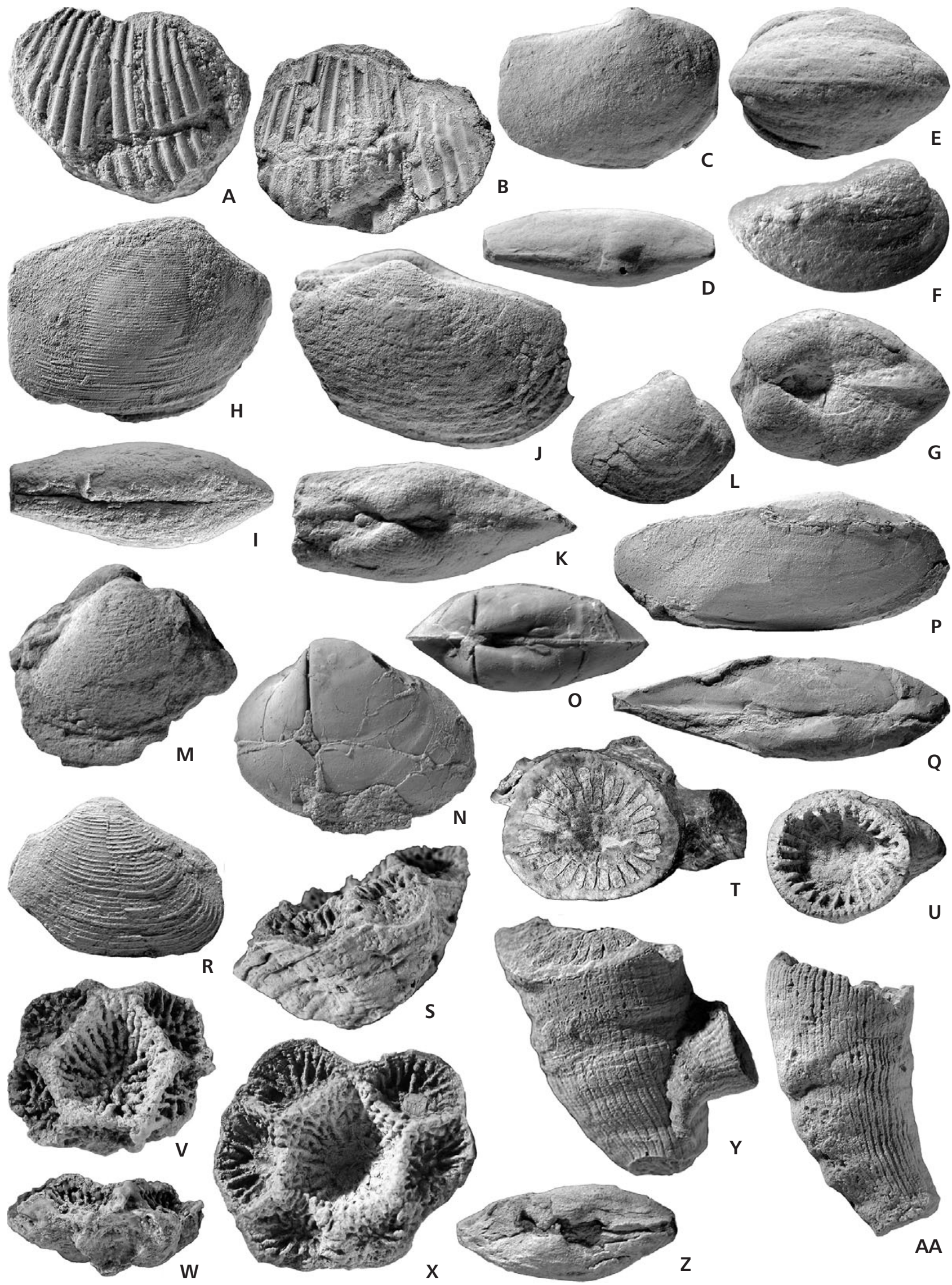


symmetry (i.e. E-W on Fig. $15 \mathrm{~V}, \mathrm{X}$ ) is $12.5 \mathrm{~mm}$ and $15.8 \mathrm{~mm}$

The protocorallite is deep and its walls bear numerous septal ridges (about 34 and 35-36); major and minor ridges cannot be easily distinguished due to their similar lengths. In the axial part (bottom) of the protocorallite, the ridges become less continuous and somewhat irregular. Scattered mural pores are situated either on the ridges or between them in the furrows (diameter of pores $0.2-0.25 \mathrm{~mm}$ ).

The metacorallites are less deep than the protocorallite, and on their peripheral margin the major and minor septal ridges are clearly exposed. On the peripheral margin of the metacorallites 9 to 13 (usually 12) septal ridges are exposed. The calicinal bottom of the metacorallites shows an irregular and more or less reticulate structure produced by the proximal part of the ridges (Fig. 15V). The ridges of both protocorallite and metacorallites bear spines, often erroded.

Remarks. - The specimens from the Tafilalt share numerous morphological features with Petridictyum sp. figured by Plusquellec (2007, fig. 23 and pl. 2, fig. 3) and collected by Hollard in the Dra Valley from the middle member of the Merzâ-Akhsaï Formation (early Emsian according to Hollard 1981b) and thus, very likely, belong to the same species. Nevertheless, the irregular to reticulate septal structure exhibited at the calicinal bottom is more marked in Hollard's specimen, but this can be due to poorer preservation or eolian erosion of the material from Tafilalt.

This species clearly differs from the previously described ones such as $P$. petrii (Maurer, 1874), P. lenticulare (Hall, 1874), P. lonsdalii (Richter, 1855), P. casanovai Plusquellec \& Soto in Plusquellec et al. (2007) and P. erbslochensis Plusquellec \& Jahnke nom. nud. (cf. Plusquellec 2007, pl. 2, fig. 2). Thus the species seems to be new, but further material will be necessary to determine if certain "diagnostic" characters are consistently maintained.

Petridictyum sp. sensu Plusquellec (2007) from Dra and Tafilalt is, as far as we know, the first representative of the genus in North Africa. Nevertheless the genus is known from North Gondwana (Ossa Morena and Catalonian Coastal Ranges, Spain), from the Late Lochkovian or Early Pragian onwards (P. casanovai).
Occurrence. - The taxon is so far restricted to the early Emsian (and maybe also the late Pragian) of the Moroccan Anti-Atlas. It was found in the marls (Unit B3 of Bultynck \& Walliser 2000a, b) intercalated between the "Pragian Limestone" and the Deiroceras Limestone (dehiscens conodont Zone) of the Tafilalt in the eastern Anti-Atlas (Hassi Tachbit). The specimens from the western Dra Valley derive from the middle part of the Merzâ-Akhsaï Formation, probably early Emsian (Hollard 1981b, Plusquellec 2007) or still late Pragian (Schraut 2000, Jansen 2001, Becker et al. 2004, Jansen et al. 2004).

Class Cephalopoda Cuvier, 1797

Subclass Ammonoidea Zittel, 1884

Order Agoniatitida Ruzhencev, 1957

Suborder Agoniatitina Ruzhencev, 1957

Superfamily Mimoceratoidea Steinmann, 1890

Family Mimosphinctidae Erben, 1953

Subfamily Anetoceratinae Ruzhencev, 1957

\section{Genus Anetoceras Schindewolf, 1934}

Type species. - "Cyrtoceratites arduennensis" Steininger, 1853 from the early Emsian of the Eifel in Germany (Stadtfeld Formation) designated by Schindewolf (1934).

Diagnosis. - See De Baets et al. (2009).

Discussion. - The genus Anetoceras has been recently revised by De Baets et al. (2009) and we refer to this article for definition of the genus and included species. To summarise, it now includes the type species Anetoceras arduennense and similar coarsely ribbed, gyroconically coiled Anetoceratinae, previously mostly included in Ruanites Yatskov, 1990.

\section{Anetoceras obliquecostatum Ruan \& He, 1974 Figure 16A}

1974 Anetoceras obliquecostatum sp. nov.; Ruan \& He, p. 238 , pl. 119, fig. 12 .

Figure 16. Lower Emsian ammonoids from the Dra Valley and the Tafilalt. • A - Anetoceras obliquecostatum Ruan \& He, 1974; lateral view, internal mould of phragmocone and body chamber; PIMUZ 28430. B, D - Anetoceras cf. obliquecostatum Ruan \& He, 1974. B - lateral view of whorl fragment, internal mould; PIMUZ 28431. D - lateral view of whorl fragment, internal mould; PIMUZ 28432. • C, E-I - Lenzites gesinae Klug, 2001. C - lateral view, cast of specimen with embryonic conch; PIMUZ 28433. E - lateral view, isolated body chamber; PIMUZ 28434. F - lateral view, isolated body chamber; PIMUZ 28435. G - lateral view, internal mould of phragmocone and body chamber, note the fine ribbing on the inner whorls; PIMUZ 28436. $\mathrm{H}$ - body chamber and counter part of phragmocone; PIMUZ 28437. I - lateral view, body chamber and counter part of the phragmocone up to the level of the protoconch; PIMUZ 28438. • A, C, F, G, I - Ouidane Chebbi; Lower Emsian; Erbenoceras Beds (Unit D of Klug 2001). • B, D, E, H - Dra Valley, Mdâour-El-Kbîr; Lower Emsian; Mdâour-El-Kbîr Formation (ammonoid-bearing level of the lower member sensu Hollard 1978). All figures natural size, except $\mathrm{C}(\times 3)$ and $\mathrm{I}(\times 2)$. All specimens whitened with ammonium chloride, except $\mathrm{C}$. 
Kenneth De Baets et al. • Zlíchovian faunas with early ammonoids, Anti-Atlas

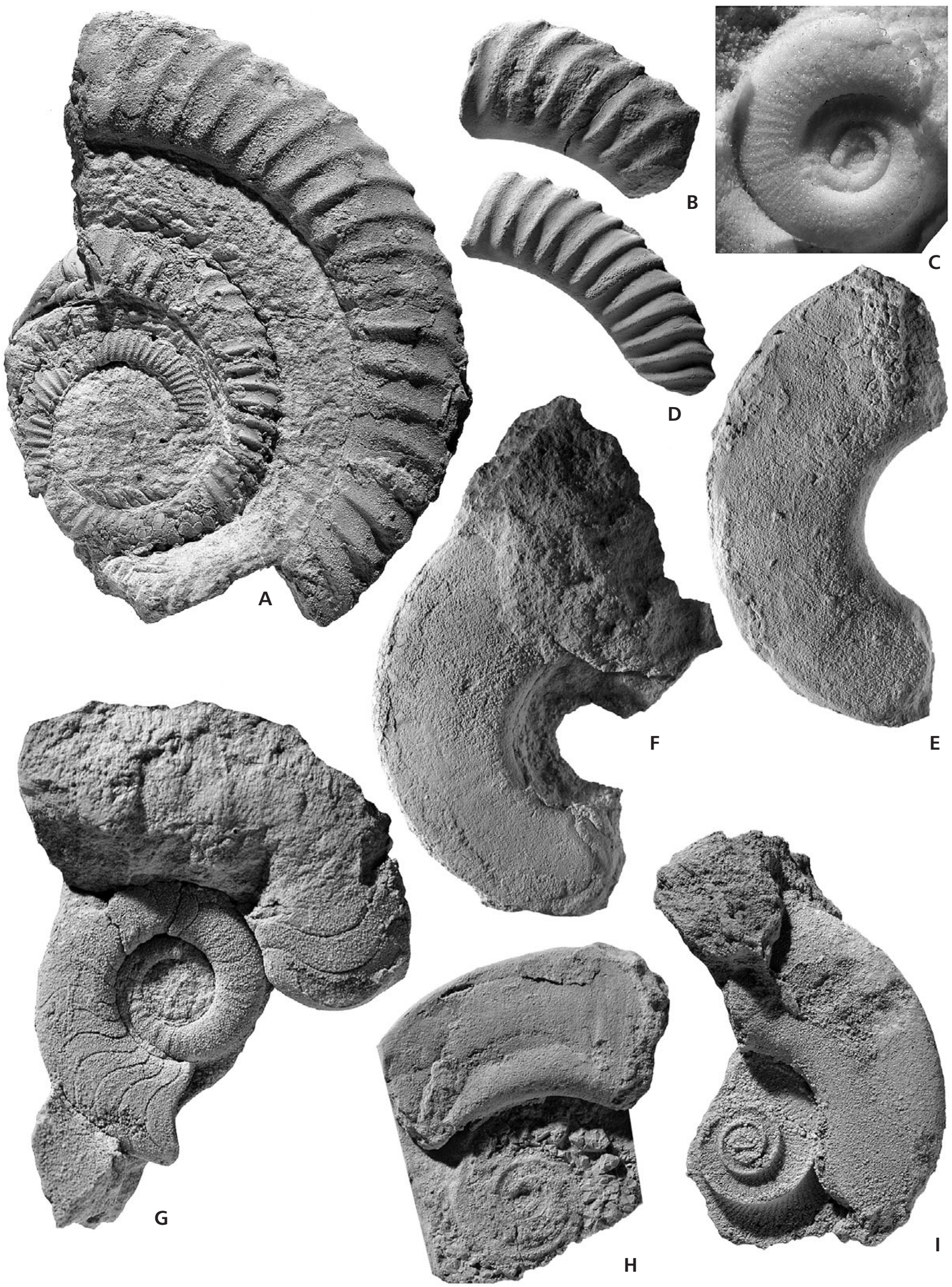


1975 Anetoceras recticostatum Erben. - Shen, pp. 92, 93, figs 3, 5-6, pl. 1, figs 11, 12.

1981 Anetoceras obliquecostatum Ruan \& He. - Ruan, p. 19, pl. 1, figs 2-4, 10, 13, 14, 16.

1988 Anetoceras obliquecostatum Ruan \& He. - Ruan, pl. 1, fig. 18.

1996 Ruanites obliquecostatus Ruan \& He. - Ruan, pl. 14.1, figs $1,7$.

2001 Anetoceras obliquecostatum Ruan \& He. - Klug, pp. 29, 30, fig. 8 , figs 2,8 .

Diagnosis. - See Klug (2001).

Description. - Specimen (PIMUZ 28430) has a very thinly discoidal conch ( $w w / d m=0.15$ at $\mathrm{dm}=70 \mathrm{~mm}$ ). Relative distance between subsequent whorls remains constant in middle growth stages, from 40 to $90 \mathrm{~mm}$, and in later growth stages, the distance between subsequent whorls slightly increases. The whorl interspace index (wi/wh) increases from about 0.2 at a diameter of $45 \mathrm{~mm}$ to 0.6 at diameter of $120 \mathrm{~mm}$. Its umbilicus is very wide (uw/dm $=0.64-0.69$ ), the whorl expansion rate decreases during ontogeny from 1.8 to 1.6.

The rib spacing increases from the early (RRI: 7) to the middle whorls (RRI: 5), but augments again in the last whorl (RRI: 6).

\section{Dimensions. -}

$\begin{array}{rccccccccc}\text { PIMUZ } & \text { dm } & \text { wh } & \text { wh/dm } & \text { uw } & \text { uw/dm } & \text { WER RRI } & \text { ARI } \\ 28430 & \sim 122 & 24.9 & 0.20 & \sim 82 & 0.67 & 1.6 & 6 & 5 \\ \sim 102 & 20.29 & 0.20 & \sim 68 & 0.66 & 1.6 & 6 & 6 \\ 57.31 & 12.89 & 0.22 & 37.07 & 0.65 & 1.7 & 5 & \\ 46.61 & 10.86 & 0.23 & 30.06 & 0.64 & 1.7 & 5 & 11 \\ 33.18 & 8.25 & 0.25 & 22.89 & 0.69 & 1.8 & 6 & 14 \\ & 5.71 & & & & & 6 & 24 \\ & 4.49 & & & & & 7 & \end{array}$

Remarks. - The figured specimen is just one example from a total of 15 Anetoceras specimens, which were collected recently from units C and D (sensu Klug 2001). They show relatively large variation in ribbing and coiling. This particular specimen derives from a loose block of Unit D, where it was associated with Erbenoceras advolvens and Lenzites gesinae. PIMUZ 28430 is the most similar to A. obliquecostatum Ruan, 1981 and is more openly coiled than the type species A. arduennense (Steininger, 1853). A. serpentinus and A. luofense have lower whorl expansion rates.

Occurrence. - Anetoceras obliquecostatum has so far been reported only from the early Emsian of China (Guangxi) and Morocco (eastern Anti-Atlas).

\section{Anetoceras cf. obliquecostatus Ruan \& He, 1974 Figure 16B, D}
cf. 1974 Anetoceras obliquecostatum Ruan \& He; Ruan \& He, p. 238, pl. 119, fig. 12 .

Material. - Two fragments preserved as internal moulds from the Mdâour-El-Kbîr (PIMUZ 28431-28432).

Description. - Their cross section is laterally compressed (ww/wh $=0.65-0.7$ ) with flanks converging towards the venter. The low curvature of both fragments suggests a loosely coiled, gyronic conch. Both fragments have rather densely spaced, coarse, rursiradiate ribs (ARI: 6-9, RRI: 6). The course of the growth lines is unknown because both fragments are preserved as internal moulds. The ribs are bent backwards and thin out dorsally. The suture line or septum shape is not visible in these fragments.

\begin{tabular}{llrrrr}
\multicolumn{2}{l}{ Dimensions. -} & \multicolumn{1}{c}{ ww } & ww/wh & RRI & ARI \\
PIMUZ & wh & \multicolumn{1}{l}{ (14.05 } & 0.7 & 6 & 6 \\
28431 & 20.91 & 10.8 & 0.7 & 6 & 8 \\
28432 & 15.92 & 9.95 & 0.7 & 6 & 9
\end{tabular}

Remarks. - The fragments are best assigned to Anetoceras, in particular Anetoceras obliquecostatum, the type species of Ruanites Yatskov, 1990, now synonimized with specimens figured by Ruan (1981) and Klug (2001). Fragments of Erbenoceras would be less curved, have a higher whorl height expansion rate and would be more or less advolute at this stage. Additionally, the ribbing in Anetoceras is typically more densely spaced in comparison with Erbenoceras. Other genera of the Anetoceratinae (Metabactrites, Borivites, Ivoites) are more loosely coiled than Anetoceras and have finer, often more densely spaced ribbing. The fragments resemble a specimen of Anetoceras obliquecostatum collected from Ouidane Chebbi (Fig. 16A).

Family Mimoceratidae Steinmann, 1890

\section{Genus Lenzites Becker \& House, 1994}

Type species. - Teicherticeras lenzi House, 1963 (in House \& Pedder, 1963) from the early Emsian (?dehiscens conodont Zone) of the Yukon (?Michelle Formation) in the Northwestern Territories of Canada designated by Becker \& House (1994, p. 102).

Diagnosis. - See Klug (2001).

Occurrence. - The type species was reported from the early Emsian of northern Canada and Novaya Zemlya 
(House \& Pedder 1963, Yatskov 1994). The genus has also been found in Morocco (see below). In both Novaya Zemlya and Morocco, the genus is associated with Erbenoceras (Yatskov 1994, Klug 2001).

\section{Lenzites gesinae Klug, 2001 emend.} Figure 16C, E-I

1999 Lenzites lenzi (House \& Pedder, 1963). - Belka et al., p. 14 , pl. 4 , fig. 4 , tab. 4.

2001 Lenzites gesinae sp. nov.; Klug, p. 43, figs 11.8, 11.11, 15, tab. 7.

2002 Lenzites gesinae Klug. - Korn \& Klug 2002, p. 63, figs $63 \mathrm{H}, 64 \mathrm{C}$.

Material. - Several calcareous specimens (over 10 specimens; only 4 are figured here) were collected from the $\mathrm{Er}$ benoceras Beds at Ouidane Chebbi. They are typically found together with Erbenoceras and, to a lesser extent, Anetoceras in Unit D. Two internal mould fragments from Mdâour-El-Kbîr (PIMUZ 28434, 28437) and three internal mould fragments (PIMUZ 28435, 28436, 28438) from Ouidane Chebbi. We made a cast (Fig. 16C) from one additional negative from the inner whorls of another specimen (PIMUZ 28433).

Diagnosis. - Lenzites with a very small imprint zone. Whorl cross section oval to subtrapezoidal (except for the first whorl which is subcircular). Moderately wide to wide umbilicus (uw/dm $=0.33$ to 0.56 ). Moderately high whorl expansion rate in early whorls (2.2-2.4) to high whorl expansion rate (2.4-3.0) in later whorls. Moderately large umbilical window (1.75-2 $\mathrm{mm}$ on $2.25-2.5 \mathrm{~mm})$. Inner whorls are ribbed up to diameters of $20 \mathrm{~mm}$. The ventral sinus of the growth lines is shallow and crescent-shaped. The suture line consists of a small, slender external lobe, a broadly rounded asymmetrical lobe, an asymmetrical ventrolateral saddle and a small internal lobe. The septum is moderately dorsoventrally bent and displays very subtle lateral inflections at a diameter of $70 \mathrm{~mm}$.

Description. - Preadult whorls were poorly known when the genus was introduced, but recently we have found at least two specimens, which are preserved up to the protoconch (latex cast of specimen PIMUZ 28434 and negative of specimen PIMUZ 28438). They display the ovoid protoconch shape and a moderately large umbilical window (1.75 on $2.25 \mathrm{~mm}$ in specimen PIMUZ 28434 and 2 on $2.5 \mathrm{~mm}$ in specimen PIMUZ 28438). The whorl section is initially subcircular to oval. It becomes subtrapezoidal at a diameter of about $50 \mathrm{~mm}$. The flanks are initially slightly vaulted, but later become flattened. The conch can reach a considerable size, with maximum diameters up to almost
$100 \mathrm{~mm}$. The largest, more or less complete specimens show at least 4 whorls.

The inner whorls of the internal mould possess coarse, rectiradiate ribs up to a diameter of about $10 \mathrm{~mm}$, but in some specimens, fainter ribbing can persist up to a diameter of $20 \mathrm{~mm}$.

The suture line of PIMUZ 28436 is identical to the one described by Klug (2001) and shows a shallow V-shaped internal lobe, an almost symmetrical lobe, which spans the flanks, an asymmetrical ventrolateral saddle and a moderately deep and narrow external lobe.

\section{Dimensions. -}

$\begin{array}{lcccccccc}\text { PIMUZ } & \text { dm } & \text { wh } & \text { wh/dm } & \text { ww } & \text { ww/dm } & \text { uw } & \text { uw/dm } & \text { WER } \\ 28436 & 35.5 & 13.6 & 0.38 & & & 14.1 & 0.40 & 2.6 \\ & 25.3 & 8.9 & 0.35 & 5.6 & 0.63 & 11.1 & 0.44 & 2.4 \\ 19.6 & 6.75 & 0.34 & & & 8.9 & 0.45 & 2.3 \\ 17.9 & 5.95 & 0.33 & & 8.3 & 0.46 & 2.2 \\ 15 & 5.15 & 0.34 & & 6.9 & 0.46 & 2.3 \\ 12.7 & 4.35 & 0.34 & & 6.55 & 0.52 & 2.3 \\ & 11.35 & 3.75 & 0.33 & & & 6.35 & 0.56 & 2.2 \\ 28433 & 37.8 & 15.70 & & & & & & 2.9\end{array}$

Remarks. - Lenzites gesinae has a higher whorl expansion rate, taller whorls and a smaller umbilicus than L. lenzi. The species is relatively common in some of Klug's (2001) Unit D beds across much of the Anti-Atlas, where it is often associated with Anetoceras obliquecostatum, Erbenoceras advolvens and E. solitarium (Klug 2001; new observations). The fragments from the basal member of the Mdâour-El-Kbîr Formation correspond well in whorl expansion rate, coiling and whorl section with the specimens from Ouidane Chebbi. They differ from Teicherticeras in their more angular ventrolateral edges. Chebbites has a lower whorl expansion rate and is more heavily ornamented. Conch parameters agree best with forms figured by Klug (2001) as Lenzites gesinae from Morocco. Coarser ornamentation as in Chebbites can be excluded.

Occurrence. - Lenzites gesinae is known from a rather restricted interval (Unit D of Klug 2001) and typically appears in the Erbenoceras Beds together with E. advolvens and Anetoceras obliquecostatum. The new specimens derive from a loose block of unit D containing Erbenoceras, found about $100 \mathrm{~m}$ eastward from the new section at Ouidane Chebbi, where they have been slightly dolomitised. The taxon has so far only been reported from the Anti-Atlas of Morocco. 
Family Teicherticeratidae Bogoslovsky, 1969

Subfamily Teicherticeratidae Bogoslovsky, 1969

\section{Genus Teicherticeras Erben, 1960}

Type species. - “Gyroceratites desideratus” Teichert, 1948 (= Teicherticeras teicherti Chlupáč \& Turek, 1983) from the early Emsian (perbonus conodont Zone) of Victoria in Australia (Travale Formation).

Diagnosis. - See Klug (2001).

Discussion. - Forms traditionally described as Teicherticeras comprise a rather heterogenous group of early Emsian ammonoids with respect to both shell form and ornamentation (from strong ribs to no distinct ribs at all). The status of Teicherticeras and Convoluticeras, considered a subgenus of Teicherticeras by some (Bogoslovsky 1963, 1969), has often been debated (House 1962, Bogoslovsky 1969, Chlupáč \& Turek 1983, Klug 2001 and Nikolaeva 2007). The problem lies in the definition of Convoluticeras and particularly in the definition of its type species C. lardeuxi, which is based on a juvenile shell (see discussions in Chlupáč \& Turek 1983, Klug 2001 and Nikolaeva 2007). We follow the concept proposed by Klug (2001) here. Despite these discrepancies $T$. senior, with its fine ribbing and whorl expansion rate, has been included in Teicherticeras by all authors (Becker \& House 1994, Klug 2001, Korn \& Klug 2002 and Nikolaeva 2007) since its erection by Chlupáč \& Turek (1983).

\section{Teicherticeras cf. senior Chlupáč \& Turek, 1983} Figure 17C

cf. 1983 Teicherticeras senior sp. nov.; Chlupáč \& Turek, pp. 29, 30, pl. 2, figs 1-4.

cf. 1994 Teicherticeras aff. senior Chlupáč \& Turek. - Becker \& House 1994, pl. 1, figs 12-16.
Material. - One calcareous specimen from Unit C of the Erbenoceras Beds at Ouidane Chebbi East (PIMUZ 28442). Internal mould with parts of at least two whorls preserved. Parts of the body chamber and phragmocone are also preserved.

Description. - The umbilical width ratio is moderately wide, from about 0.45 at a diameter of $80 \mathrm{~mm}$ to 0.4 at a diameter of $30 \mathrm{~mm}$. The whorls are touching (advolute), but no whorl overlap can be distinguished. The whorl expansion rate is very high (approximately 3.3 at a diameter of $80 \mathrm{~mm}$ ) in the outer whorl to high in the inner whorl (about 2.8 at a diameter $30 \mathrm{~mm}$ ). The conch is discoidal with a reconstructed ww/dm ratio of about 0.4 . The body chamber completes minimally about 110 degrees or 0.31 whorls. The size of the umbilical perforation or the ammonitella is not known. The whorl section of the last whorl is subtrapezoidal with the flanks converging towards the venter and the cross section of the inner whorls is more or less oval.

The ornamentation consists of ribs and growth lines which are largely parallel with the ribs. The ribs become more densely spaced and more rursirate throughout ontogeny; they are bent back on the venter and less closely spaced on the inner whorl $\left(\mathrm{ARI}_{20} \sim 10\right.$ at a diameter of $40 \mathrm{~mm}$ ) than on the outer whorl $\left(\mathrm{ARI}_{20} \sim 13\right.$ at a diameter of $80 \mathrm{~mm})$.

The specimen is heavely worn, so the exact course of the suture line cannot be determined. Only a broad lateral lobe is discernable.

Discussion. - It is the first time that Teicherticeras has been reported from the Tafilalt and our specimen is also the first in situ specimen so far in Morocco. The specimen is rather weathered in some places, resulting in the appearance that it is not advolute in some parts of the outer whorl. However, the touching whorls before and after the large interspace prove otherwise. At diameters between

Figure 17. Cephalopods from the Dra Valley and the Tafilalt. • A, B, H-K - Spyroceras fukujiense Niko, 1996. A - lateral view, body chamber and phragmocone, shell preserved, × 1; PIMUZ 28439; Jebel Mech Irdane; Erbenoceras Beds. B, I - lateral view of the body chamber and phragmocone plus enlarged lateral view of the phragmocone, $\times 1$ and $\times 2$; PIMUZ 28440; Ouidane Chebbi, Erbenoceras Beds. J, K - lateral views, phragmocone, shell preserved, × 2; PIMUZ 28441; Mdâour-El-Kbîr; Mdâour-El-Kbîr Formation (level with ammonoids). • C, D -Teicherticeras cf. senior Chlupáč \& Turek, 1983; lateral and ventral views, internal mould of body chamber and part of phragmocone, $\times 1$; PIMUZ 28442; Ouidane Chebbi; Erbenoceras Beds (Unit C of Klug 2001). • E, F - Cyrtobactrites scheffoldi Klug et al., 2008; septal and lateral views, internal mould of phragmocone, $\times 3$; PIMUZ 28443; Achguig East; Unit B of Klug 2001 (Faunule 2). $\bullet$ G, H - Oncoceratidae gen. et sp. indet., dorsal and ventral views, internal mould of phragmocone, $\times 3$; PIMUZ 28444; Hassi Tachbit, Unit B3 of Bultynck \& Walliser 2000a, b (Faunule 1). • M, L - Devonobactrites sp., ventral and lateral view, internal mould of the body chamber, × 5; PIMUZ 28445; Mdâour-El-Kbîr; Merzâ-Akhsaï Formation (Faunule 1). • N, O - Orthocycloceras sp.; ventral and lateral views, internal mould of body chamber, × 1; PIMUZ 28446; Mdâour-El-Kbîr; Mdâour-El-Kbîr (level with ammonoids). • P, Q - Orthocycloceras tafilaltense Kröger, 2008. P - lateral view, internal mould of body chamber with parts of the shell, $\times 2$; PIMUZ 28447; Takkat Ou El Heyene; Unit B3 of Bultynck \& Walliser 2000a, b (Faunule 1). Q - lateral view, internal mould of body chamber with parts of the shell, $\times 2$; PIMUZ 28448; Achguig East, Unit B of Klug 2001 (Faunule 2) or Erbenoceras Beds. • R-U - Devonobactrites obliqueseptatus (Sandberger \& Sandberger, 1852). R, S - lateral and septal views, internal mould of body chamber, × 3; PIMUZ 28451; Mdâour-El-Kbîr; Merzâ-Akhsaï Formation (Faunule 1). T, U - lateral and lateroventral views, internal mould of body chamber, $\times$ 3; PIMUZ 28452; Hassi Tachbit, Unit B3 of Bultynck \& Walliser 2000a, b (Faunule 1). All specimens whitened with ammonium chloride. 
Kenneth De Baets et al. • Zlíchovian faunas with early ammonoids, Anti-Atlas

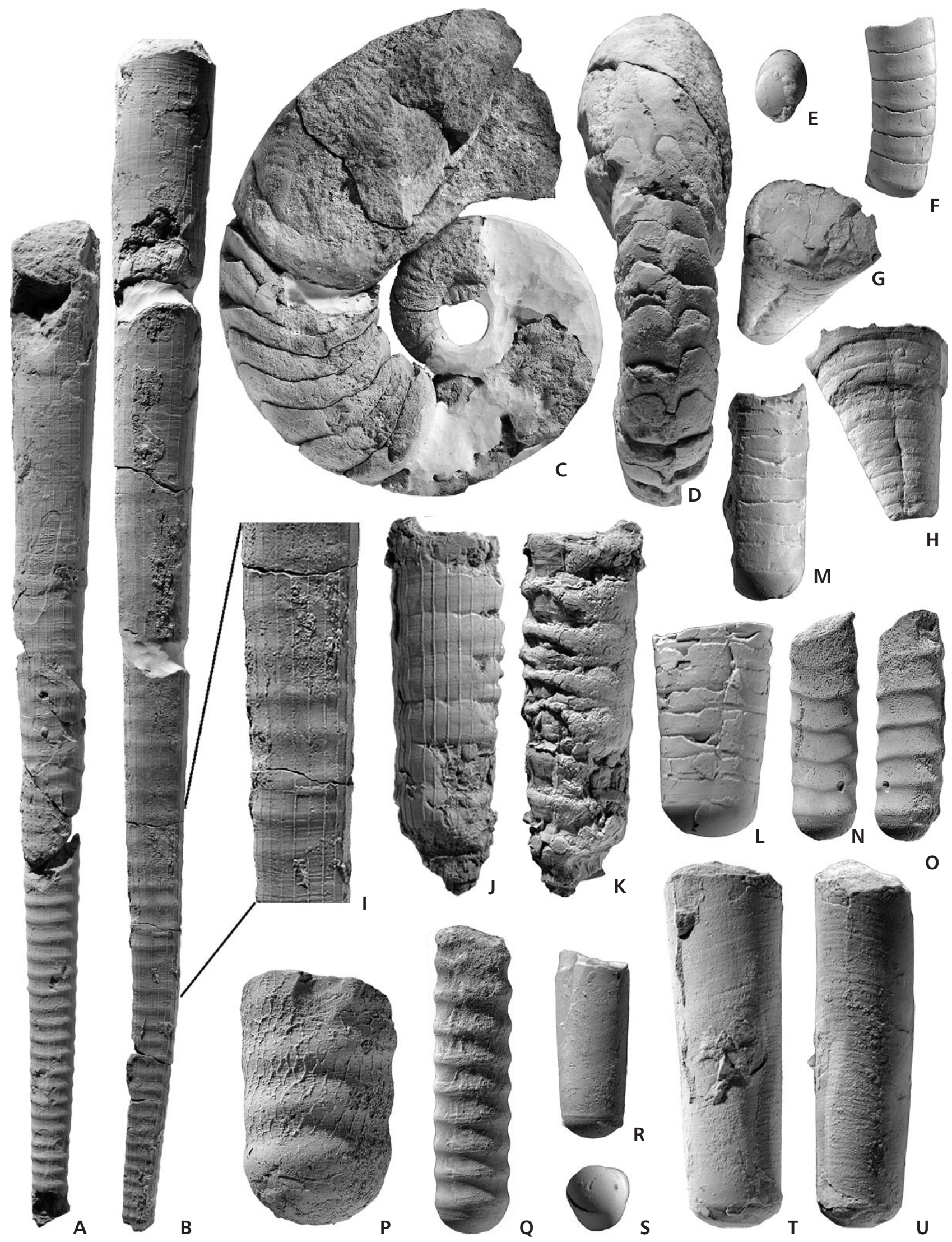




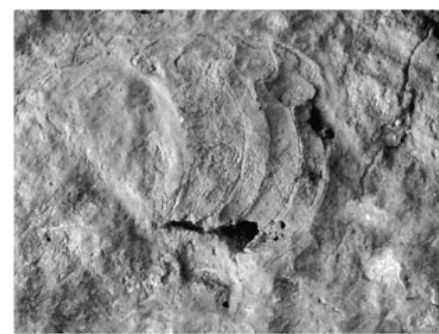

\section{$A$}
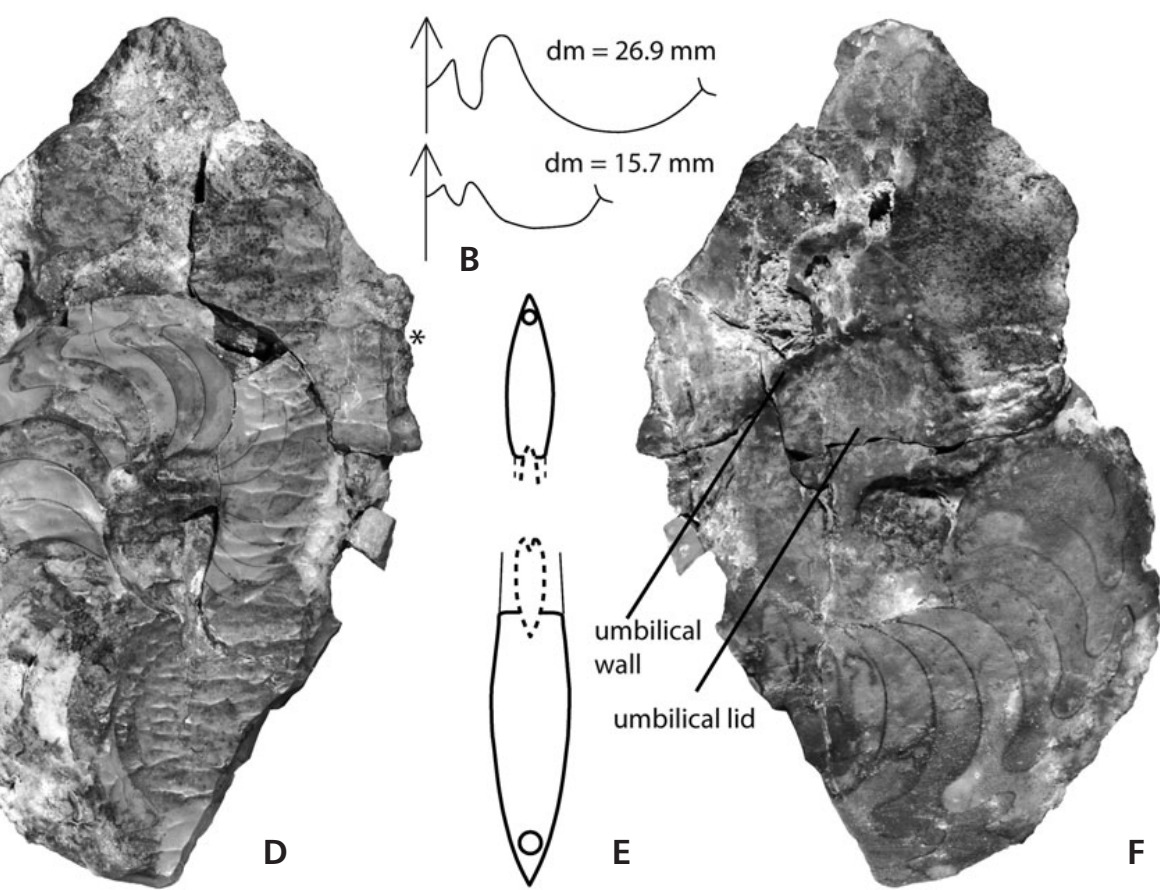

Figure 18. Weyeroceras angustus Klug, 2001. - A - whorl fragment photographed on a loose block from Unit D (Erbenoceras Beds), where it was directly associated with Erbenoceras, about $100 \mathrm{~m}$ westward from our section. • B-F-internal mould with parts of the shell (umbilical lid); PIMUZ 28449; Bou Tchrafine; Erbenoceras Beds (Unit D or E). • B - suture line at whorl height of $26.9 \mathrm{~mm}$ and $15.7 \mathrm{~mm}$, up to the umbilical wall. $\bullet \mathrm{C}-\mathrm{sketch}$ of the specimen using data from the left and right sides of the specimen. The striped line shows the edge of the previous whorl and the dotted line shows the estimated whorl height of the last demi-whorl. $\bullet \mathrm{D}$ - right side, partially weathered in the plane of symmetry. $\bullet \mathrm{E}-\mathrm{drawing}$ of the whorl section, note the subventral position of the siphuncle. $\bullet \mathrm{F}$ - left side, note the presence of an umbilical lid below the umbilical wall. All figures natural size $(\times 1)$, except $\mathrm{C}$ (× 0.5). Specimen PIMUZ 28449 was found by M. Wasmer (Zürich).

30 and $80 \mathrm{~mm}$ our specimen has a broader whorl cross-section $(\mathrm{ww} / \mathrm{wh}=0.8)$ and more rounded flanks than Chebbites (ww/wh $=0.5$ to 0.6$)$ and Lenzites $(\mathrm{ww} / \mathrm{wh}$ $=0.2$ to 0.3$)$.

The ornamentation and coiling is very similar to Teicherticeras senior. The specimens from Bohemia were found compressed in shale, so the whorl section is not known exactly. Becker \& House (1994) reported a loosely collected specimen as Teicherticeras aff. senior from Bou Dîb in the Maïder. The ribbing of our specimen is closer to that of the Barrandian specimens than to that figured by Becker \& House (1994) from the Maïder which is more densely ribbed on the middle whorls. The specimens from the Barrandian co-occur with Anetoceras oriens and were found below beds with Nowakia cf. praecursor (Chlupáč \& Turek 1983). In the same interval, Anetoceras has also been found. Alberti (1981) reported Nowakia cf. praecursor from these correlative beds at Bou Tchrafine in the Tafilalt. Similar forms (?Teicherticeras nantanense) might also be present in the praecursor Zone of Guangxi (Ruan 1981, 1996), where they are associated with Anetoceras, although their poor preservation does not allow further comparison with our specimen or conclusions regarding their affinity with Teicherticeras senior.

\section{Genus Weyeroceras Klug, 2001}

Diagnosis. - See Klug (2001).

Distribution. - Anti-Atlas, Morocco and Cantabrian Mountains, Spain.

Weyeroceras angustus Klug, 2001 emend. Figure 18A-F

2001 Weyeroceras angustus sp. nov.; Klug 2001, pp. 58, 59, figs 20, 21.

Material. - Three calcareous internal moulds: two whorl fragments (the holotype GPIT 1849-2067 and GPIT 1849-2067) from Ouidane Chebbi and a more complete, new specimen PIMUZ 28449 (leg. M. Wasmer) from the Erbenoceras Beds of Bou Tchrafine close to the road $\left(31^{\circ} 23^{\prime} 9.12^{\prime \prime} \mathrm{N}\right.$; $4^{\circ} 10^{\prime} 16.59^{\prime \prime}$ ). An additional whorl fragment (see Fig. 18A) was found which could not be extracted from a block about $400 \mathrm{~m}$ to the $\mathrm{W}$ of our new section at Ouidane Chebbi.

Diagnosis. - Moderately large Weyeroceras (estimated maximum diameter: $110 \mathrm{~mm}$ ) with a narrow umbilicus 
(uw/dm $=0.23-0.30)$ and high to very high WER (2.9-3.6). Very thinly discoidal conch ( $w$ w/wh = $0.24-0.30$ ) with a distinct imprint zone, but only weakly embracing whorls (IZR: 0.07-0.11). Umbilicus covered by a broad umbilical lid. Suture line with a small external lobe, a small, flat adjacent saddle, a moderately large parabolic ventrolateral lobe, a slightly larger saddle of similar shape followed by a rounded lateral lobe. Subventral siphuncle.

Description. - The embryonic conch and early whorls are not preserved in the more complete specimen PIMUZ 28449. The shell of PIMUZ 28449 is oxyconic and thinly discoidal $(0.24$ to 0.29 between $19 \mathrm{~mm}$ and $106 \mathrm{~mm}$ ). The whorls of PIMUZ 28449 have a distinct imprint zone with only weakly embracing whorls (IZR = 0.08 at a whorl height of about $16 \mathrm{~mm}$ to 0.11 at an estimated whorl height of $106 \mathrm{~mm})$. The conch is oxyconic at least in the penultimate (PIMUZ 28449) and last whorl (holotype GPIT 1849-2067). The whorl expansion rate decreases from about 3.4 at a diameter of $19 \mathrm{~mm}$ to 3.1 at a diameter between $59 \mathrm{~mm}$ and $\mathrm{ca} 106 \mathrm{~mm}$. The relative size of the umbilicus augments from an uw/dm-ratio of 0.23 at a diameter $35 \mathrm{~mm}$ to 0.26 at a diameter of $59 \mathrm{~mm}$ and 0.28 at an estimated diameter of $106 \mathrm{~mm}$. The other specimens are poorly preserved, but also indicate an oxyconic conch. Ribs are absent and the growth lines are not preserved. The umbilicus in PIMUZ 28449 is covered by outgrowths of the lateral shell wall (see Fig. 18F).

Specimen PIMUZ 28449 has a suture line with a small external lobe, a small adjacent saddle, a moderately large parabolic lobe, a slightly larger saddle of similar shape followed by a rounded lateral lobe from a whorl height of 14 to $27 \mathrm{~mm}$. The lateral lobe changes from a more triangular shape in earlier ontogeny to a more parabolic shape in later ontogeny (Fig. 18B). The siphuncle is subventral (Fig. 18D) and its position corresponds with the position of the lobe in ventrolateral position. All other examined specimens (including the holotype and the one we had to leave in the field) show roughly the same elements and characters in the suture, but the precise course of the suture line near the umbilical (e.g. external lobe) is not known due to corrosion and poor preservation. The course of the suture line within the imprint zone is still unknown.

\section{Dimensions. -}

PIMUZ dm wh wh/dm uw uw/dm ww ww/wh WER IZR $\begin{array}{llllllllll}28449 & \sim 106 & \sim 50 & 0.47 & 29.28 & 0.28 & \sim 15 & 0.30 & 3.0 & 0.07\end{array}$ $\begin{array}{lllllllll}59.02 & 27.34 & 0.46 & 15.38 & 0.26 & 7.44 & 0.27 & 3.1 & 0.07\end{array}$ $\begin{array}{lllllllll}34.57 & 16.34 & 0.47 & 7.94 & 0.23 & 4.26 & 0.26 & 3.1 & 0.08\end{array}$
Remarks. - So far, only four specimens (including the specimen in Fig. 17A, which is still in situ) have been found in 11 years of fieldwork in this area. The specimen we found about $350 \mathrm{~m}$ to the SW of our new section (Fig. 17A) is poorly preserved and does not append any new information to the description. It was found in a loose block together with Erbenoceras, but the lithology of the block and the co-occurrence with Erbenoceras point to a stratigraphic position in Klug's (2001) Unit D.

This is corroborated by the fact that at this place, Unit E was not preserved due to erosion. It extends the stratigraphic range of the taxon to a slightly lower stratigraphic position (Unit D) as opposed to the two specimens reported by Klug (2001) from Unit E. The previous stratigraphic interpretation given by Klug (2001) was most likely based on a misinterpretation of the local stratigraphic situation, where the limestones of Unit E were actually eroded and Unit D formed the topmost layer of the Early Emsian ridge.

Weyeroceras angustus is distinguished from other Auguritidae by its rather wide umbilicus and its characteristic suture line (Fig. 17B) with one saddle and one lobe less in the ventrolateral position than Celaeceras and one small lobe less than in Gaurites. A form with similar coiling and an identical suture line was reported in open nomenclature from the Cantabrian Mountains as "Celaeceras sp." (Montesinos \& García-Alcalde 1996). The specimen from Spain was derived from the elegans Zone while our specimens probably are from the barrandei Zone and maybe also the elegans Zone (see Klug 2001).

The umbilicus is covered by extensions of the lateral shell (see Fig. 17F), the umbilical lid sensu Klug \& Korn (2002). This structure is similar to that in the not directly related pinacitids (Exopinacites and Pinacites; Klug 2002, Klug \& Korn 2002).

\section{Conclusions}

The limonitised faunules reported here are not only from the pelagic facies of the Tafilalt but also from the more pelagic lower part of the Rich El Ansar (Mdâour-El-Kbîr Formation) and the top of the Merzâ-Akhsaï Formation at Mdâour-El-Kbîr. In the Early Emsian of the Anti-Atlas, the facies differentiation is less intense than in younger parts of the Devonian of Morocco (compare Kaufmann 1998, Lubeseder et al. 2009), which might partially explain why these faunules are so similarly composed and occur in a similar facies over a linear distance of $350 \mathrm{~km}$. The faunas proved useful in correlating the Zlíchovian (early Emsian) of the Anti-Atlas from the eastern Tafilalt to the Dra Valley, but with additional biostratigraphic information, the resolution of the correlation can still be 
enhanced. More precise studies combing data on multiple groups are urgently needed, most notably ammonoids, conodonts and dacryoconarids. The lower faunule at Mdâour-El-Kbîr is very similar to Faunule 1 from the Tafilalt, which could suggest a correlation of the upper part of the Merzâ-Akhsaï Formation in the Dra Valley and the marls intercalated between the Pragian Limestone and Deiroceras Limestone in the Ouidane Chebbi region and the rest of the Tafilalt. The similarity of the upper faunule and ammonoid finds corroborate the correlation of parts of the lower Mdâour-El-Kbîr Formation (lower member of Hollard 1978) with the Erbenoceras Beds and the claystones/marls below it. The co-occurrence of coarsely ribbed Anetoceratinae with Lenzites both being found in the Tafilalt (Ouidane Chebbi) and Dra Valley (Mdâour-El-Kbîr) enabled correlation of the middle part of the lower member of the Mdâour-El-Kbîr Formation (level with ammonoids) with Unit D of Klug (2001) from the Erbenoceras Beds.

\section{Acknowledgements}

This study is a contribution to the Swiss National Science Foundation Project No. 113956 (CK and KDB). Pierre Bultynck (Brussels) kindly provided an image and a sketch of his Mdâour-El-Kbîr section. Working permits were provided by colleagues of the Ministčre de l'Energie et des Mines (Rabat). Markus Hebeisen, Martin Wasmer and Christian Kolb (all from the Paläontologisches Institut und Museum, Zürich) assisted with some of the fieldwork in Morocco (2008-2009). Jiří Frýda (Czech Geological Survey, Prague) checked our gastropod determinations. Björn Kröger (Museum für Naturkunde, Berlin) and Jiří Kříž (Czech Geological Survey, Prague) helped with determination of some of the bactritoids/nautiloids and some of the bivalves respectively. Rosi Roth (Zürich) made casts of some of the ammonoids, corals and gastropods. Mikołaj Zapalski (Institute of Paleobiology, Warszawa) kindly discussed our coral determinations for an earlier draft of this manuscript and made some thin sections. We appreciate the assistance of James Neenan and Laura Wilson (Paläontologisches Institut und Museum, Universität Zürich) for assistance with our English. We acknowledge the comments/corrections by the handling editor and the reviews by Volker Ebbighausen (Odenthal) and Vojtěch Turek (National Museum, Department Paleontology, Prague), which significantly improved the manuscript.

\section{References}

AlBERTI, G.K.B. 1980. Neue Daten zur Grenze Unter-/ MittelDevon, vornehmlich aufgrund der Tentaculiten und Trilobiten im Tafilalt (Marokko). Neues Jahrbuch für Geologie und Paläontologie, Monatshefte 1980, 581-594.

ALBERTI, G.K.B. 1981. Daten zur stratigraphischen Verbreitung der Nowakiidae (Dacryoconarida) im Devon von NW-Afrika
(Marokko, Algerien). Senckenbergiana lethaea 62(2), 205-216.

BARRANDE, J. 1865. Système silurien du centre de la Bohême, I. Partie, Vol. II : Céphalopodes. Pl. 1-107. Prague \& Paris.

BECKER, G., LAZREQ, N. \& WedDIGE, K. 2004a. Ostracods of Thuringian provenance from the Devonian of Morocco (Lower Emsian-middle Givetian; south-western Anti-Atlas). Palaeontographica, Abteilung A 271(1-4), 1-109.

BeCKER, T.R., ABOUSSAlAM, S.Z., BOCKWINKel, J., EBbiGHAUSEN, V., El HASSANI, A. \& NÜBEL, H. 2004b. Upper Emsian stratigraphy at Rich Tamelougou near Torkoz (SW Dra Valley, Morocco). Documents de l'Institut Scientifique Rabat 19, 85-89.

BECKER, R.T., ABOUSSALAM, Z.S. \& BRETT, C.E. 2008. Highresolution biostratigraphy of Emsian mixed siliciclastic-carbonate successions of the western Dra Valley (Anti-Atlas, SW Morocco), 14-18. In KIM, A.I., SAlimovA, F.A. \& MESHCHANKINA, N.A. (eds) International Conference "Alignments of Lower Devonian Carbonate and Clastic Sequences" (IGCP 499 Project/SDS joint field meeting), Contributions.

Becker, T.R., Bockwinkel, J., EbBighausen, V., AbousSALAM, S.Z., El HASSANI, A. \& NÜBEL, H. 2004c. Lower and Middle Devonian stratigraphy and faunas at Bou Tserfine near Assa (Dra Valley, SW Morocco). Documents de l'Institut Scientifique Rabat 19, 90-100.

BECKER, R.T. \& HOUSE, M.R. 1994. International Devonian goniatite zonation, Emsian to Givetian, with new records from Morocco. Courier Forschungsinstitut Senckenberg 169 [Willi Ziegler Festschrift II], 79-135.

BECKER, R.T. \& HousE, M.R. 2000. Emsian and Eifelian ammonoid succession at Bou Tchrafine (Tafilalt platform, Anti-Atlas, Morocco). In El HASSANI, A. \& TAHIRI, A. (eds) Moroccan meeting of the Subcommision on Devonian Stratigraphy (SDS) - IGCP 421 Excursion Guidebook, Notes et Mémoires du Service Géologique 399, 21-26.

BECKER, T.R., JANSEN, U., PlODOWSKI, G., SCHINDlER, E., ABoussalam, S.Z. \& WedDIGE, K. 2004d. Devonian lithoand biostratigraphy of the Dra Valley area - an overview. Documents de l'Institut Scientifique Rabat 19, 3-18.

BelKa, Z., Klug, C., KaufmanN, B., KoRn, D., DÖRING, S., FEIST, R. \& WENDT, J. 1999. Devonian conodont and ammonoid succession of the eastern Tafilalt (Ouidane Chebbi section), Anti-Atlas, Morocco. Acta Geologica Polonica 49(1), 1-23.

BogoslovsKy, B.I. 1969. Devonskie ammonoidei. I. Agoniatity. Trudy Paleontologicheskogo Instituta Akademiya Nauk SSSR 124, 1-341.

BogosLOVSKY, B.I. 1984. Novyy rod semeystva Auguritidae i soputstvuyushchie emu ammonoidei iz nizhnego Devona zeravshanskogo Khreta. Paleontologicheskiy Zhurnal 1984(1), 30-36.

Boumendjel, K., Brice, D., Copper, P., GOURVennec, R., Jahnke, H., LardeuX, H., Le Menn, J., Melou, M., Morzadec, P., Paris, F., Plusquellec, Y. \& RACheBOEUF, P. 1997. Les faunes de Dévonien de l'Ougarta (Sahara occidental, Algerie). Annales de la Société Géologique du Nord, $2^{\text {eme }}$ serie 5, 86-116. 
BultynCK, P. \& HOllaRd, H. 1980. Distribution comparée de Conodontes et Goniatites dévoniens des plaines du Dra, du Ma'der et du Tafilalt (Maroc). Aardkundige Mededelingen 1, 9-73.

BUltynck, P. \& WALliSER, O.H. 2000a. Emsian to Middle Frasnian sections in the northern Tafilalt. Notes et Mémoirs du Service géologique Maroc 399, 11-20.

BultynCK, P. \& WALliser, O.H. 2000b. Devonian Boundaries in the Moroccan Anti-Atlas. Courier Forschungsinstitut Senckenberg 225, 211-226.

CARLS, P. 1999. El Devónico de Celtiberia y sus Fósiles. Jornadas Aragonesas de Paleontología 6, 101-164.

CARlS, P., SLAVíK, L. \& VALENZUELA-Ríos, J.I. 2008. Comments on the GSSP for the basal Emsian stage boundary: the need for its redefinition. Bulletin of Geosciences 83(4), 383-390. DOI 10.3140/bull.geosci.2008.04.383

CHLUPÁČ, I. \& KUKAL, Z. 1988. Possible global events and the stratigraphy of the Barrandian Paleozoic (Cambrian - Devonian, Czechoslovakia). Sborník geologických věd, Geologie 43, 83-146.

ChLupÁČ, I. \& TUREK, V. 1983. Devonian goniatites from the Barrandian area. Rozpravy Ústředního ústavu geologického 46, 1-159.

CONRAD, T.A. 1841. Fifth annual report on the palaeontology of the State of New York. Annual Report of the Geological Survey of New York 5, 25-57.

CUVIER, G. 1797. Tableau élémentaire de l'histoire naturelle des animaux. 710 pp. Baudouin, Paris.

DE BAETS, K., Klug, C. \& KoRn, D. 2009. New Anetoceratinae (Ammonoidea, Early Devonian) from Germany with a revision of their genera. Neues Jahrbuch für Geologie und Paläontologie. Abhandlungen 252(3), 361-376. DOI 10.1127/0077-7749/2009/0252-0361

EbBighausen, V., BockWinkel, J., Becker, T.R., AbOUSSALAM, S.Z., BULTYNCK, P., El HASSANI, A. \& NÜBEL, H. 2004. Late Emsian and Eifelian stratigraphy at Oufrane (Tata region, eastern Dra Valley, Morocco). Documents de l'Institut Scientifique Rabat 19, 44-52.

EHRENBERG, C.G. 1834. Beiträge zur physiologischen Kenntniß der Corallenthiere im allgemeinen, und besonders des rothen Meeres, nebst einem Versuche zur physiologischen Systematik derselben. Abhandlungen der Köninglichen Akademie der Wissenschaften in Berlin 1832, 225-380.

ERBEN, H.K. 1953. Goniatitaceae (Cephalopoda) aus dem Unterdevon und dem Unteren Mitteldevon. Neues Jahrbuch für Geologie und Paläontologie, Abhandlungen 98, 175-225.

ERBEN, H.K. 1960. Primitive Ammonoidea aus dem Unterdevon Frankreichs und Deutschlands. Neues Jahrbuch für Geologie und Paläontologie, Abhandlungen 110(1), 1-128.

FRÝDA, J. \& MANDA, Š. 1997. A gastropod faunule from the Monograptus uniformis graptolite Biozone (Early Lochkovian, Early Devonian) in Bohemia. Mitteilungen aus dem Geologisch-Paläontologischen Institut der Universität Hamburg 80, 59-121.

FrÝdA, J., FERrovÁ, L., BERKYOVÁ, S. \& FrÝdOVÁ, B. 2008. A new Early Devonian palaeozygopleurid gastropod from the Prague Basin (Bohemia) with notes on the phylogeny of the
Loxonematoidea. Bulletin of Geosciences 83(1), 93-100. DOI 10.3140/bull.geosci.2008.01.093

GARCÍA-ALCALDE, J. 1997. North Gondwanian Emsian events. Episodes 20(4), 241-246.

GARCÍA-LOPEZ, S. \& SANZ-LÓPEZ, J. 2002. Devonian to Lower Carboniferous conodont biostratigraphy of the Bernesga Valley section (Cantabrian Zone, NW Spain). Cuadernos del Museo Geominera de España 1, 163-194.

GIRTY, G.H. 1910. The fauna of the Caney shale of Oklahoma. U.S. Geological Survey Bulletin 377, 1-106.

GolDFuss, G.A. 1840. Petrefacta Germaniae 7, 225-312. Arnz \& comp., Düsseldorf.

HALL, J. 1874. Descriptions of new species of Goniatitidae. With a list of previously described species. Annual Reports of the Regents of the University of the State New York, on the condition of the State Cabinet of Natural History, and the Historical and Antiquarian Collection annexed thereto 26, 1-4.

HollaRD, H. 1963a. Un tableau stratigraphique du Dévonien du Sud de l'Anti-Atlas. Notes et Mémoires du Service géologique 23, 105-107.

HOLLARD, H. 1963b. Les Acastella et quelques autres Dalmanitacea du Maroc présaharien. Leur distribution verticale et ses conséquences pour l'étude de la limite Silurien-Dévonien. Notes et Mémoires du Service géologique 176, 1-60.

HollaRD, H. 1963c. Présence d'Anetoceras advolvens Erben (Ammonoïdée primitive) dans le Dévonien inférieur du Maroc présaharien. Notes du Service de Mines et de la Carte géologique du Maroc 23, 131-138.

HOLLARD, H. 1965. Précisions sur la stratigraphie et la repartition de quelques espèces importantes du Silurien supérieur et de l'Éodévonien du Maroc présaharien. Notes et Mémoires du Service géologique 24(183), 23-32.

HollaRD, H. 1967. Le Devonien du Maroc et du Sahara NordOccidental, 203-244. In International Symposium on the Devonian System 2. Calgary.

HOLLARD, H. 1974. Recherches sur la stratigraphie des formations du Dévonien moyen, de l'Emsien supérieur au Frasnien, dans le Sud du Tafilalt et dans le Ma'der (Anti-Atlas oriental, Maroc). Notes du Service géologique du Maroc 36(264), $7-68$.

HollaRD, H. 1977. Le domaine de l'Anti-Atlas au Maroc, 168-194. In MARTINSSON, A. (ed.) The Silurian-Devonian boundary. Final report of the Committee on the Silurian-Devonian Boundary within IUGS Commission on Stratigraphy and a state of the art report for Project Ecostratigraphy. IUGS Series A 5.

HOLLARD, H. 1978. Corrélations entre niveaux à brachiopodes et à goniatites au voisinage de la limite Dévonien inférieur Dévonien moyen dans les plaines du Dra (Maroc présaharien). Newsletters on Stratigraphy 7(1), 8-25.

HollaRD, H. 1981a. Principaux caractères des formations dévoniennes de l'Anti-Atlas. Notes et Mémoires du Service Géologique du Maroc 42(308), 15-22.

Hollard, H. 1981b. Tableaux de corrélations du Silurien et du Dévonien de l'Anti-Atlas. Notes et Mémoires du Service Géologique du Maroc 42(308), 23. 
Hollard, H. \& JACQuemont, P. 1956. Le Gothlandien, le Dévonien et le Carbonifère des Régions du Dra et du Zmoul. Notes et Mémoires du Service géologique du Maroc 15(135), $7-33$.

HousE, M.R. 1962. Observations on the ammonoid succesion of the North American Devonian. Journal of Paleontology 36, 247-284.

House, M.R. \& PedDER, A.E.H. 1963. Devonian goniatites and stratigraphical correlations in Western Canada. Palaeontology $6,491-539$.

JAnsen, U. 2001. Morphologie, Taxonomie und Phylogenie unter-devonischer Brachiopoden aus der Dra-Ebene (Marokko, Präsahara) und dem Rheinischen Schiefergebirge (Deutschland). Abhandlungen der Senckenbergischen Naturforschenden Gesellschaft 55, 1-389.

JANSEN, U., PLODOWSKI, G., SCHEMM-GREGORY, M., SCHINDLER, E. \& WedDige, K. 2004. The Pragian at Assa (SW Dra Valley, Morocco). Documents de l'Institut Scientifique Rabat 19, 64-68.

JANSEN, U., LAZREQ, N., PlodOWSKI, G., SCHEMM-GREGORY, M., SCHINDLER, E. \& WedDIGE, K. 2007. Neritic-pelagic correlation in the Lower and basal Middle Devonian of the Dra Valley (Southern Anti-Atlas, Moroccan Pre-Sahara). In BECKER, R.T. \& KIRCHGASSER, W.T. (eds) Devonian Events and Correlations, Geological Society Special Publication 278, 9-37.

KAUFMANN, B. 1998. Facies, stratigraphy and diagenesis of Middle Devonian reef- and mud-mounds in the Mader (eastern Anti-Atlas, Morocco). Acta Geologica Polonica 48, 43-106.

KLUG, C. 2001. Early Emsian ammonoids from the eastern Anti-Atlas (Morocco) and their succession. Paläontologische Zeitschrift 74(4), 479-515.

KLUG, C. 2002. Quantitative stratigraphy and taxonomy of late Emsian and Eifelian ammonoids of the eastern Anti-Atlas (Morocco). Courier Forschungsinstitut Senckenberg 238, $1-109$.

KLUG, C. \& KoRN, D. 2002. Occluded umbilicus in the Pinacitinae (Devonian) and its palaeoecological implications. Palaeontology 45(5), 917-931. DOI 10.1111/1475-4983.00268

KLUG, C. 2007. Sublethal injuries in Early Devonian cephalopod shells from Morocco. Acta Palaeontologica Polonica 52(4), 749-759.

Klug, C., KröGer, B., RÜCKLIN, M., Korn, D., SCHEMMGREGORY, M., DE BAETS, K. \& MAPES, R.H. 2008. Ecological change during the early Emsian (Devonian) in the Tafilalt (Morocco), the origin of the Ammonoidea, and the first African pyrgocystid edrioasteroids, machaerids and phyllocarids. Palaeontographica A 283, 83-176.

Klug, C., Kröger, B., Kiessling, W., Mullins, G.L., SerVAIS, T., FRÝDA, J., KORN, D. \& TURNER, S. 2009. The Devonian nekton revolution. Lethaia. DO1 $10.1111 / \mathrm{j} .1502-3931.2009 .00206 . x$

KoCH, C. 1883a. Monographie der Homalonotus-Arten des rheinischen Unterdevon. Königlich Preussischen geologischen Landesanstalt. xxxi +85 pp. H. Neumann, Berlin (plates published separately: Koch 1883b).
KoCH, C. 1883b. Atlas von acht lithographischen Tafeln zur Monographie der Homalonotus-Arten des rheinischen Unterdevon. Abhandlungen zur geologischen Specialkarte von Preussen und den Thüringischen Staaten, Berlin 4(2), pls $1-8$.

KONINCK, L.G. DE 1841-1844. Déscription des animaux fossiles qui se trouvent dans le terrain Carbonifère de Belgique. 650 pp. Liège.

Korn, D. \& KLUG, C. 2002. Ammoneae Devonicae, 1-375. In RIEGraf, W. (ed.) Fossilium Catalogus I , Animalia 138. Backhuys, Leiden.

K Ǩíž, J. 2000. Lochkovian bivalves of Bohemian type from the eastern Anti-Atlas (Lower Devonian, Morocco). Senckenbergiana lethaea $80,485-523$.

KRÖGER, B. 2008. Nautiloids before and during the origin of ammonoids in a Siluro-Devonian section in the Tafilalt, Anti-Atlas, Morocco. Special Papers in Palaeontology 79, $1-112$.

KRÖGER, B., KLUG, C. \& MAPES, R. 2005. Soft-tissue attachments in orthocerid and bactritid cephalopods from the Early and Middle Devonian of Germany and Morocco. Acta Palaeontologica Polonica 50(2), 329-342.

LAfuste, J. \& PlusQuelleC, Y. 1976. Kerforneidictyum n. gen. (Tabulata, Dévonien) Morphologie et microstructure. Bulletin de la Société Géologique de France 18(6), 1699-1711.

LAFUSTE, J. \& PluSQUELLEC, Y. 1980. Les polypiers, Tabulata, 143-171. In PluSQuelleC, Y. (ed.) Les Schistes et Calcaires de l'Armorique (Dévonien inférieur, Massif armoricain); Sédimentologie - Paléontologie - Stratigraphie. Mémoires de la Société Géologique et Minéralogique de Bretagne 23.

LAfuste, J. \& PlusquelleC, Y. 1985. Structure et microstructure de quelques Micheliniidae et Michelinimorphes (Tabulata paléozoïques). Bulletin du Muséum d'Histoire naturelle de Paris, $4^{\text {ème }}$ sér. 7 C(1), 13-63.

LARDEUX, H. 1969. Les tentaculites d'Europe occidentale et d'Afrique du Nord. 238 pp. Cahiers de Paléontologie, Paris.

LE MAîTRE, D. 1952. La faune du Dévonien inférieur et moyen de la Saoura et de abords de l'Erg El Djemel (Sud-Oranais). Matériaux pour la carte géologique de l'Algérie, Paléontologie 12, 1-170.

LE MAÎTRE, D. 1954. Présence d'une microstructure de type acanthiné chez des Tabulés dévoniens du Sud-Oranais: Holacanthopora nov. gen. Comptes Rendus Académie des Sciences, Paris 238, 1668-1670.

Le Menn, J., Plusquellec, Y., Morzadec, P. \& LardeuX, H. 1976. Incursions hercynienne dans les faunes rhénanes du Dévonien inférieur de la rade de Brest (Massif armoricain). Palaeontographica A 153, 1-61.

Lubeseder, S., RedFern, J. \& BoutiB, L. 2009. Mixed siliciclastic-carbonate shelf sedimentation - Lower Devonian sequences of the SW Anti-Atlas, Morocco. Sedimentary Geology 215(1-4), 13-32. DOI 10.1016/j.sedgeo.2008.12.005

MASSA, D. 1965. Observations sur les séries siluro-dévoniennes des confins algéro-marocains du Sud. Notes et Mémoires, Compagnie Française des Pétroles 8, 1-188.

MAURER, H.F. 1874. Paläontologische Studien im Gebiete des 
rheinischen Devon. Neues Jahrbuch für Mineralogie, Geologie und Paläontologie 1875, 153-459.

MiLnE-EDWARDS, H. \& HAIME, J. 1850. A monograph of the British fossil corals. First part. Introduction; corals from the Tertiary and Cretaceous formations. Palaeontographical Society London 3, 2(7), 1-72.

MontesinOS, J.R. 1991. Ammonoideos de las Capas de Vañes (Formación Abadia) del Dominio Palentino (Palencia, NO de España). Cuaderno do Laboratorio Xeolóxico de Laxe 16, 193-201.

MonTESINOS, J.R. \& GARCIA-ALCALDE, J.L. 1996. An occurrence of the auguritid ammonoid Celaeceras in the Lower Devonian of northern Spain. Palaeontology 39(1), 149-155.

Montesinos, J.R. \& TRUYOLS-MAssoni, M. 1987. La Fauna de Anetoceras y el límite Zlichoviense-Dalejense en el Dominio Palentino (NO. de España). Cuaderno Laboratorio Xeolóxico de Coruña 11, 191-208.

MorzADEC, P. 2001. Les trilobites Asteropyginae du Dévonien de l'Anti-Atlas (Maroc). Palaeontographica A 262, 53-85.

NIKO, S. 1996. Pseudorthoceratid cephalopods from the Early Devonian Fukuji Formation of Gifu Prefecture, Central Japan. Transactions and Proceedings of the Palaeontological Society of Japan, New Series 181, 347-360.

NiKolAEVA, S.V. 2007. Discovery of Emsian Ammonoids in the Northern Caucasus. Paleontological Journal 41(5), 506-512. DOI 10.1134/S003103010705005X

OUANAIMI, H. \& LAZREQ, N. 2008. The "Rich" group of the Drâa Basin (Lower Devonian, Anti-Atlas, Morocco): an integrated sedimentary and tectonic approach, 467-482. In ENNIH, N. \& LIÉGEOIS, J.-P. (eds) The Boundaries of the West African Craton. Geological Society, London, Special Publications 297.

PANDOLFI, J.M. \& BURKE, C. 1989. Environmental distribution of colony growth form in the favositid Pleurodictyum americanum. Lethaia 22, 69-84.

DOI 10.1111/j.1502-3931.1989.tb01170.x

PetTer, G. 1959. Goniatites Dévoniennes du Sahara. Publications du Service de la Carte Géologique de l'Algérie, Nouvelle Série, Paléontologie 2, 1-313.

PHILLIPS, J. 1836. Illustrations of the geology of Yorkshire; or a description of the strata and organic remains; accompanied by a geological map, sections, and diagrams, and figures of the fossils. Part II. The Mountain Limestone District. 259 pp. John Murray, London.

PiQué, A. \& MiCHARD, A. 1989. Moroccan Hercynides: a synopsis. The Paleozoic sedimentary and tectonic evolution at the northern margin of West Africa. American Journal of Science 289, 286-330.

PLUSQUELLEC, Y. 1993. Un tabulé pleurodictyforme "biface" Procterodictyum n. gen. (Emsien du Nord Gondwana). Geologica et Palaeontologica 27, 103-121.

PLUSQUELLEC, Y. 2007. Histoire naturelle des pleurodictyformes (Cnidaria, Tabulata, Dévonien) du Massif armoricain et des régions maghrébo-européennes principalement. Mémoires de la Société Géologique et Minéralogique de Bretagne 32, 1-123.

Plusquellec, Y., FERNÁNDEZ-MARTíneZ, E., SANZ LóPEZ,
J., Soto, F., MAgrans, J. \& FerRer, E. 2007. Tabulate corals and stratigraphy of Lower Devonian and Mississippian rocks near Barcelona (Catalonian Coastal Ranges, Northeast Spain). Revista Española de paleontologia 22(2), 175-192.

Plusquellec, Y. \& FRANKE, C. 2010. Présence précoce du genre Kerforneidictyum représenté par K. oeslingensis n. sp. (Cnidaria, Tabulata) dans l'Emsien inférieur du Grand-Duché de Luxembourg. Ferrantia 58, 72-80.

PlusQuelleC, Y. \& HLADIL, J. 2001. Tabulate corals of Ibarmaghian affinities in the Upper Emsian of Bohemia. Geologica et Palaeontologica 35, 31-51.

PlusQuelleC, Y. \& JAHNKE, H. 1999. Les tabulés de l'Erbslochgrauwacke (Emsien inférieur du Kellerwald) et le problème des affinités paléogeographiques de l'allochtone "Giessen-Harz". Abhandlungen der Geologischen Bundesanstalt 54, 435-451.

PLUSQUELLEC, Y. \& SANDO, W.J. 1987. The microstructure of Michelinia meekana Girty, 1910. Journal of Paleontology 61(1), 10-13.

RAUP, D.M. \& MiCHELSON, A. 1965. Theoretical Morphology of the Coiled Shell. Science 147, 1294-1295.

DOI $10.1126 /$ science.147.3663.1294

RICHTER, R. 1855. Briefliche Mitteilung über Pleurodictyum an Herrn Beyrich. Zeitschrift der Deutschen Geologischen Gesellschaft 7, 559-566.

RUAN, Y.P. 1981. Devonian and earliest Carboniferous Ammonoids from Guangxi and Guizhou. Memoirs of the Nanjing Institute of Geology \& Paleontology 15, 1-152. [in Chinese]

RUAN, Y.P. 1988. Ammonoidea, 241-244. In HoU, H. \& WANG, S. (eds) Stratigraphy of China No. 7 - The Devonian System of China. 344 pp. Geological Publishing House, Beijing.

RUAN, Y.P. 1996. Zonation and distribution of the early Devonian primitive ammonoids in South China, 104-112. In WANG, H.-Z. \& WANG, X.-L. (eds) Centennial Memorial Volume of Prof. Sun Yunzhu, Palaeontology and Stratigraphy. China University of Geosciences Press.

RUAN, Y.P. \& HE, G. 1974. Devonian Ammonoids, 238-239. In NANJing Institute of GEOLOGY AND PALEONTOLOGY (ed.) A handbook of the stratigraphy and paleontology in Southwest China. Academia Sinica, Nanjing. [in Chinese]

RUAN, Y.P. \& MU, D.C. 1989. Devonian Tentaculitoids from Guangxi. Memoirs of Nanjing Institute of Geology and Palaeontology 26, 1-209. [in Chinese]

RUZHENCEV, V.E. 1957. Filogeneticheskaya sistema paleozoyskikh ammonoidey. Byulleten' Moskovskogo obshchestva ispytately prirody, novaya seriya, Otdel geologicheskiy 31(2), 49-64.

SANDBERGER, G. \& SANDBERGER, F. 1849-1856. Die Versteinerungen des rheinischen Schichtensystems in Nassau. 564 pp. Kreidel und Niedner Verlagsbuchhandlung, Wiesbaden.

SCHINDEWOLF, O.H. 1934. Zur Stammesgeschichte der Cephalopoden. Jahrbuch der Preussischen Geologischen Landesanstalt 55, 258-283.

SCHINDEWOLF, O.H. 1959. Würmer und Korallen als Synöken. Zur Kenntnis der Systeme Aspidosiphon/Heteropsammia und 
Hicetes/Pleurodictyum. Abhandlungen der Akademie der Wissenschaften und Literatur, mathematisch-naturwissenschaftliche Klasse 1958(6), 259-328.

SCHRAUT, G. 2000. Trilobiten aus dem Unter-Devon des südöstlichen Anti-Atlas, Süd-Marokko. Senckenbergiana lethaea 79, 361-433.

SERVICE GÉOlOGIQUe DU MAROC 1971. Royaume du Maroc, Ministère de l'Énergie et des Mines, Direction de la Géologie. Carte Géologique des Plaines du Dra au Sud de l'Anti-Atlas Central. Agadir Tissint - Qued Zemoul. 1/200000. Éditions du Service Géologique du Maroc, Notes et Mémoires 219.

SERVICE GÉOlOGIQUe DU MAROC 1985. Royaume du Maroc, Ministère de l'Énergie et des Mines, Direction de la Géologie, Carte Géologique du Maroc 1/1000000. Éditions du Service Géologique du Maroc, Notes et Mémoires 260.

SHEN, Y.T. 1975. Discovery of primitive ammonoids from Nandan of Guangxi and its stratigraphical significance. Professional Papers in Stratigraphy and Paleontology 1, 86-104. [in Chinese]

STEININGER, J. 1853. Geognostische Beschreibung der Eifel. 153 pp. Lintz, Trier.

SteinMAnN, G. \& DÖDERLEIN, L. 1890. Elemente der Paläontologie. 848 pp. Engelmann, Leipzig.

TEICHERT, C. 1948. Middle Devonian goniatites from the Buchan District, Victoria. Journal of Paleontology 22, 60-67.

Termier, G. \& TERMIER, H. 1950a. Paléontologie Marocaine. II. Invertébrés de l'ére Primaire. Fascicule III. Mollusques. Notes et Mémoires du Service Géologique 78, 1-246.
Termier, G. \& Termier, H. 1950b. Paléontologie Marocaine. II. Invertébrés de l'ére Primaire. Fascicule IV. Annélides, arthropodes, échinodermes, conularides et graptolithes. Notes et Mémoires du Service Géologique 79, 1-279.

YATSKOV, S.V. 1990. O drevneyshem semeystve ammonoidey Anetoceratidae. Paleontologicheskiy Zhurnal 1990(3), $25-32$.

YATSKOV, S.V. 1994. Devonian ammonoid zonation on Novaya Zemlya. Newsletters on Stratigraphy 30(3), 167-182.

YU, C.M. \& RUAN, Y.P. 1988. Proposal and comment on the definition of the Emsian, 449-468. In MCMiLlan, N.J., EMBRY, A.F. \& GLASS, D.J. (eds) Devonian of the world, Vol. III: Paleoecology and biostratigraphy. Canadian Society of Petroleum Geologists Memoir 14, 179-191.

WAAGEN, W.H. \& WENTZEL, J. 1886. Salt Range fossils, vol. 1, Productus limestone fossils; 6, Coelenterata. Memoirs of the Geological Survey of India 13, 835-924.

WEBB, G.E. 1993. Skeletal microstructure and mode of attachment in Palaeacis species (Anthozoa: Tabulata) from the Mississippian and Pensylvanian of Eastern Oklahoma and Northwestern Arkansas. Journal of Paleontology 67(2), 167-178.

WRIGHT, A.J. \& FLORY, R.A. 1980. A new early Devonian tabulate coral from the Mount Frome Limestone, near Mudgee, New South Wales. Proceeding of the Linnean Society of New South Wales 104(3), 211-219.

ZITTEL, K.A. VON 1881-1885. Handbuch der Palceontologie. I. Abtheilung. Palceozoologie. II. Band. Mollusca und Arthropoda. 893 pp. Oldenbourg, Leipzig. 